STUDIES ON CRIME

AND JUSTICE

A SERIES FROM

THE RESEARCH

AND DOCUMENTATION

CENTRE

\title{
BETWEEN \\ PROHIBITION \\ AND LEGALIZATION \\ THE DUTCH \\ EXPERIMENT \\ IN DRUG POLICY
}

EDITED BY ED. LEUW AND I. HAEN MARSHALL

KUGLER PUBLICATIONS

AMSTERDAM / NEW YORK 
Between prohibition and legalization : the Dutch experiment in drug policy / edited by E. Leuw and I. Haen Marshall.

p. cm. -- (Studies on crime and justice)

Includes bibliographical references.

ISBN 90-6299-103-3

1. Narcotics, Control of--Netherlands. 2. Drug abuse-

-Netherlands--Prevention. I. Leuw, Ed. II. Haen Marshall,

I. (Ineke) III. Series.

HV5840.N4B48 1994

363.4'5'09492--dc20

ISBN 90-6299-103-3

Distributors:

For the U.S.A. and Canada:

Kugler Publications

P.O. Box 1498

New York, NY 10009-9998

Telefax (+212) 477-0181

For all other countries:

Kugler Publications

P.O. Box 11188

1001 GD Amsterdam, The Netherlands

Telefax $(+31.20)$ 638-0524

CCopyright 1994 Kugler Publications

All rights reserved. No part of this book may be translated or reproduced in any form by print, photoprint, microfilm, or any other means without prior written permission of the publisher. 


\section{CONTENTS}

Introduction

vii

\section{Part I: IDEOLOGICAL FOUNDATIONS OF "PRAGMATISM"}

I. A short history of drugs in the Netherlands by Marcel de Kort

II. Initial construction and development of the official Dutch drug policy

by Ed. Leuw

III. Enforcing drug laws in the Netherlands by Jos Silvis

IV. Drugs as a public health problem - assistance and treatment by Leon Wever

V. Dutch prison drug policy - towards an intermediate connection

by L.H. Erkelens and V.C.M. van Alem

Part II: LIMITED PROBLEMS AND MODERATE MEASURES

VI. The development of contemporary drug problems by Koert Swierstra

VII. Drug tourists and drug refugees by Dirk J. Korf

VIII. Snacks, sex and smack - the ecology of the drug trade in the inner city of Amsterdam by Frank van Gemert and Hans Verbraeck

IX. The development of a "legal" consumers' market for cannabis - the "coffee shop" phenomenon by A.C.M. Jansen

$X$. The drug-related crime project in the city of Rotterdam by Bert Bieleman and Jolt Bosma 
Part III: INTERNATIONAL AND SUPRANATIONAL DIMENSIONS

XI. Drug prevention in the Netherlands - a low-key approach by Ineke Haen Marshall and Chris E. Marshall

XII. Legalization, decriminalization and the reduction of crime by $M$. Grapendaal, Ed. Leuw and $H$. Nelen

XIII. The future of the Dutch model in the context of the war on drugs

by Tom Blom and Hans van Mastrigt

XIV. An economic view on Dutch drugs policy by D.J. Kraan

$\mathrm{XV}$. Is Dutch drug policy an example to the world? by C.D. Kaplan, D.J. Haanraadts, H.J. van Vliet and J.P. Grund 


\section{INTRODUCTION}

In a period of two decades Dutch drug policy has evolved in partial opposition to the internationally dominant ideology of prohibitionism. The "normalizing" home policy, together with the compliance to law enforcement in the international arena, make up a rather complicated and ambivalent Dutch position in drug policy. The Dutch drug policy is fully in line with the international control practices against wholesale drug trafficking. As regards its social drug policy, however, it has become a rare dissenter within an increasingly unifying and compelling international drug policy context. This book gives an account of the national Dutch drug control strategy.

The course, the practice and the rhetorics of any drug policy are determined by its major theoretical premises. It is the final ideological position of the Dutch "pragmatic" or "non-moralistic" drug policy, that problems of deviant drug taking and drug selling are deeply and inescapably part of the society in which they occur. This stands in contrast to the more traditional prohibitionist notion which puts primary blame on users and sellers of illegal substances.

The assertion of "user accountability" has followed logically from the American prohibitionist "war on drugs". It assumes that drugs and addiction form an evil in itself, which can be purged from society by deterrence and by promoting total abstinence. The Dutch understanding of the social liability of illegal and addictive drugs is rather less straightforward. It painstakingly balances between the reciprocal notions of freedom and responsibility. This involves, on the one hand, the personal freedom of the individual (i.e., the right to self-determination) to use drugs and even to be addicted; on the other hand, it involves the personal responsibility of drug users for their own (mental) health and their own social behavior (criminality included).

In the Dutch view, then, accountability for the existence of drug and addiction problems is shared by drug users/dealers and society. This means that the responsibility of users of illegal drugs is mitigated by society's responsibility for criminalizing drugs and for the existence of social conditions that make using and selling illegal drugs a functional and rewarding practice for relatively large segments of the population. More specifically, within the framework of Dutch drug policy, drug users are not held accountable for the social marginality, deterioration and de- 
gradation that accompanies deviant addiction. These adversities are understood as consequences of society's choice to prohibit (the use of) certain psycho-active substances.

Criminalization of "drugs" is a public means by which society demarcates conventionality. "Drug accountability", for all but the most direct and primary psycho-pharmacological drug effects, should consequently be given to conventional society. More than anything else, this basic understanding may explain the course of Dutch drug policy towards harm reduction in the case of hard drugs and (de facto) "legalization" in the case of soft drugs (marihuana and hashish). This has been the consistent course since the adoption of the Revised Opium Act in 1976.

Perhaps more than with any other social problem, the extent and quality of drug problems are a reflection of a particular society's moral priorities and preoccupations, its political processes, the (in)equalities of its distribution of wealth and welfare among (ethnic) classes and the integrative (in)adequacies of its culture. Illegal drug taking, addiction and the viability of the illegal drugs trade are all symptoms and logical consequences of a national social-economic and cultural order. Granted, to a certain extent, the (illegal) drug problem may legitimately be perceived as a threat to a nation's health, its security or its young generation. But it would be a gross distortion of the nature of drug problems to conceive of them as alien and evil menaces forced upon an innocent society. Within Dutch social history it has become almost a truism that the "innate" alcoholism among Dutch working classes earlier this century could be attributed to their poverty and political powerlessness. Some decades later, in a more equitable society, alcoholism has become a normal and equally distributed (public) health liability (Gerritsen 1993). In similar vein, few people in our part of the world would doubt that the extent of problematic alcohol use in present Russia is a symptom rather than a cause of a stagnating society.

Consistent with this view, Dutch drug ideology has rejected the idea that present day drug addiction and drug trafficking, with its heavy concentration in socially deprived and culturally alienated population groups, could (or even should) be eradicated without reconsidering society's social-economic and cultural order. But obviously, staging a socio-cultural revolution in order to eliminate drug addiction is just as futile as staging a "war on drugs" in a society which gives abundant "good reasons" and opportunities for using drugs, abusing drugs and earning money with selling drugs. 
Instead of staging a moral crusade for a "drug-free society", the Dutch drug policy model has favored more mundane objectives such as de-escalation and normalization of drug problems. During the last twenty years a rather coherent pattern of drug political instruments and practices has been developed to further this basic goal. They will be described and explained in the various chapters.

In line with the ideological presumptions sketched above, Dutch drug policy is firmly entrenched in social scientific knowledge. Drug control measures in the Netherlands are largely executed by the means of social work and welfare agencies. The doctrines of medical practice and legal deterrence are certainly not absent in the Dutch drug control system, but they are of less central importance than in more traditional modes of drug policy. Problematic drug use is accepted as an inevitable, but limited and manageable social and (public) health problem of modern society.

Law enforcement is viewed as an unsuitable means to regulate the demand side of drugs, as this instrument for control tends to aggravate rather than alleviate the public health and public order problems of illegal drug use. While using hard drugs and being in possession of these for one's own use are legally proscribed, in practice the Dutch criminal justice system does not intervene here. Employing law enforcement is restricted to the higher levels of the illegal drugs trade. The predominance of the social scientific view is also reflected in a relatively low level of medicalization of drug problems. Using drugs is primarily understood not as a disease, but as normally motivated (but often unwise) behavior, fitting in a certain lifestyle, personal development and social conditions. Accordingly "curing to abstinence" or primary prevention of drug use are not the central objectives of Dutch social drug policy. Instead of minimizing the number of users and the extent of illegal drug use, Dutch drug policy is first and foremost concerned with reducing the risks and hazards of drug taking.

Harm reduction is the core concept. It is implemented by extensive low level and non-conditional methadone prescription, social-medical assistance for drug users, large-scale free needle exchange programs, and the pragmatic acceptance of a number of "free zones" where the consumers drug market is left relatively undisturbed.

In a more general sense the principle of harm reduction is also implemented by abstaining from state interference with illegal but non-deviant drug use (i.e., kinds of illegal drug use which are not heavily frowned upon, or considered highly problematic by large parts of society). Although the recent increase of cultivation and commercialization of soft drugs has created (mainly drug diplomatic) policy concerns, Dutch 
society seems to have moved beyond the point that the repression and stigmatization of hashish and marihuana can be justified. Using soft drugs has in the course of two decades of "normalizing" drug policy evolved into a legitimate private choice. Use may be a possible concern for parents and educators, but no longer a credible case for state interference. To a lesser extent the same may apply to the fashionable recreational and largely non-problematic use of XTC or cocaine (Cohen 1990).

The ideological key concept of "normalization" deserves more clarification. Conceiving of the drug problem as a social problem in the true sense of the word implies that a "solution" can be achieved by gradually reversing the social construction of the drug problem, through a process of reduction of signficance and (moral) interest. "Normalizing" simply means a de-escalation of the social (drugs) conflict, in which both the socially added attractions and harmfulness of illegal substances are reduced. Drugs may inevitably produce a "funny" or even pleasurable feeling in the head. But, ideally, that should be their only inevitable consequence. Their economic attractions, the glorious defiance, the identity and (deviant) sense to life that illegal drugs confer are solely produced by repressive and stigmatizing social control. In this sense normalisation is synonymous to decriminalization.

Normalization not only requires the reduction of secondary harm and attractions of illegal substances, it also implies that the social and political rewards of the drug prohibition system itself are to be discarded. Under the conditions of normalization, no extrinsic moral or political interests should be served with the regulation of psycho-active substances. This is a far cry from reality under the present conditions of prohibition. In fact, the secondary moral and political rewards of drug prohibition probably offer the best explanation of the persistence of a social control system which so blatantly fails to achieve its professed aims. Prohibition is a success, not because it helps to limit the public health and security problems of society, but because it offers substantial and highly valued moral, political, economical and social rewards.

Political careers and professional careers are made through the drug control system, even those of the sociological detractors and castigators of the system. It helps to boost politicians' popularity by providing them with uncontroversial and gratuitous rallying themes and election platforms. It helps to simplify and neutralize the structural and cultural strains within society. Intractable adversities such as marginality, deprivation, alienation and ethnic tensions can conveniently be attributed to drugs as an alien evil. The drug problem even allows these adversities 
to be attributed to a lack of willpower and morality within the most deprived population groups, where, invariably, drug addiction has settled (Musto 1973; Scheerer 1993; Duster 1970; Lidz et al. 1980). Of course the Dutch "pragmatic" drug policy has not completely exempted itself from these self-deceiving lures. But, as will be explained in This Volume, furthering moralistic and political aims by rallying on the drugs issue is certainly less feasible within the framework of "pragmatic" drug policy.

The selection of the chapters in this book bear witness to the fact that the Netherlands has a valuable and varied empirical research tradition aimed at careful documentation of drug-related issues. Typically, the studies in this book combine careful empirical description with theoretical analysis. Not only is most research described in this collection theoretically grounded, it also represent a creative integration of different research methods (secondary analysis of available data, observations, ethnographic accounts, repeated in-depth interviews). Another common theme in the works presented here is that all the researchers, some more explicitly than others, try to challenge common myths and misperceptions about drugs and the effects of drug policy.

"All drugs are legal in Holland..." "In Amsterdam, drug-related crime is rampant..." "The Dutch have lost all control over using and dealing drugs..." - these are but a few examples of the incorrect or incomplete beliefs about Dutch drug policy often expressed by foreigners. One of the primary purposes of this book is to debunk some of these myths by providing a complete and in-depth description of the facts about drug policy in the Netherlands. To this end, the chapters in the Part I (Chapters 1 through 5) provide a detailed description of the legal, social, and philosophical foundations of the current pragmatic Dutch drug policy. A major theme of the book is how and why Dutch drug policy is so different from that of other European countries and the U.S. The first two chapters of Part I address this question by providing the historical and socio-political background of current Dutch drug legislation and policy. De Kort (Chapter 1) traces the development of Dutch drug policy back to the government's economic interests in the drug trade involving the Dutch colonies in the 19th century and its resultant reluctant enforcement of the early international drug treaties. He explains the Dutch emphasis on the medical-social care of users and prevention by referring to specific national political, social and cultural circumstances (i.e., drug use remained limited to isolated groups, influential role of medical profession on policy, lack of a moral entrepreneur, and integration of the youth culture 
into the social and political mainstream). In Chapter 2, Leuw zeros in on the history of the political and cultural forces involved in the centerpiece of Dutch drug legislation, the 1976 Revised Opium Act and the crucial role of two expert committees in formulating policy. He emphasizes how in the Netherlands the drug problem has not been a confrontational issue between moral/political right and moral/political left, but rather has gone through a process of de-escalating significance, very different from countries like the U.S. and Germany. Modern Dutch drug policy is based on two principles: combatting large-scale drug trafficking (through law enforcement) and prevention and assistance to the drug user (through public health). Silvis (Chapter 3) gives an overview of the legal principles behind drug enforcement in the Netherlands; he highlights the role of the "principle of expediency" which provides the legal latitude to develop policy guidelines not to enforce particular drug law violations (i.e., those involving users and small-scale dealing). Silvis also shows how the Netherlands has not remained immune to the erosion of due process protections often associated with drug enforcement. The Dutch view drugs primarily as a public health problem, and only secondarily as a criminal justice problem. Wever (Chapter 4) describes the public health approach to drugs, both in terms of its philosophy (with as key concepts normalization, risk reduction, and prevention) and its practical operationalization in treatment and services. Both Silvis and Wever speculate about the effects of international forces on drug policy. The discussion of the ideological foundations of Dutch pragmatism in Part I is completed by Erkelens and Van Alem (Chapter 5) in their analysis of the development and state-of-the-art of Dutch correctional policy. They show how this policy has developed within the changing perspectives of general criminal justice policy and the general drugs and crime problem in Dutch society. Of particular interest is their discussion of the so-called "drug-free units" (DFUs) in Dutch prisons, which in the view of many exemplify the Dutch pragmatic approach to drugs.

Different from the United States, where drugs are considered a problem of utmost urgency, the Dutch do not view drugs as a tremendously pressing problem. Consistent with this view, Dutch drug policy is best characterized as low key and minimalist. "Moderation" is the thread connecting the chapters in Part II of the book (Chapters 6 through 10). Swierstra (Chapter 6) chronicles the development of drug problems in the Netherlands over the last two decades. In addition to describing epidemiological developments in drug use, he asks whether Dutch drug use careers differ from those observed in other countries; and, if so, if these 
differences reflect the particular nature of Dutch drug policy. He bases his observations on the results of two empirical studies of the careers of hard drug users, and he concludes that the patterns and careers have changed over time, reflecting social, political and drug policy changes. He concedes that pragmatic Dutch drug policy has facilitated experimentation with drugs, and that methadone maintenance, although it may keep people addicted for longer periods of time, keeps people more socially integrated. Korf (Chapter 7) uses a field study of 382 drug tourists to study why foreign drug users come (and stay) in Amsterdam, how they generate their income, and what - if any - are the effects of the Dutch policy of "discouragement"? Van Gemert and Verbraeck's (Chapter 8) ethnographic account of two decades of drug dealing and use also is based on Amsterdam observations, with a particular focus on how the culture of the Amsterdam inner city provides a fertile and hospitable environment for drug users and drug dealers. Their account illustrates the important fact that one can only understand the nature of the local "drugs scene" against the backdrop of the cultural and economic context of the neighborhood. The chapter further shows that a sometimes tense, but generally peaceful cohabitation of the drug subculture with traditionally deviant and more conventional city life is feasible. Amsterdam is also the focus of Jansen's description (based largely on personal observations of transactions) of the "coffee shop" phenomenon (Chapter 9). Coffee shops are perhaps the most well-known examples of "liberal" drug policy known to foreigners; Jansen uses his description to show that Dutch society has successfully integrated soft drugs into mainstream society. Part II concludes the description of the restrained Dutch approach to drugs with Bieleman and Bosma's discussion (in Chapter 10) of the Rotterdam Drug-Related Crime Project, an experimental program emphasizing cooperation between local city government, the Prosecutor's Office, police, and drug assistance agencies, aiming to prevent drug-related criminality. Within a three-year time period (1988-1990), four (smallscale) DRC programs were implemented: a research study describing the extent and nature of the Rotterdam drug-using population, a work project aimed at the reintegration of addicts into society, a "target hardening" project to reduce drug-related property crime in parking garages; and a shelter for addicts near the Central Station aiming at the reduction of nuisance associated with the concentration of drug addicts in that area. Although not successful by all measures, Bieleman and Bosma document several accomplishments of this pilot project. 
Most of the chapters of the book touch, in one way or another, on one of three key questions: (1) how is Dutch drug policy different from that of other countries; (2) how is the increasing internationalization of the world going to have an impact on Dutch drug policy, and (3) is there anything in Dutch drug policy that may be transferred to other nations. Part III makes these questions its central concern. First, in Chapter 11, Marshall and Marshall examine the philosophy of drug prevention as well as the major types of drug prevention programs in the Netherlands. Within the perspective of "normalization" drugs are a normal health education issue which, relative to for instance alcohol use or safe sexual practices, is of minor importance for general (young) population groups. Dutch drug prevention is contrasted with the U.S. as low-key and minimal and less likely to make use of fear arousal and/or moral appeals. Grapendaal, Leuw and Nelen (Chapter 12) present a field ethnographic study of Amsterdam to assess arguments pro and contra legalization and decriminalization. The drug legalization debate is one that crosses national boundaries and often manages to ignite international consternation among government officials and policy makers of the highest level. Grapendaal and co-workers' study is based on repeated interviews of a sample of Amsterdam opiate addicts about their drug taking and economic behavior over a period of 13 months; they examine the role of drugs in the initiation of the criminal career, the effect of methadone maintenance on property crime, and the (in)elasticity of demand. They interpret their data in a deviant career perspective: people who are attracted to drugs are looking not only for dope, but also for illegality. Blom and Van Mastrigt (Chapter 13) describe several international developments, more specifically those related to the ongoing process of European unification, which might affect the Dutch model of drug control. They discuss Dutch drug policy as it has developed since the midseventies in the context of the foundation of national and international developments in drug policy, the Single Convention. They do an admirable job in describing the rather chaotic world of international drug control bodies in Europe (including the United Nations). They speculate about the likelihood that the Dutch model will survive in the international War on Drugs, using relevant domestic developments in the Netherlands. Kraan (Chapter 14) analyzes Dutch drug policy from an economic perspective, employing a "public choice" approach to analyze the regulation of markets and the provision of services with regard to cannabis, cocaine, and heroin. His comparison of the relative importance of health care versus law enforcement costs between the U.S. and the Netherlands illustrates the utility of this model as a way to operationalize 
the philosophical principles underlying different social policies. This chapter suggests that the Dutch policy model allows better returns for substantially less public expenses. Consistent with the title of the book, Kaplan, Haanraadts, Van Vliet and Grund (Chapter 15) conceive of Dutch drugs policy as an "experiment" in the shift from a "more of the same" adaptation strategy to a "different goals" strategy. This concluding chapter represents an ambitious attempt to provide a pragmatic answer to the question of whether Dutch drug policy may be used as an example for other countries by identifying the "manageable bits" which are transferable to other countries. The authors argue that Dutch society presents a compact adaptation of broad socio-historical processes which all modern societies are now undergoing; Dutch society is an example of the new and innovative well-being state (De Swaan 1988). The emotional and cultural conditions for the technology transfer of Dutch drug policy are becoming more widespread. In view of the fact that Dutch drug policy is, by most measures, more humane and less costly than that of many other countries, it is appropriate to conclude this book with the optimistic note that Dutch drug policy, in the final analysis, although in many ways unique to the Netherlands, does have implications beyond Dutch national boundaries.

\section{References}

Cohen, P.: Drugs as a Social Construct. Utrecht: Elinkwijk, 1990

Duster, T.: The Legalisation of Morality: Law, Drugs and Moral Judgement. New York: Free Press, 1970

De Swaan, A.: In Care of the State: Health Care, Education and Welfare in Europe and the USA in the Modern Era. Cambridge: Polity Press, 1988

Gerritsen, J.: De Politieke Economie van de Roes: de Ontwikkeling van Reguleringsregimes voor Alcohol en Opiaten. Amsterdam: Amsterdam University Press, 1993

Lidz, C.M., Walker, A.L. and Gould, L.C.: Drugs, Deviance and Morality. Beverly Hills: Sage Publications, 1980

Musto, D.F.: The American Disease: Origins of Narcotic Control. New Haven: Yale University Press, 1973

Scheerer, S.: Political ideologies and drug policy. European Journal on Criminal Policy and Research Vol. 1, No. 1, 1993 
PART I

IDEOLOGICAL FOUNDATIONS

OF "PRAGMATISM" 


\title{
I. A SHORT HISTORY OF DRUGS IN THE NETHERLANDS
}

\author{
Marcel de Kort
}

\section{Introduction}

Dutch drug policy deviates substantially from drug policies in most other countries. It is not surprising, then, that Dutch drug policy has often met with severe criticism from abroad. Criticism from foreigners has become more pronounced during the last decade. For example, critics in the United States have objected to the low-threshold methadone programs and needle-exchange programs; Germany and Sweden have strongly criticized the decriminalization of the use of cannabis. ${ }^{1}$ It is such controversial aspects - the attention to the medical and social care of drug users and the decriminalization of marihuana - which form the "deviant" core of Dutch drug policy.

If indeed Dutch drug policy deviates so much from drug policies in other countries, an interesting question presents itself: How can we explain the development of this unique Dutch way of dealing with drugs? How was the historical development of the Netherlands with regard to drug policy different from, say, the United States and Great Britain? This chapter attempts to answer this question as follows. In the first section, I provide a brief description of the highlights of the developments in Dutch drug policy: 19th century drug use, Dutch interests in the production and sale of drugs, the Dutch position in international opium conferences, the 1919 Opium Act and developments after the Second World War. In the second part of this chapter, I discuss the political and social conditions in the Netherlands which provided the foundation for the development of this much criticized policy. Illuminating in this respect is a comparison with the developments in the United States and England. The present chapter's emphasis is predominantly on the developments prior to the mid 1970 s.

\section{Self-medication and medicine in the nineteenth century}

In the 19th century, quackery and popular healing had a dominant position in health care. Self-medication was so popular that around the end 
of the 19th century a large part of the population had never even visited a physician. The cause of this low level of consultation of physicians should not be located in a shortage of physicians or poor social-economic conditions of the Dutch population. Modern medical care was readily available through the system of poor relief or sick funds. In addition, there was an abundance of recognized medical doctors during the second half of the 19th century.

According to Verdoorn (1981), 19th century Dutch society knew two types of medicine: the "primitive-traditional" and the "rational-scientific". These two types were not integrated, but co-existed independently from one another. Based on popular healing practices, the believers in "primitive-traditional" healing rejected elements of modern medicine, such as physicians, hospitals and midwives. Those patients who did visit physicians accepted the modern "rational-scientific" way of thinking. These two separate groups, with their very own cultural pattern with regard to illness and health, existed side by side until around 1880 when the integration of these patterns begun. The gradual integration of "primitive-traditional" and "rational-scientific" approaches to healing continued well into the 20th century. Opiates played an important role in "primitive-traditional" medicine. Nineteenth-century books about popular healing contain many prescriptions with opiates. For example, one could fight toothache by placing a piece of opium in the hollow tooth or by rinsing one's mouth with opium solvent; hemorrhoids would disappear through the use of a poppy oil enema (Osiander 1854). Poppy oil or syrup could cure many ailments and was also used to keep children quiet and relaxed. The use of poppy syrup as a baby "pacifier" was the best-known and most infamous application of this drug until well into the 20th century. After a spoonful of poppy syrup, the baby would stop crying and quietly fall asleep. In 1854, giving poppy syrup to babies was still considered a "good habit". Half a century later, people began to reject it due to the risk of poisoning the children through an overdose. In the middle of the 19th century, however, the use of opiates was not yet taboo. The different remedies were readily available and cheap.

In the second half of the 19th century, a large variety of patent medicines (usually referred to as "specialités" or "specialties"), often containing opium, cocaine or marihuana, became part of "primitive-traditional" medicine. Numerous types with exotic names and helpful for virtually all ailments became available. From 1875 on, it was particularly the medicines containing cocaine which became popular, such as Vin de coca du Perou, Professor Dr. Sampson's coca preparations and the coca preparations of Doctor Jose Alvarez. 
Opiates were also used frequently in the practice of "rational-scientific" medicine. Opium was virtually the only adequate remedy with a pain-killing effect. In the 19th century other pain killers such as aspirin were not yet available. Thus, physicians of that period did not have any alternative pain killers, had little understanding of the harmful effects associated with drugs, and freely prescribed drugs to their patients. In the middle of the 19th century, members of the medical profession were mostly positive about drugs: morphine was viewed as having no harmful side-effects and one was enthusiastic about Dover's powder, a "specialty" containing opium. Morphine, in particular, was used frequently. As early as the beginning of the 19th century, a German by the name of Sertuner managed to extract morphine from opium, but morphine did not become very popular until the invention of the hypodermic needle 50 years later. Injection of morphine by hypodermic needle was an application of "rational-scientific" medicine. Whenever they saw a need, physicians would inject large quantities of morphine in their patients for a variety of reasons, thereby creating a new group of addicts. In fact, physicians created a new disease, which may be characterized as iatrogenic dependency.

About ten years after the hypodermic needle was first used, physicians concluded that morphine was addictive. They called this addiction "hunger" or "desire" for morphine, "morphinomania" or "morphinism". Initially, French and German doctors spearheaded the study of the addictive effect of morphine; however, soon afterwards research on "morphinism" was done in large parts of Europe and the United States. ${ }^{2}$

In Dutch medical publications there were mostly references to foreign research, with the added note that "morphinism" was more of a problem in countries other than the Netherlands. It is possible that there were relatively fewer visible morphine addicts in the Netherlands than, for example, in Germany, France and the United States. Because of historical developments such as the French-German War (1870) and the American Civil War (1861-1865), the number of addicts in Germany, France and the US experienced an explosive growth. The rise of this "soldier's disease" stimulated the field of medicine in these countries to conduct research on the addictive qualities of morphine. The Netherlands, on the other hand, was not involved in a war during the second half of the 19th century, which made morphine addiction there a less noteworthy phenomenon than in other countries. Another possible explanation for these international differences in connection with morphine addiction may be found in the more prominent role of popular healing in the Netherlands as compared to other Western European countries and the US. Due to the 
importance of "primitive-traditional" medicine in the Netherlands, fewer people were at risk of developing an iatrogenic addiction through "rational-scientific" medicine (i.e., hypodermic needle); rather, people could ingest liquid laudanum or a "specialty" containing opium.

In 1886, a dissertation entitled Alcoholism, Morphinism and Chloralism was published, the only extensive Dutch study of this topic in the 19th century. Broers, the author of this dissertation, concluded that this morphine "disease" was spreading in all countries, including the Netherlands, at a frightening speed. Broers based his conclusions primarily on information extracted from foreign publications. He managed to introduce only a few of his own patients as "Dutch morphinists". It is impossible to provide a reliable estimate of the total number of "morphinists" living in the Netherlands during that period. There simply are no statistics and extensive studies. However, we do know that around the turn of the century, articles on addiction to morphine and cocaine appeared regularly, primarily in the Dutch Journal of Medicine and the Pharmaceutical Weekly.

Around 1880 , Dutch medical specialists began to examine cocaine more closely, as a result of the spread of "cocainism" in the Netherlands. Gradually, one started to distinguish between the use of drugs for medicinal or recreational purposes. If prescribed by the physician, opiates and cocaine were viewed as beneficial. On the other hand, the same drugs in the hands of the lay public were considered stimulants and thus harmful. In effect, physicians and pharmacists were simply attempting to obtain a monopoly on the prescription, administration and supply of drugs. This trend paralleled the professionalization of the medical and paramedical occupations taking place during that time.

The last decades of the 19th century thus witnessed a re-definition of drug use as problematic by the medical profession. After the medical profession had put a claim on opiates and cocaine, an "attack" on self-medication became inevitable. The "specialty industry", with its heavy reliance on drugs, was a thorn in the side of official medicine. Spearheaded by the Union against Quackery, physicians who were eager to professionalize their occupation initiated an offensive against the competition. Indeed, around 1900, the use of drugs had become a problem for the medical profession enviously eying the unrestrained sale of opiate-based or cocaine-based specialties.

The 19th century drug history of the Netherlands is not very different from what took place in other Western countries. In the United States, England, France and Germany, opiates and coca(ine) also played an important role, both in self-medication and in official medicine. ${ }^{3}$ There was 
a considerable volume of concerned writing about addiction to morphine and cocaine in these countries. The Netherlands differed from the US and other Western European countries in that it did not have any addicted soldiers and there was hardly any scientific research on the nature and dimensions of the addiction. However, both medical and pharmaceutical sources strongly suggest that the Netherlands certainly was not a drugfree country at that time.

\section{The Netherlands Indies, drug production and trade}

It was not until the end of the 19th century that the Netherlands became concerned with the use of drugs as a stimulant. This concern must be understood in the historical context of the Dutch government's role in the production and trade of drugs, particularly in its colonies. In the former Dutch colony of the Netherlands Indies, recreative use of opium had been experienced for a much longer time. Indeed, the smoking of opium by the local population had resulted in huge profits for the Dutch for centuries. The Dutch used a system of "opium leasing" - that is, the government leased the right to sell opium to the highest bidder. Dutch ships transported the opium from Turkey and Bengal to the Malay Archipelago, where distribution was left primarily to Chinese opium leaseholders. According to Vanvugt (1985), the Dutch position regarding the trading and consumption of opium was determined by the financial interest of this trade for the national treasury. Colonial profits were, to a large degree, dependent upon opium profits. Between 1834 and 1875, the net opium profit was 3,369 million guilders (about 2,000 million dollars); between 1876 and 1915, the profits from opium were 7,033 million guilders (about 3,500 million dollars). Between 1816 and 1915 the total net profit from opium constituted approximately ten percent of the total income from the colonies for the Dutch treasury. By the end of the 19th century, when it became apparent that the profits from opium leasing were declining, the government decided to implement a state monopoly on the sale and distribution of opium in the Netherlands Indies. This state monopoly was referred to as the "regie-system".

The debate accompanying the transition from the leasing system to the state monopoly resulted in an enormous volume of books, flyers and pamphlets about opium. Typically, this literature was written in a polemic style and focused on three themes: (1) the problems of opium smuggling in the Dutch East Indies; (2) the possible harmful effects of opium use; and (3) the transition from the leasing system to the state monopoly. Financial considerations played an important role: for each proposed 
change in policy the financial consequences for the state's treasury were closely scrutinized. There was no question that measures should be taken against smuggling practices which would cut tax revenues. The advantages of a state monopoly were stressed heavily in this literature; a state monopoly would inhibit smuggling because the (legal) state opium with its own packaging would be clearly distinguishable from the (illegal) smuggler's opium. Second, a state monopoly would mean higher profits, in view of the fact that income from opium leasing had declined substantially by the end of the 19th century. Finally, it was argued that it would be easier to reduce the number of opium smokers by a state monopoly than by any other system. This last advantage was considered especially important by a group of authors who emphasized the harmful effects of the smoking of opium and who viewed it as the responsibility of the Dutch to decrease drug use.

In practice, however, the Dutch did not take any substantial measures against the consumption of opium in their colonies. Until well into the 20 th century, the profits from opium were too substantial to permit any form of general prohibition. The Second World War and the subsequent independence of Indonesia marked the end of the Dutch opium trade in Asia. 4

In addition to the financial interests of the opium trade, the production of coca leaves and cocaine also played a crucial role in contributing to the Dutch treasury. Around 1860, efforts to extract cocaine from coca leaves were successful, resulting in a fast rise in the popularity of this drug. Initially, the coca leaves came from Peru and Bolivia. The Dutch saw a new market, and in 1878 coca plants were transported from South America to the Dutch Indies, where beginning in 1886, important and continuously expanding plantations were established. In the beginning, coca from Java, the island with the largest number of plantations, could not compete with the leaves imported from other countries. However, the quality of the coca harvest improved steadily and considerable energy was devoted to the careful packaging and transportation.

The production of coca leaves increased sharply during the first decades of the 20th century. While in 1907 only 200 tons of leaves were produced in the Indies, in 1914 this had increased to almost 1,400 tons. During the First World War, the transportation to Europe became seriously impaired and export declined sharply (to less than one-and-a-half ton in 1916). After the war, however, the export of coca leaves quickly recovered and peaked in 1920 with more than 1,700 ton. At that time, the Netherlands had been the largest cocaine producer of the world for nearly ten years. By far the largest portion of the coca leaves was trans- 
ported to the Netherlands. The largest customer was the Dutch Cocaine Factory in Amsterdam, established in 1900. The Amsterdam-based firm Cheiron as well as Brocades and Stheeman in the eastern part of the Netherlands also produced cocaine.

Although the Dutch maintained that its cocaine was produced exclusively for medical purposes, it is plausible to assume that an important portion was used purely for recreative purposes. In 1922, it was estimated that the world need for cocaine for medicinal purposes was some 12,000 kilos. The production of coca leaves in the Indies $(1,283,503$ kilos) alone would have been more than sufficient to satisfy this demand; similarly, the export of coca leaves from Peru and Bolivia together would also have satisfied the world demand (Gavit 1925). It should be noted, however, that the cocaine for recreational purposes, to a large extent, was brought into circulation through medical channels at that time, which made the medical need appear much more substantial than it really was.

The Netherlands was by no means the only country in the world which had important economic interests in the production and trade of drugs. Germany produced cocaine and codeine and England produced morphine. Persia (now Iran) had interests in the cultivation of the poppy and Portugal produced opium in Macao, while France made money on opium in Indochina. Yet, the Netherlands was viewed by the Americans as one of the worst "evil-doers", in particular because of its coca production. For example, Java and the Netherlands were mentioned in one breath with Peru and Bolivia (Musto 1987). As recently as 1931 and 1940, the League of Nations referred to the Netherlands as one of the most important producing and exporting countries (Chatterjee 1981). Yet, Dutch representatives attending international opium conferences at the beginning of the 20th century were not very cooperative. The reluctance of the Dutch to cooperate with international efforts to control drugs was not surprising in view of the potential loss of substantial profits for the Dutch treasury.

\section{The International Opium Conferences and the Opium Act}

In 1909 , at the initiative of the United States, a commission convened in Shanghai to discuss the international opium trade and opium consumption in the colonies. With the exception of the United States, the participating countries were not at that time concerned with drug use in their own country. This lack of concern with domestic drug abuse was also true for the Netherlands. The chair of the commission, Bishop Brent from the United States, had hoped to assemble a conference (rather than a 
commission) - a diplomatic meeting which would result in official measures by the represented governments. At the request of Great Britain and the Netherlands, however, the Shanghai meeting remained limited to a commission: "a fact-finding body which could make only recommendations and not commitments" (Musto 1987:35). The opium commission formulated nine recommendations; the main impact of these recommendations was that they provided the foundation for further negotiations.

Again based on American initiative, an international opium conference met in The Hague in 1911 to translate the Shanghai recommendations into actual legislation. Organizing the first international opium conference was not a simple task. The United States felt that international regulations took much longer than anticipated. Under the leadership of Dr. Hamilton Wright, a physician with strong political interests, the United States began to express concern that a conspiracy existed against the American "crusade" against drug use. To add insult to injury, Germany, England and the Netherlands gave the impression not to have any real short-term need for such a conference. Wright decided to take the offensive against this apparent inertia: "(he) sought out the Dutch minister to the United States, then vacationing in Maine, and threatened that if the Netherlands continued to procrastinate, the United States might convene the conference in Washington" (Musto 1987:49). Ultimately, the Netherlands organized the first international opium conference, resulting in the Hague Opium Convention of 1912. The largest portion of this convention consisted of guidelines regarding the regulation of the production and trade of opiates and coca(ine). Article 9, which required participating countries to enact legislation to limit the production and sale of drugs to medicinal purposes only, is most crucial for the present discussion. This article provides the foundation for the 1919 Dutch Opium Act. ${ }^{5}$

It took several years, however, before ratification of the 1912 Opium Convention. Article 31 of the convention required the organization of another conference, if the agreement had not been ratified by all participating countries by December 31, 1912. It became apparent that individual governments, including the Netherlands, were not in any hurry to ratify the convention; consequently, a second and even a third conference, respectively in 1913 and 1914 , were necessary to urge the participants to take appropriate action. At the 1913 and 1914 meetings, the Netherlands argued in favor of expedient ratification and swift adjustment of national legislation; yet, the Dutch government dragged its feet the longest. It was not until February 1915 that the agreement was finally ratified. 
Vested economic interests in the production and trade of drugs may explain the Dutch reluctance to endorse strong international drug control. Clearly, the Netherlands attempted to protect these interests at the conferences (Wissler 1930) and did so successfully, at least temporarily. During the international meetings, the Dutch position was made very clear and explicit. At the first opium conference, the Netherlands argued in favor of a government monopoly on opium. The opium trade would need to be left solely to the governments; and smuggling needed to be combatted forcefully. The Dutch delegates characterized the smugglers as "our greatest enemies" (Chatterjee 1981). Indeed, the Netherlands maintained a government monopoly on opium in the Dutch Indies until the invasion of the Japanese army in 1942. In addition, the Netherlands also disagreed with attempts to regulate the cocaine trade. Ultimately, the international treaties did not harm the Dutch interests in this white powder for a long time. Incidentally, the Netherlands also objected to the inclusion of marihuana in the convention.

Chatterjee (1981) characterizes the Dutch position during this international discussion until the Second World War as "pseudo-obligation...neither self-induced nor genuine". The Netherlands, however, overestimated the possibility of guaranteeing its own interests. The Netherlands hoped to reserve the right to withdraw from the Opium Convention in case of conflicting interests, or not to ratify any international agreement which would threaten economic interests too much.

At the domestic front, the feasibility of employing legal measures and international cooperation to control illegal drug trade started to raise questions in the Netherlands as early as the 1920s. The majority opinion in the Netherlands was that the "war on drugs" (as we call it now) could not be won. Several Dutch sources from that period suggest that the illegal drug trade would be difficult to control due to the importance of the financial and economic interests involved in the highly priced, easily concealed drugs: "The simplicity of the restriction notion is, however, only superficial: one will encounter virtually unsurmountable difficulties in any attempt to implement this notion into practice" (Tan Tong Joe 1929:13-14; author's translation). The notion that it was possible to eliminate international illegal drug smuggling was referred to as the "American position" - a position which is "(virtually) unenforceable" (Tan Tong Joe 1929:13-14). 


\section{The reluctant and selective enforcement of the Opium Act}

Other countries criticized the Netherlands for their lenient drug control measures. This may be illustrated in the following example, which caused an international stir. In 1928, when the Netherlands had not yet introduced a certification system to regulate international trade, the Chemical Plant Naarden was able to buy and sell about half of the world production of heroin. Meanwhile, other countries had already passed legislation to prohibit this, but in the Netherlands where this was still completely legal, the Chemische Fabriek Naarden obtained a government permit to produce and sell drugs. The Opium Commission of the League of Nations was very critical of this action.

After the enactment of the 1919 Opium Act, transportation of drugs and drug trading had become illegal. Although it was still possible for businesses to participate in drug trade through a system of permits, a substantial (extensive) smuggling trade could not be prevented. ${ }^{6}$ Soon after the enactment of the Opium Act large quantities of illegal drugs were confiscated. For example, in the harbor city of Rotterdam in 1920, a shipment of morphine was found with an estimated value of 50,000 German Marks. Two years later, in a town near the German border, 700 flasks of morphine, which were intended to be distributed to different regions in the country, were confiscated. In 1925, there was an attempt to use safes to smuggle 50,000 Guilders worth of cocaine and morphine from the Belgian city of Antwerp to Rotterdam. In England, a 29-year-old Dutch citizen was convicted of the illegal possession of cocaine. According to the police, this Dutchman had been living in London for a few years, but he travelled repeatedly to the Netherlands and France to buy cocaine (Parssinen 1983). Interestingly, the Dutch were convinced that international organized crime was responsible for the large-scale smuggling. The introduction of the system of certification in 1928 was not able to suppress drug smuggling either. Ever more creative means were invented to transport drugs across national borders. It was close to the Belgian border that the first suitcases with false bottoms were discovered in 1930 .

The fight against drugs became increasingly professionalized in the 1930 s, at both national and international levels. During the 1930s, there were regular international meetings of police authorities to discuss how to combat drug smuggling more effectively. The Rotterdam police established a special Narcotics Division. At that time, the United States played an important role in the internationalization of the fight against drugs:

"The Americans have built an organization in Europe to assist the European police in all possible manners and, of course, to also prevent 
the transportation of drugs from Europe to the United States" (Nieuwe Rotterdamsche Courant 1939; author's translation).

Not surprisingly, the Opium Act virtually did nothing to stop drug smuggling. The popular press repeatedly complained about the lack of effective measures. For example, in 1921, the Pharmaceutical Weekly predicted that "...the Netherlands will shortly become the center of a clandestine opium and cocaine trade".

The maximum sentence for violation of the Opium Act was increased from three months imprisonment and a 1,000 guilder fine in 1919 to one year imprisonment, with the same fine, in 1928. In practice, it was the smuggler who received the most severe sentence. For example, those involved in the smuggling of morphine and cocaine in safes received the maximum sentence. On the other hand, pharmacists who violated the law by selling opiates or cocaine without prescription received lighter sentences. To illustrate, the prosecutor asked for three months imprisonment of a pharmacist who had provided drugs to "morphinists" (Pharmaceutisch Weekblad 1938:1209). Addicts were typically not convicted under the Opium Act. There was one group of users, however, who was more likely to be prosecuted: the Chinese opium smokers. The first Chinese group of immigrants arrived in 1911 in Rotterdam to break the seamen's strike. After a few years, this group had developed its own "Chinatown" both in Rotterdam and Amsterdam. Opium smoking was very popular in the Chinese community; an estimated $75 \%$ of the Chinese smoked opium. The arrival of the Chinese introduced the use of opium in the Netherlands. After 1919 it was this particular group of users who was singled out for prosecution, because their method of consumption was foreign to European norms, not serving any medicinal purpose, and being used exclusively for recreational purposes. In addition, the Chinese were an easily distinguishable and isolated group for the police. The Chinese smoked their opium in opium dens, which were easy to locate by law enforcement officials. Generally speaking, rather mild sentences were given to Chinese who were prosecuted under the Opium Act. Possession of opium for personal use was permitted; however, if one was in possession of more than two grams, prosecution resulted. Fines varied from between 25 to 50 Guilders.

This does not mean that it was only the Chinese who used drugs. Police reports from the 1920 s suggest a widespread use of cocaine by seamen congregating in certain neighborhoods attracted by prostitution and bars. Most of these users, however, obtained the drugs through a physician's prescription. A 1937 study indicates that physicians prescribed large quantities of cocaine, morphine, and the opiate Dilaudid for their 
patients. Very little heroin was used. The Opium Act could not be used to prosecute these users, because physicians were allowed to prescribe drugs.

\section{Comparisons of drug policy in the Netherlands, Great Britain and the United States before the Second World War}

I have already discussed the notion that vested economic interests were an important explanation for the apparent reluctance of the Dutch to fully endorse international agreements concerning drugs. It seems that the noted lack of a stringent enforcement at the domestic level, however, requires an explanation involving additional factors. In this context, it is useful to draw upon the work done by Parssinen (1983) who compares the American repressive approach of the 1920 s with the more medically oriented approach of Great Britain. He explains the differences in approach by the presence of problematic recreational user groups in the United States while comparable problematic drug-using groups were virtually absent in England. In the United States, a large Chinese community existed from which recreational drug use gradually spread to other groups. Parssinen argues that the Chinese community in England was much smaller and more isolated than in the United States. When we include the Netherlands in this comparison, an interesting commonality with the English development may be noted. As in England, the Netherlands did not have a large group of recreational drug users who were viewed as causing social unrest. Although the Netherlands had the largest Chinese community in Europe, in comparison with the United States, this community was relatively small and isolated from other groups. It is noteworthy, however, that it was mainly Chinese users who were prosecuted in the Netherlands, in spite of a relatively permissive attitude. Yet, it may be argued that in the Netherlands, as in England, it was the absence of a large group of recreational drug users and the small size of the Chinese community which accounts for the absence of a repressive approach.

Another cause for the differences in policy between the United States, Great Britain and the Netherlands may be the differential impact of the medical profession on policy. According to Stein (1985), physicians in the United States had little influence at the federal level, where drug policy was formulated. In the United States, medical interest groups were active at state level, not at federal level. The medical profession in Great Britain was much more influential in setting public health policy than in the United States. This is reflected in the composition of the Roleston 
Committee which was established in 1924 to answer the question of whether doctors should be allowed to prescribe opiates and cocaine to addicts. The Committee consisted mainly of physicians, who were able to implement a medical approach: "Above all, they were medical men who were defending the professional prerogative of the physician to exercise control over the drugs he administered" (Parssinen 1983:220).

In practice the Dutch policy on drugs was very similar to the British policy during the period of 1920 through 1955. However, there was no Roleston Report, so there has never been any mention of the "Dutch medical model". Enforcing the Opium Act was a task for the Justice and Health Departments. Police and the Justice Department focused on the prosecution of illicit trafficking and smuggling, while physicians were concerned with the addicts and were authorized to prescribe drugs to addicts. This separation of tasks and authorities between health and justice officials, due partly to regular interdepartmental exchanges of views, was well balanced. The moment the police and the Department of Justice concerned themselves with prescribing physicians and addicts, the Health Department would intervene. It did not allow the prerogatives of the medical profession to be violated. One such incident occurred for instance in 1937 when the police initiated an investigation of the use of drugs and the degree to which doctors prescribed drugs to patients. The police sent alarming reports to the Justice Department, allegedly indicating that doctors and pharmacists prescribed drugs on a large scale to supply addicts. The Health Department reacted furiously to the reports provided by police authorities. It charged the police with unauthorized interference in public health matters. Police officials were said to be unable to judge whether drugs were used for recreational purposes.

It was made abundantly clear that there were no violations of the Opium Act and the police were not authorized to investigate doctors. This was a task for the Health Department.

\section{Developments after the Second World War}

Shortly after the Second World War, Amsterdam established its own two-member Narcotics Division. The establishment of the Amsterdam Narcotics Division was triggered by increased smuggling by Germans from the supplies of drugs from the capitulated German Army. (As we already have seen, Rotterdam established its own Narcotics Division before the Second World War.) In the first few years after the war, drug use did not receive much attention. Drug enforcement officials apparently observed very little recreational drug use. There were few ar- 
rests and the amounts of confiscated cocaine and morphine were negligible. Opium smoking by local Chinese was generally tolerated. However, Chinese seamen who smuggled kilos of opium were prosecuted.

Before the war, there was virtually no use of marihuana in the Netherlands. Only artists and writers occasionally experimented with the smoking of hashish and marihuana. After the war, the use of these drugs was mostly associated with “...swing musicians, black and white musicians, who try to identify with this music. Trade is concentrated in the cosmopolitical downtown areas of Amsterdam and Rotterdam, the only places where the few black bands that exist in our country can find employment. This trade often involves swindling: all too frequently the socalled reefers are, for instance, opium cigarettes" (Van Wolferen 1949:323; author's translation).

After the Second World War, the trade in marihuana cigarettes increased. However, the police could not do anything about it, since the possession and sale of this drug was not yet illegal. In 1953, possession of marihuana became illegal under the Opium Act and in 1955 the first arrests took place among marihuana smugglers and marihuana users. Attention was focused primarily on American soldiers of the Allied Forces in West Germany, who would come to the Netherlands on "pay day". Marihuana was sold to the American soldiers by Dutch people, who obtained the drug from sailors. As far back as 1955 the Amsterdam Narcotics Division cooperated with the American Office of Special Investigation at Soesterberg Airbase. In that year, three American soldiers were arrested for possession of 60 marihuana cigarettes, a considerable amount for that time period. A painter was convicted to a three-month suspended prison sentence because of possession of two marihuana cigarettes. According to the annual reports of the Amsterdam Narcotics Division, the trade in "Indian hemp" was mostly in the hands of persons who came from the colony of Surinam.

The 1960s signaled a turn in drug use and drug policy in the Netherlands. Marihuana, and to a lesser degree, amphetamines were more visible and its use was no longer restricted to artists, students, and so on. During this time, the police would hunt intensively for a few grams of marihuana or hashish. The penalties were quite severe. Users with a minimum amount of marihuana in their possession were often sent to prison for a few months. However, this repressive approach could not prevent a fast increase in the use of marihuana, particularly with the rise of the 1960s' youth culture (i.e., Provos or beatniks and hippies).

LSD was first imported from England in 1965 in relatively large quantities and its use spread quickly. As Cohen (1975) points out, this fast 
dissemination of LSD could only take place because of the presence of a large supply of the drug and the willingness of large groups of people to accept the drug. In 1966, there was a wave of sensational publicity in the newspapers which fueled the fear of LSD. The Telegraaf, a popular newspaper, argued: "A small lump of sugar quickly takes the user to a fantasy world but LSD causes insanity". Not even two weeks later the Opium Act was expanded to include LSD, together with another 18 psychedelic drugs. 7

During the 1960s, use of opium in the youth culture was also expanding. Up to that time, the Chinese opium dens were more or less tolerated. However, as soon as Dutch youth began to buy their drugs at the opium dens, a more repressive policy was implemented against both the smoking and injection of opium. This situation continued until the arrival of larger amounts of heroin in 1972.

\section{Decriminalization of marihuana}

One of the most noteworthy aspects of Dutch drug policy in the 1970 s was the de facto decriminalization of the use of marihuana and the smallscale dealing in youth centers and so-called coffee shops. This is a striking development in view of the fact that only ten years earlier the prosecution of users and dealers of this most frequently used drug was still a high priority for the criminal justice system. Furthermore, smoking of marihuana or hashish was by no means a socially accepted custom in the Netherlands of the 1960s. How, then, may we explain the development of the internationally "deviant" Dutch drug policy of the 1970s? A comparison with the United States may shed some light on this question.

A comparison between the United States and the Netherlands with regard to marihuana shows an important difference. Marihuana in the United States was associated with a "marihuana ideology"; first as a "killer weed", causing violence among its predominantly Mexican-American users, and later as a middle-class youth "drop-out drug" (see Himmelstein 1983). The Netherlands, on the other hand, lacked a specific ideology associated with marihuana. Before the Second World War, there was only a very sporadic use of marihuana. After the war, although there was some use in circles of jazz musicians and American soldiers, the use was so limited that an ideology never developed. The already noted repressive response to all drugs in the early 1960 s reflected concern with law-breaking per se, rather than a strongly held belief system about the evils associated with marihuana use.

The Netherlands also lacked a moral entrepreneur, like the Federal 
Bureau of Narcotics in the US, interested in criminalizing this drug. In the Netherlands marihuana use was not linked to a particular ethnic group, like the Mexican-Americans in the US. The "killer weed" ideology never existed in the Netherlands; the use by the youth culture in the 1960 s was the first confrontation of society with marihuana. Marihuana did become a symbol of the counterculture and played, therefore, a role in this broader social and political movement. When confronted with the need to respond to increasing marihuana use, Dutch policy makers could thus develop new policy unencumbered by the weight of an already existing, emotionally charged ideology.

This does not address the question of why the Dutch "ideological answer" was not formulated in the obvious prohibitionist model, consistent with international norms. A possible speculative answer to this question may be found when we consider the political, cultural, and social changes which took place in the Netherlands in the 1960s. From about 1917 till the 1960s, pluralistic Holland may be characterized as a "pillarized" society. The pillarized society consisted of groups with their own ideology, philosophy of life, or religion. There was little contact between the firmly organized different pillars. Nonetheless, the Netherlands had a very stable democratic system. An important condition for this stability was that the elites of the different pillars made compromises at the political level. These compromises developed on the basis of the "consociational democracy" (Lijphart 1968). In this manner, conflicts within the pluriform and divided society were made manageable through the compromises reached by the elites, which resulted in political stability (cf. Van Schendelen 1984).

However, in the 1960 s, this system more or less collapsed. Decreased religious involvement, expansion of the means of communication and increased prosperity all contributed to the process of de-pillarization. People no longer felt committed to their philosophical or ideological pillar and came into contact with other philosophies of life. This de-pillarization was also noticeable at the political level, which meant the demise of what may be called the "pacification democracy". These changes provided groups which did not belong to one of the pillars with a chance to play a role in the political and social world. At the political level, this was reflected in the emergence of new, relatively successful political parties, which broke through the relatively homogeneous political culture. Outside the realm of politics, new groups received the opportunity to influence social life. This was also true for the youth culture which, in this time of social change, was not relegated to a marginal social position. Unlike many other countries, in the Netherlands drugs and countercul- 
tures associated with drugs were thus not marginalized and combatted with criminal justice measures. These changes meant that the Netherlands could develop an alternative drug policy - within the parameters of international agreements. The Single Convention of 1961 did not permit legalizing cannabis. The only possibility within the margins set by the Convention was the de facto decriminalization of cannabis.

\section{The Baan Commission}

With the increasing recreational use of drugs in the 1960s, the need for alternative policies was recognized. In 1968 a committee (the Baan Commission) was appointed with the mandate to re-evaluate governmental drug policy. The composition and recommendations of the Baan Commission will be discussed in the next chapter; suffice it to say here that the report of this commission formalized the philosophical and legal foundation of current Dutch drug policy. The report made a distinction between soft drugs (i.e., marihuana and hashish) and hard drugs. Generally speaking, soft drugs were considered relatively harmless; users and small dealers were essentially to be left alone. Addiction to hard drugs was viewed primarily as a medical problem; it was decided that hard drugs should remain illegal. The report supported a "two-track" policy: a medical approach to addicts and a criminal justice-oriented (repressive) approach to large-scale dealers of hard drugs.

One of the most important foundations of Dutch hard drug policy, as formulated by the Baan Commission, is that the emphasis be on the medical-social care of users and prevention. We may list three different reasons for this.

1. Dutch society has a well-established tradition of social legislation and good medical care. Building a system of social welfare legislation has been important since the early period of pillarization. It was believed that social legislation and good medical care for the lower classes would alleviate class conflict and promote unity within the pillar. The system of pacification democracy, in a sense, encouraged the implementation of government measures to promote social well being. It is not surprising that, in a country where the well being of the population in the form of social legislation and good medical care is an important government task, medical-social care plays an important role in drug policy. Increased prosperity after the Second World War brought in abundant tax income which enabled the Dutch government to implement an ever improving system of social legislation and medical care for its citizens. 
2. The hard drug policy formulated by the Baan Commission did not represent a radical change, rather an adjustment and refinement of an already existing approach. Indeed, the emphasis on medical and social care was a continuation of the long established balance between a repressive and a medical approach. As the preceding brief overview has documented, the Netherlands has followed a two-pronged approach (repressive and medical) since the 1920s.

3. A possible third reason for the medical approach to hard drug use may be the absence of a heroin problem in the Netherlands at the time of publication of the Baan report. In the United States and Great Britain, the medical approach was abandoned during periods when recreational use of heroin became a main concern. Heroin was not found on a larger scale in the Netherlands until the summer of 1972, six months after the Baan report was published.

\section{Conclusion}

Dutch drug policies with respect to the supply side of the drug market reflect, to a certain extent, the international repressive norm. There are, however, important national differences with regard to policies related to the demand side. In this brief overview, I have attempted to demonstrate that the "alternative" Dutch drug policy with regard to the demand side is the product, to a significant degree, of national political, social and cultural circumstances. Our historical analysis clearly suggests that the formulation of drug policy is more than a rational weighing of different alternatives and developing political choices. Government policies are the product of national historical developments and circumstances. Caution must be used, therefore, in adopting the position that the Dutch policy should be used as an "example" for other countries. This will be discussed in more depth in the concluding chapter of this book.

\section{References}

Berridge, V. and Edwards, G.: Opium and the People: Opiate Use in Nineteenth-Century England. New Haven, London: Yale University Press, 1981

Broers, J.: Alcoholisme, Morphinisme, Chloralisme. Leiden: Uitgeverij Slotboom, 1886

Chatterjee, S.K.: Legal Aspects of International Drug Control. The Hague: Martinus Nijhoff, 1981

Cohen, H.: Drugs, Druggebruikers en Drug-scene. Alphen aan den Rijn: Samson, 1975

Courtwright, D.T.: Dark Paradise: Opiate Addiction in America before 1940. Cambridge MA / London: Harvard University Press, 1982

Diehl, F.W.: The Opium Tax Farm on Java, 1813-1914. Paper, 1993

Erlenmeyer, A.: Die Morphiumsucht und ihre Behandlung. Berlin, 1887 
Gavit, J.P.: Opium. London: Routledge \& Sons, 1925

Gunkelman, M.: Vom Wunderheilmittel zum socialen Gift. Der Wandel des Kokaingebrauchs und seiner sozialen Bewertung in Deutschland bis 1930. Diplomarbeit. Frankfurt/M, 1984

Himmelstein, J.L.: From killer weed to drop-out drug: the changing ideology of marihuana. Contemporary Crises 7:13-38, 1983

Kaplan, C.D.: The uneasy consensus: prohibitionist and experimentalist expectancies behind the international narcotic control system. Tijdschrift voor Criminologie 26:98-109, 1984

Kreutel, M.: Die Opiumsucht. Stuttgart: Deutsche Apotheker Verlag, 1988

Lijphart, A.: The Politics of Accommodation: Pluralism and Democracy in the Netherlands. Berkeley: University of California Press, 1968

Musto, D.F.: The American Disease, Origins of Narcotic Control. New York: Oxford University Press, 1987

Nieuwe Rotterdamsche Courant, 22 February 1939

Osiander, J.F.: Volksgeneeskunde, of Eenvoudige Middelen en Raadgevingen tegen de Kwalen en Krankheden der Menschen. Leeuwarden, 1854

Pharmaceutisch Weekblad, p 1209, 1938

Parssinen, T.M.: Secret Passions, Secret Remedies: Narcotic Drugs in British Society 18201930. Philadelphia: Manchester University Press, 1983

Rush, J.R.: Opium Farms in Nineteenth Century Java: Institutional Continuity and Change in a Colonial Society, 1860-1910. Dissertation. Yale University, 1977

Scheerer, S.: Die Genese der Betäubungsmittelgesetze in der Bundesrepublik Deutschland und in den Niederlanden. Göttingen: Verlag Otto Schwarz, 1981

Stein, S.D.: International Diplomacy, State Administrators and Narcotics Control. Hampshire, Brookfield: Gower Publishing Company, 1985

Tan Tong Joe: Het Internationale Opiumprobleem. Dissertation. The Hague, 1929

Van Schendelen, M.C.P.M. (Ed.): Consociationalism, pillarization and conflict-management in the low countries. Acta Politica xix, January 1984

Vanvugt, E.: Wettig Opium. Haarlem: In de Knipscheer, 1985

Van Wolferen, M.D.: Marihuana. Tijdschrift voor Strafrecht 308-323, 1949

Verdoorn, J.A.: Het Gezondheidswezen te Amsterdam in de 19e Eeuw. Nijmegen: Sun, 1981

Wissler, A.: Zur Geschichte der Opiumfrage. Dissertation. Jena, 1930

\section{Endnotes}

1. See, for example, Kaplan (1984).

2. A. Erlenmeyer (1887) counted between 1864 and 1886, 260 German, French or English language publications on this topic.

3. See, for example, for the United States: Musto (1987) and Courtwright (1982); for England: Berridge and Edwards (1981) and Parssinen (1983); for Germany: Scheerer (1981), Gunkelman (1984) and Kreutel (1988).

4. For more information on the use and trade of opium in the Dutch Indies see Vanvugt (1985), Diehl (1993) and Rush (1977).

5. The Dutch Opium Act was implemented in 1919. The Opium Act included opium and its derivates as well as cocaine. The Opium Act prohibited the preparation, sale, processing, delivery, import and export, and possession of drugs with intent to deliver. The Opium Act was revised in 1928, because of an international agreement signed in 1925 , which in turn was a supplement to the 1912 agreement. The 1928 revision also included marihuana and cocaine derivates. In addition, the punishment was increased from a maximum of three months in 1919 to one year in 1928. 
6. After the enactment of the Opium Act of 1919 several businesses obtained permits to produce and/or deal in drugs. The system of certification introduced in the Netherlands in 1928 was designed to regulate the importation and exportation of narcotics. For example, whenever a business wanted to export heroin, it had to produce a certificate from the receiving country to obtain a permit to export.

7. This publicity wave and the subsequent prohibition of LSD were probably related to the threat of the Provo's to interrupt the approaching wedding of the then Princess Beatrix and the German Prince Claus by poisoning the Amsterdam drinking water with LSD and by giving LSD-tainted lumps of sugar to the horses. 


\section{INITIAL CONSTRUCTION AND DEVELOPMENT OF THE OFFICIAL DUTCH DRUG POLICY}

Ed. Leuw

\section{Introduction}

Modern drug use appeared in Dutch society at the end of the 1960 s. During these early years, the recreational use of illegal substances by sometimes non-conformistic, but definitely non-marginal youth gained some prominence, although perhaps more in public awareness than in numbers. The nature of this drug use, a rather uninhibited and even somewhat ostentatious use of cannabis, implied that value conflicts rather than objective problems were at the core of the initial phenomenon. At the end of this period drug use had spread throughout the population to a certain extent. At the same time, as a consequence of the introduction of opiates and the emergence of some related social and public health problems, the drug issue now had become more than being just a "simple" value conflict.

During several years a drug policy debate took place among politicians, administrators and professionals on the principles of the social control of this problematic phenomenon. At the end of this initial phase of modern drug taking in the Netherlands the debate had come to a temporary conclusion regarding moral character and harmfulness. Ahead of popular opinion, professionals and political administrators increasingly adopted a morally dispassionate and, in terms of drug ideologies, more liberal and less prohibitionistic course.

The end of the process of establishing a "pragmatic and normalizing" drug policy was reached in 1976, when the Revised Opium Act was enacted in the Dutch parliament. This event marked the end of an era characterized by an ideology of prohibition and moral rejection of any kind of (illegal) psychotropic drug use. The social debate on the significance of drug use had evolved towards more pluralism and diversification.

The new drug legislation of 1976 laid the cornerstone of a comprehensive drug policy program. It involves education, prevention, general "youth policy" and measures specifically targeted at drug users, such as social assistance and psycho-medical therapy. 
In a formal legal sense the Revised Opiate Act of 1976 may be understood as the penal law part of this more general drug policy program. The program as a whole reflects the central elements of Dutch drug policy: tolerance for non-conformistic lifestyles, risk reduction with regard to the harmful health and social consequences of dangerous ways of drug taking and, finally, penal law measures directed against the illegal economy of (hard) drugs. Reconciling these partly conflicting elements with one another has been (and still is) the really hard part of developing drug policy.

In retrospect, this multi-faceted framework of social control has firmly established the basic principles as well as the common practices of social and penal law drug policy in the Netherlands (Van de Wijngaart 1991). It has served this role until the present day, with surprisingly little emotions or public dissent in Dutch society. Since these early days, the national drug policy has become more a matter of technical and administrative concern than a matter of principles. In this Chapter, the social political process which has resulted in Dutch "pragmatic and non-moralistic" drug policy will be described and to some extent, explained.

\section{Social and cultural backgrounds of the initial problem definition}

Although opiates and cocaine have, to a limited extent, been present in Dutch society during the last 100 years, the issue of drug taking as a focal and public social concern hardly existed before approximately 1965 (De Kort 1989). The public and political awareness of addiction and substance use as a social problem was restricted to alcohol. Similar to the rest of the Western world, this traditional substance of pleasure and problems had a long history as a significant social problem. The social problem concept implies the presence of medical, mental health, moral, educational and criminal policy concerns. Alcohol used to be the one and only widely available substance for which possible misuse transcended purely individual problems, and as such alcohol qualified as a bona fide social problem. Drug taking and addiction only existed as rare phenomena of personal misfortune which could be dealt with by the medical profession and by an appeal to self-evident morality. For such problems, social control issues are either non-existent or they are taken for granted. In sum, there used to be no more need for social policy debate on drug taking than on suicide, heart diseases or insanity.

Starting from about 1965 things changed rapidly and radically. Drug taking as a social problem first came to the public consciousness in the much broader cultural context of the diversification of lifestyles and 
value systems. In this era, a broad variety of moral constraints and normative expectations was successfully challenged. This cultural process involved important issues of lifestyle, sexual behavior and the conventions of public appearance. It also involved a certain diminishing of traditional power differentials between groups in society, such as between generations, females and males, or the social-economic (and the political) status groups.

In this process of rapid re-orientation of social values the so-called counter-cultural "alternative" youth culture played a major role. Its growing social power manifested itself primarily in the traditionally liberal city of Amsterdam. During the last years of the 1960s the "Provo's", a loosely organized group of young cultural rebels, had gained some prominence in the city. They were highly visible and generally admired by otherwise more conformistic peers. The Provo-movement playfully provoked the Amsterdam city administration and police in various inventive ways. Stretching the borders of social and personal liberty was the movement's explicit aim. Challenging the public order regulations and some penal law prohibitions was its strategy. Weekly "happenings" downtown delighted the young, partying crowds, while making the authorities quite nervous. Publicly smoking pot was part of the provocation game. The movement's success in influencing the social and cultural order was reflected in the dismissal of both the mayor and the police commissioner of Amsterdam following the peaceful but effective turmoil the Provo movement created. Because of their overreactions to the provocations of the Provo's, the positions of both authorities were undermined.

It may be significant for further developments of drug policy (and other legislation in the sphere of "victimless crimes") that this movement was partly absorbed into the conventional political structure of the city of Amsterdam. Part of the Provo movement was transformed to a political "party" at the city level. It won some seats in the city council. Occasionally blowing pot during its meetings was one way to make it clear that simple prohibition would no longer do as the mainstay of drug policy. A few years later one of the leaders of the Provo movement was appointed as alderman in Amsterdam.

Perhaps because of this close identification with counter-cultural lifestyles and values, the initial concept of drug-taking as a social problem in the Netherlands has been fundamentally ambivalent. It incorporated appreciations of personal freedom and tolerance as well as depreciations of deviance, pathology and immorality. The original phenomenon of "drug-taking" (which in practice meant the use of cannabis) was one of the cases that passed the test of the often claimed relative permissiveness 
and tolerance of Dutch society, comparable to the normative acceptance of other moral value innovations in this same period: legalized abortion and pornography, and the more uninhibited manifestations of prostitution, homosexuality and hedonistic sexuality in general.

At the end of the decade of the 1960s the phenomenon of (illegal) drug use (LSD and amphetamines were not yet outlawed) had spread sufficiently to generate widespread confusion, anxiety and some moral outrage in general Dutch society. The public dispute mainly centered around the highly symbolically loaded use of psychedelics (cannabis and LSD) by a young non-conformistic, but non-marginal avant-garde. At the onset of this development the drug-takers could broadly be defined as young or even not-so-young bohemians (Cohen 1975). Later, with the flowerpower revolution well on its way, those groups were referred to as hippies.

Social reactions to the drugs' symbolism intensified when it became inescapably clear to parents, educators and legislators alike, that the hippie lifestyle was appealing to broad segments of the "normal" young generation, perhaps even to their own children. This phenomenon was met with contradictory and ambivalent reactions. By some it was welcomed as a humanistic liberation from worn-out moral and social constraints. The hash-blowing "hippies" had many supporters among liberal new elite groups, such as the young university graduates who were taking positions in the rapidly expanding world of (mental) health, welfare and social policy institutions. To many of this (increasingly influential) group of policy makers the hippies appeared as the bearers of the key to a better world of love, understanding and carefree hedonism. In this context drugtaking (smoking pot) appeared as a sacred ritual which should be shielded from narrow-minded interference by conventional ("square") society.

On the other hand, several other groups in Dutch society of around 1970 were indignant about the hippie lifestyle and (psychedelic) drug-taking. Typically they were the older moral conservatives who were at a clear disadvantage as they had to ride against the high tide of fashionable tolerance and pluriformity. They appeared as rather unglamorous representatives of a silent moral majority, the so-called "concerned citizens" groups of medical doctors, parents and educators, and some law enforcement officials. The one and only cabinet minister (R.J.H. Kruisinga, a Christian Democratic state secretary for public health, a physician by profession) who actively sided with this moral opposition and rallied on the theme of radical prohibition, was cheerfully mocked by the flourishing underground press and by one of the major public radio networks. 
Apart from the rapidly growing numbers of cannabis experimenters and users around 1970, serious drug problems were still quite rare. Social drop-outs, (mental) health troubles, and drug-related criminality were reported in the context of some LSD, opium and amphetamine use. But although they were seen as a disturbing prospect by many social policy officials, those cases were too small in numbers (no more than several hundreds) to be a genuine cause for concern.

As we will see, the first professional study and advisory groups, which were officially appointed around 1970, have been quite influential in the formulation and execution of what in recent years has come to be known as the "Dutch model" of drug policy. It is of utmost importance that these working groups were established in an era and in a society where drug use had come to the public consciousness against the backdrop of a relatively mild dispute of lifestyles and value systems, and not against a background of criminality, pathology and deeply rooted social conflict. The latter elements certainly did enter the Dutch drug problems field in later years; however, by then the tradition of non-moralistic accommodation and pragmatic risk management in drug policy was already firmly established.

\section{The initial formulation of drug policies and the construction of the revised opium law of 1976}

In the years 1969 and 1970 two expert committees, one private and one state committee were appointed, both charged with constructing a model for the social policy towards the use of illegal drugs. Essentially, their mission was to construct a definition and a normative orientation towards a hitherto non-existing social phenomenon. Culturally and historically many options were still available. Because this was a relatively new problem in Dutch society, the course of social policy had not yet been charted on the track of prohibition and moral rejection.

Both committees finished their task after about two years. The reports they produced were concise, each one of them can easily be read in less than two hours. They have, each in their own way, exerted much influence on the processes of formal law construction and the execution of social drug policy until the present day. The line of reasoning and the conclusions that were reached in those reports were not unlike the results of similar working groups in the US, Canada, and the UK (Advisory

Committee on Drug Dependence 1968; National Commission on Marihuana and Drug Abuse 1973; Commission of Inquiry into the Non-Medi- 
cal Use of Drugs 1972). The real difference is that the Dutch reports have been much more influential in shaping actual policy.

In 1969 the state-sponsored Institution for Mental Health appointed the working group that produced a report "Options in Drug Policy" ("Ruimte in het Drugsbeleid"). The committee was chaired by Loek Hulsman, a penal law professor reputed for his abolitionist's views. It consisted of 14 persons, who were representatives of scientific disciplines, high-ranking law enforcement officials, representatives of the ministries of justice and public health, and directors of mental health and welfare institutions. It is important that at least five members of this committee were social scientists. This committee had no officially recognized political status. Perhaps this is the reason that it reached more far-reaching liberal conclusions than the government-appointed committee known, after its chairman, as the "Baan Committee". The most striking fact of the second committee is, however, that its conclusions and recommendations were broadly accepted by the Dutch government as well as parliament, and that its recommendations to the present day have guided the practical implementation and execution of Dutch drug policies. In this respect Holland seems to be the exception to a general disregard that has typically been the fate of the advisory committees recommending decriminalization and relaxation of drug policies.

Because of its official status, the Baan Committee was, of course, the committee that really mattered. The more radical "Hulsman Committee" (named after its chair) was, however, influential because it was the first to finish its report, and because two of its members also participated in the official government-committee. This "Working Group on Narcotic Substances" (as the Baan Committee was officially named) had more high-ranking administrators of the ministries of public health and justice as well as penal law officials among its 15 members than the Hulsman Committee. Based on the differences in official status and composition of the two committees, one may speculate that the Hulsman Committee typically voiced the views of the traditional liberally minded social science and (mental) health professions, whereas the Baan Committee should in principle be considered to be more ideologically balanced. According to this logic a comparison between the recommendations of both reports may tell us how far a broad professional consensus about drug policies in Holland was removed from explicit permissiveness. 


\section{The Hulsman Report: Defining basic social attitudes}

The Hulsman Committee based its risk analysis of illegal drugs (compared to legal recreational as well as medical drugs) mainly on the dependency-producing potential of the substances (Stichting Algemeen Centraal Bureau voor de Geestelijke Volksgezondheid 1971). While stressing the potential dangers of opiates, amphetamines (no one in the Netherlands even thought of the possibility of cocaine becoming a problem, since this drug was virtually absent) and barbiturates, it relativized the pharmacological risks of cannabis "...tobacco undoubtedly has stronger addictive properties than cannabis" (p 19-20). It distegarded the "stepping-stone" thesis of cannabis which around 1970 was still seriously considered by stating that "...one of the most important causes of escalation from cannabis to other, more dangerous drugs is the fact that cannabis is included in the Opium Act" (p 53).

Sociologically it interpreted drug (cannabis) use as a subcultural phenomenon, controlled by and fitting into a certain lifestyle, which in a modern pluriform society should not be judged by the norms of the subculture of "respectable citizens". It reasoned that moral rejection and repressive social control measures based on such a biased view would result in the marginalization of those non-conformistic subcultures. This line of reasoning was specifically applied to interference by the state: "The government should not take a censuring position based on the fact that a certain behavior does not fit into the life-concept of those who are holding state-power" (Ibid. p 40). The report especially warned against the harmful effects of law-enforcement practices in this respect.

Philosophically the report is based on the principle that the state should refrain as much as possible from interference with behaviors that have consequences for the individual person only. Indeed, John Stuart Mill's famous maxim from "On Liberty", used to be quoted a lot in those days. According to the report this maxim should certainly apply to repressive social control measures: "Although it is highly probable that the smoking of cigarettes will yearly make thousands of victims in this country, it can't well be imagined that the state would take forceful action against the tobacco-smoker" (Ibid. p 39). The Hulsman Committee warned strongly against putting more than very little reliance on the penal law in controlling drug problems. It predicted that the threat of law enforcement would not only fail to deter people from engaging in vice (victimless crime) in their private life, it would for various reasons also fail to control the supply side of the drug market. When penal law action is considered, so they reasoned, its possible or actual benefits should al- 
ways be weighed against the costs, both in terms of money and law enforcement capacity, and in terms of the harmful social effects of law enforcement. Among the undesirable side-effects they mentioned the amplification of deviance and marginality of drug scenes; the symbiotic development of vigorous and violent specialized police forces and (organized) drug traffickers as opponents in an escalating war; and the gradual undermining of civil liberties and the legitimacy of penal law. In short, this early report on modern drug policy reasoned that law enforcement against the world of illegal drugs would be costly, would fail to really control the supply, would make the social and health problems of drugtaking worse than necessary, would reinforce the growth of powerful criminal organizations, and would undermine constitutionality.

One can hardly deny a certain amount of prophetic talent to the Hulsman Committee when the following citations from this almost 20-yearold report are compared to Wisotsky's more recent account of the results of the "war on drugs" in the US. (Wisotsky 1986) The commission contemplated on the risks of embarking on a predominantly repressive drugs-control policy: "The narcotic department of the police-force will develop into a big, well-trained and excellently 'armed' unit, which will have to be improved and increased permanently, to keep up with the never-ending escalation. The undoubtedly more vicious character of the drugs problem that will develop will deplete the administration of other options to react to the problem. The dealer of marihuana as we know him now will only survive as a memory of how it all started, in the romantic 1960 s and 1970s" (p 49). The commission specified the social risks of primarily relying on law enforcement, which it qualified as an "inadequate and therefore extremely dangerous" choice for drugs control: "This instrument will fail again and again, which will induce its proponents to further increase the repressive measures ... law enforcement, will increasingly have to intrude into the spheres of private life ... (which) ... will further the polarization between several groups in society and may thus lead to increasing violence" (p 51).

The policy recommendations that concluded the report of the Hulsman Committee were more radical than those of the officially appointed Baan Committee, yet they were not as radical as the rhetorics of this report might have suggested. Even the relatively fervent liberals of this committee chose a more pragmatic course when relating to the practice of the developing Dutch drug policy. We will compare the policy recommendations of the two committees after a brief description of the report of the Baan Committee, which had a decisive influence on the formulation and further development of drug policies in the Netherlands. 


\section{The Baan Committee: Defining basic social reactions}

The Hulsman Committee may very well have reflected the high tide of moral pluralism that dominated the Dutch social-cultural landscape around 1970, not only in the field of drug use but also in other areas of potential moral and social conflict. (Of course this was a much more general trend in the Western world.) Sexual morals and corresponding legal practices changed drastically. Homosexuality, abortion and pornography were more openly accepted. Traditional relations of authority (such as between the sexes and the generations) were seriously challenged. The same thing happened to religious and political power institutions. During that period one did not only see crowds of young American backpack tourists congregating on Dam Square or in the Vondelpark to openly share their joints, but also sex and abortion tourists from southern European countries, and on Friday-night crowded airplanes from London with gay people set out to partying in the gay bars of Amsterdam.

In this cultural climate the Hulsman Committee probably provided an ideological justification for the much more down-to-earth Baan Committee to break away from the single-minded prohibitionist regime that until that time had seemed to be the most natural Dutch (official) social policy approach to illegal drug use. The Baan Committee explicitly referred to the Hulsman report in its own policy paper, entitled "Background and Risks of Drug Use" (Werkgroep Verdovende Middelen 1972). Interestingly enough, the original assignment from the State Secretary of Social Affairs and Public Health to the "Working Group on Narcotic Drugs" was clearly phrased within this traditional prohibitionist's framework. It mentioned three main topics of concern. The first and the last were very briefly formulated as a study into the causes of the increasing use of illegal drugs, and the correct medical-social treatment of those addicted to such substances.

The second topic to be studied by the Baan Committee was more extensively qualified. It reads as follows:

"the counteracting of the irresponsible use of those substances by: (a) efficient criminal investigation of illegal trade channels; (b) efficient criminal investigation of and appropriate ways of dealing with users; (c) education on the dangers ... of use".

During the next two years the government, after discussion with parliament, broadened the working group's initial assignment, to give recommendations for social drug policy not necessarily within the prohi- 
bitionistic framework. The Baan Committee reached its final composition in 1970 and published its report in 1972. The conclusions of this report were almost completely adopted by the center/conservative government that was in office. A revised form of the strictly prohibitionist "Opium Act" (dating back originally to 1928) was ultimately developed by the center/left-wing government that took office in 1973. The revised Opium Act proposal was brought before parliament no earlier than 1976. The four-year time lapse between the development of the legal proposal and the ultimate passing of the legislation has probably been quite functional; the proposed decriminalization and relaxation of drug control were already introduced in social practice during this period. Consequently, the effects of the proposed law could first be tested in practice even before official new legislation was to be adopted. This was perfectly consistent with the committee's view that for the proper evolution of drug policy, frameworks for experimentation should be created. These experiments should be carefully evaluated: "... when sufficient faith in the safety of new positions exists, then the old ones can be left" (Ibid. p 74).

The Baan Committee did not indulge in philosophical or ideological digressions, but rather straightforwardly tackled two main issues. First, it debated whether or not a strictly prohibitionistic policy model should be retained for all drugs outlawed by the then existing national and international (Single Convention) legislation. Secondly, it tried to offer an outline for an integral social policy model in which diverse social (control) measures could be fitted. It specifically tried to link priorities of drug policy to available policy options such as repressive criminal justice measures, (psycho)-medical and welfare measures, education, and normalization.

The leading notion behind the recommended policy model of the Working Group was that the level of coerciveness and certainty of social reactions to using and trading drugs should be carefully linked to a riskanalysis of the kind of drugs and behaviors involved. According to this logic, the Working Group devoted special attention to cannabis and concluded that this substance should no longer be included in the category of drugs with "unacceptable risks". It argued that the social costs of criminal law repression of use and other-than-wholesale trade of cannabis would outweigh the possible benefits. In this concept of social costs, the committee included the dangers of unwarranted marginalization and fulfilling the conditions for the stepping-stone effect.

Before providing its final recommendations for the revision of the Opium Act, the report stated that "...penal law policy should take into account the more general aims of social drug policy" ( $p$ 67). General 
drug policy should, first and foremost, be aimed at primary and secondary risk prevention. In this context, the report stated that "...socially integrated use of drugs may be possible ... This does not mean that no risks are involved, but that those risks could be acceptable" (Ibid. p 66). Although phrased in different terms than the Hulsman Committee, the Baan Committee also rejected law enforcement as the main answer to the illegal drug problem. It put penal law policy in the context of general social drug policy, and it accepted the premise that particular forms of drug taking could be tolerated (and even integrated into society).

Both the Hulsman and the Baan committees stated their penal law reform recommendations in similar frameworks. They both distinguished between cannabis and the other illegal drugs, and they further distinguished between using and trading drugs. As mentioned before, the Hulsman Committee was most radical in its recommendations. It proposed that use of cannabis should be legalized and that trade of cannabis (on any level) should be made a misdemeanor which only would be punishable by a fine. This same legal status was proposed for possession and use of illegal drugs other than cannabis. However, dealing and trading in those drugs should remain a criminal offense. The Baan Committee recommended that use and "small-scale-trade" of cannabis should be made a misdemeanor. On the other hand, wholesale trafficking of cannabis (more than 250 gram) should remain a criminal offense, but there should not be a threat of imprisonment of more than one year. Using and trading other illegal drugs were proposed to remain criminal offenses. Although the Baan Committee stated that "...a penal law approach of drug users is inadequate" (Ibid. p 68), they also believed that in the foreseeable future this statute could not be missed as a possible means of exerting pressure on chronic users to seek treatment, and as a symbolic warning for prospective or experimental users.

In 1975 the new cabinet, in which the (more leftist) Social Democrats had replaced the Conservatives in a coalition with the Christian Democrats, introduced a revised form of the existing Opium Act to parliament. In this bill, the general recommendations of the Baan Committee had been translated into concrete provisions. The government provided three rationales for the proposed penal law reform: a more severe criminalization of the trade in amphetamines, a maximal separation between the trade in cannabis and the trade in drugs with "unacceptable risks" and, finally, the reduction from the status of criminal offense to the status of misdemeanor of the possession of cannabis for own use. After all was said and done, the revised Opium Act proposed by the government turned out somewhat less liberal than the Baan Committee had intended. 


\section{The parliamentary debate: Political acceptance of pragmatic policies}

In 1976 the proposed revised Opium Act was discussed in parliament. Although formally this was a penal law bill, its primary endorser was the Minister of Public Health, social democrat Irene Vorrink, the first member of cabinet responsible for its defense in parliament. The Minister of Justice, the Christian Democrat Dries van Agt, was the secondary endorser. He played a less important role in the bill's defense. This order reflects the central notion in Dutch social drug policy that drugs are, first and foremost, a public health and welfare issue, where criminal law and law enforcement is of limited and secondary importance.

The bill was passed by parliament, not without some passionate discussions, but almost unscathed, with the addition of two minor criminalizing provisions. The right-wing opposition - mainly Christian fundamentalist parties plus some members of the Conservative Party (VVD)

- ultimately voted against the bill. It was adopted by a large majority (approximately three to one), consisting of the left wing opposition, the majority of the Conservative Party plus the Social Democrats and the Christian Democrats. The latter two parties (the foundations of the coalition cabinet) unanimously supported the bill.

In spite of some individual disagreements, there was a remarkably broad acceptance of the central notion that the use of hard drugs is not a problem that should be controlled by criminal law. The members of parliament expressed an almost unanimous conviction that drug addicts should be helped or treated, and should not be targets for law enforcement. A spokeswoman for the Christian Democratic party went even further than the Social Democrats in asserting her preference for an eventual decriminalization of all drug use. The spokesman of a right-wing opposition party opposing the bill agreed with the government's view that the threat of criminal law against users of hard drugs should be moderate and only be used to put some pressure on them to seek treatment: "...there is a limit beyond which execution of punishment serves no reasonable end. This limit is reached when truly addicted people are concerned ... We favor medical treatment instead of criminal prosecution..." (Handelingen 1976:3021). He further seemed to imply (although he would not explicitly affirm) that addicts should be sent to mandatory treatment. The left-wing opposition also agreed with the depenalization of the use of hard drugs, but instead of forced treatment they advocated the possibility of medical prescription of heroin to addicts. There also was little disagreement about the proposed considerable increase of the 
maximum penalties for wholesale (international) illicit trafficking in drugs with "unacceptable" risks (i.e., hard drugs), although the Social Democrats and the other left-wing parties warned against the social risks of escalating the war against the drugs trade. The Minister of Justice acknowledged that such undesirable effects (e.g., more violence, more aggressive marketing tactics, higher prices and, consequently, more criminality) might occur. But that would be no reason not to fight more forcefully against the suppliers of illicit hard drugs, he stated. He added that a balanced two-track policy, aimed against the supply of and the demand for hard drugs would be necessary.

The opponents of the revised Opium Act mainly argued against it because of the proposed formal decriminalization of cannabis. This seems to indicate that this heavily symbolic issue was really the heart of the value dispute that the proposed new drug policy reflected. Generally, the opponents contested the government's conclusion that the individual and social risks of cannabis were "not unacceptable". A small and by now quite familiar battle of "scientific proofs" about the possible psychomedical and social harmfulness of cannabis raged in parliament. Only the two small religious fringe parties admitted their conviction that official "approval" of any kind of drug use was unacceptable for moral reasons. This argument was countered by Joop Voogd, the Social Democratic spokesman, who said he happened to possess in his house a 5-gram piece of cannabis "purely for curiosity's sake as I may reassure some of my colleagues" (Handelingen 1976:3067). He raised the question why young people with their recreational substance of preference should be vulnerable to the theoretical threat of four years of imprisonment, while alcohol, the functionally similar substance of "the silent majority", was not only accepted but even commercially exploited (Handelingen 1976:3067).

The Minister of Public Health asserted to the relatively small minority of principled opponents of the bill (i.e., those against the decriminalization of cannabis) the government's intention to eventually arrive at the complete legalization of cannabis. She did recognize, however, that this could only be done if the regulations of the international Single Convention were changed to allow a complete absence of criminal law provisions against cannabis. The minister declared that the Dutch government would try to encourage such modifications in the international treaty: "...that countries will be free to draw up their own national regime" (Handelingen 1976:3098). With regard to the possible medical and social risks related to the decriminalization of cannabis, she argued, first, that the vast increase in cannabis use had occurred during a period of no distinction between cannabis and other drugs, and secondly, that in the ab- 
sence of a clear indication of serious harmfulness of cannabis “...the final conclusion about the dangerousness of cannabis is not so much based on chemical or biological data, but more on our social evaluation of the substance" (Handelingen 1976:3096). Both ministers defending the proposed revised Opium Act asserted the important legislative principle that, in order to criminalize private behavior, the burden of proof of the unacceptability of such behavior should rest on the legislators. Apart from the main question of whether or not cannabis should be legalized there remained three controversial issues that were heavily contested: the 30gram limit, the "house dealer" and the "Stock Exchange Reports". In only one of these issues (the Stock Exchange Reports), was the government eventually beaten.

\subsection{The 30-gram limit}

There was some opposition against the supposedly too liberal allowance of the quantity of cannabis ( 30 grams) that could be possessed before it would be considered a criminal offense. The 30-gram limit was based on the sympathetic calculation that this would allow a personal supply sufficient for two weeks that would also enable users to share some stuff with their friends. Some skeptical representatives rightly assumed that this would protect small-scale cannabis dealers from serious law enforcement. The government wisely did not try to refute this argument, but said that such a consequence should be accepted. In fact, the later development of the "coffee shop" phenomenon was based on this arrangement. The spokeswoman for the Conservative Party submitted an amendment directed against the 30 -gram limit. It was rejected by a twothird majority.

\subsection{The house dealer}

Some animated discussions were devoted to the phenomenon of the so-called "house dealer". This is a person who is permitted by the staff and the board of a recreational or educational youth center to sell limited quantities of cannabis to the members and visitors of such a youth center. This practice had already been adopted by a small number of youth centers for some years, based on the recognition that their visitors were already in the habit of using cannabis as part of their recreational activities within the center. It had been noticed that some of them were attracted to other drugs and - consequently - that there was a substantial risk that dealers of hard drugs would try to develop a market in the youth center. 
The designation of a house dealer served to prevent the diffusion of hard drug use into vulnerable groups of adolescents. The parliamentary opposition against it not only pertained to matters of criminal law (as the house dealer would probably violate the 30 -grams limit), but also to the fact that those youth centers were fully funded by public means. Precisely at the time of the parliamentary discussions, criminal proceedings were taking place against a house dealer in the Hague. The Minister of Justice argued that the dilemmas involved in this case could not be solved by law or by a central policy. Decisions should be made by the law enforcement authorities who on the basis of the expediency principle could decide whether or not to act against a specific house dealer in specific circumstances. The minister acknowledged, however, that the house dealer could be very useful in realizing a central aim of Dutch drug policy, namely the separation of the markets and social contexts of hard and soft drugs. For this reason he said that "...law enforcement should take into account the interests of public health and welfare" when deciding about the legal position of the house dealer (Handelingen 1976:3116). In other words, law enforcement should refrain from interference with the institutionalized sale of cannabis (i.e., through the house dealer) for the benefit of society.

Shortly after the adoption of the new Opium Act the issue of the house dealer became a subject of practical drug policy consultation at local levels between administrative and law enforcement authorities. Since then no more house dealers have been prosecuted. The issue would have been forgotten completely, were it not that an overzealous administration of a city near the German border decided to officially appoint and license a local cannabis house dealer, someone who had already operated in that capacity informally for some years in one of their youth centers. This was more than the German neighbors of the Netherlands were prepared to take and it resulted in some political confrontations between both countries (Kaplan 1984).

\subsection{The stock exchange reports}

The government lost its battle over the last of the three most controversial issues of the cannabis policy. The dispute around the Stock Exchange Reports was symbolically highly charged. It concerned a weekly feature in a very popular radio-program for young people, broadcasted by the Social-Democratic network, one of the major public networks in the Netherlands. This feature gave information on drug issues. It often contained non-moralistic warnings against the risks of hard drugs. But, 
most importantly, it was in outright defiance of prohibitionistic attitudes in its candid publication of the market prices of the different brands of hashish and marihuana. The presentator and author of this feature was the chief editor of a flourishing "underground" magazine. He was often alluded to as "the emperor of the alternative youth culture". He succeeded in maintaining his popularity in the hippie population by expressing imaginative ideas; for instance, the replacement of the hothouse agriculture of silly tomatoes by some good breeds of Indian hemp. Not surprisingly, his popularity was rather low among more conventional circles of society. It was widely known that this young man was the son of the Minister of Public Health.

This issue shows where the broad consensus on more tolerance for the social phenomenon of cannabis use ended. Many representatives in parliament, even many who were in favor of the new decriminalizing drug policies, disapproved of the Stock Exchange Reports. They were deemed to be a blatant propaganda for drug use. Some members of the right-wing parties fulminated strongly against the program and asked for law enforcement actions, or, at the very least, that this program should be banned from the air. They were most appalled by the fact that the program always ended by referring to the homegrown weed variety as “...'Lowlands Weed', our national pride", which, to my memory, was a very optimistic qualification for something that smelled like smoldering hay and which brought about sore throats more than kicks. None of the indignant representatives, however, even tried to imply that the family relationship had anything to do with the position of the minister primarily responsible for the defense of the new bill. The spokesman of the Social-Democrats tried to counter the accusations against "his own" Social-Democratic network by insisting that the program was actually intending to educate and warn against drugs. This however did not stop parliament from proposing and adopting an amendment. Against the intentions of government, provision $3 b$ was added to the revised Opium Act, which made illegal "... any publication aimed at promoting the sale or delivery..." of all illegal substances. The Stock Exchange Reports however continued to be on the air some five more years. Then the feature died a natural death because of a lack of interest as the prices of soft drugs were beginning to be published on the "menus" of the coffee shops.

In June 1976, the new Opium Act was passed into law, with only minor alterations from the bill that was originally proposed to parliament. 


\section{Concluding remarks}

This brief history shows that, apart from a short period at the very beginning of the 1970s, the drug problem has hardly been a confrontational issue between moral/political left and moral/political right in Holland. As a matter of fact, this relative "neutrality" of Dutch drug policy has been maintained until the present day. The drug issue has not served as a means of promoting political or moral power, nor has it served the specific institutional interests of law enforcement agencies. Political speeches elaborating on the abhorrence of illegal drugs have seldomly been staged. They would appear as quite misplaced in the Dutch political culture. Consequently, there are no votes to be won or positions to be conquered by rallying on the anti-drug theme.

In a comparative analysis of the development of drug policies in the Netherlands and Western Germany it was concluded that "...a low degree of politicalization of the issue was the most important prerequisite for successful decriminalization" (Scheerer 1978:603). In the decisive years for setting the tone of drug policies, around 1970, the general public in both countries was assumed to be quite similar in its (moral) rejection of drug (cannabis) use. Thereafter, according to Scheerer, social policy reactions departing from this public attitude strongly diverged. In Germany, the political parties, the police and the medical profession used the drug issue to further their own institutional objectives by a process of problem amplification. A contrary process of de-escalating the significance of the drug problem relativation occurred in the Netherlands. The Social Democrats were allowed to realize their "liberal" interests in moral issues because their Christian Democratic partners in the coalition cabinet did not choose to use the drugs issue "as a self-serving sociopolitical symbol" (Scheerer 1978:595).

The Dutch revised Opium Act of 1976 reflects the settling of a value dispute over personal preferences and collective prohibitions. This compromise over moral values has allowed a pragmatic and cost-benefit oriented drug policy to be developed and implemented in the $1980 \mathrm{~s}$ and 1990s.

\section{References}

Advisory Committee on Drug Dependence: Cannabis. London: H.M. Stationary Office, 1968 Cohen, H.: Drugs, Druggebruikers en Drug-scene. Alphen aan de Rijn: Samson, 1975

Commission of Inquiry into the Non-Medical Use of Drugs: A report of the Commission. Ottawa: Information Canada, 1972 
De Kort, M.: De Problematisering van het Druggebruik in Nederland 1850-1940. Rotterdam: Erasmus Universiteit, 1989

Handelingen Tweede Kamer 1976 (Proceedings of the House of Representatives). Den Haag: Staatsuitgeverij, 1976

Kaplan, C.D.: The uneasy consensus, prohibitionist and experimentalist expectancies behind the International Narcotics Control System. Tijdschrift voor Criminologie 98-109, 1984

National Commission on Marihuana and Drug Abuse: Second Report of the National Commission on Marihuana and Drug Abuse. Washington DC: US Government Printing Office, 1973

Scheerer, S.: The new Dutch and German drug laws: social and political conditions for criminalisation and decriminalisation. Law \& Society 12:585-605, 1978

Stichting Algemeen Centraal Bureau voor de Geestelijke Volksgezondheid: Ruimte in het Drugbeleid. Meppel: Boom, 1971

Van de Wijngaart, G.F.: Competing Perspectives on Drug Use: The Dutch Experience. Amsterdam/Lisse: Swets \& Zeitlinger, 1991

Werkgroep Verdovende Middelen: Rapport van de Werkgroep Verdovende Middelen. Den Haag: Staatsuitgeverij, 1972

Wisotsky, S.: Breaking the Impasse in the War on Drugs. New York: Greenwood Press, 1986 


\section{ENFORCING DRUG LAWS IN THE NETHERLANDS}

Jos Silvis

\section{The historical and international background}

Occasionally, people seem to think drug policy has no history before the sixties. The actual shape and content of drug policy in most countries, however, has a direct link to the early days of this century. Moreover, the problematic relation of people with certain substances with psychotropic effects probably dates back a number of millennia. ${ }^{1}$

Drug policy in the Netherlands has some of its roots in its colonial past. The Dutch government used to have large monetary interests in the trading and consumption of opiate products in what is now the independent state of Indonesia. Though governmental intervention in that particular drug trade had a solid financial rationale, it was legitimated by the proclaimed goal of reducing drug consumption and production in order to protect the unfortunate addicted inhabitants of the colonies. ${ }^{2}$

This historical involvement in the struggle against drug misuse and the resulting knowledge about this problem is one explanation for the important role the Dutch played in the original international effort to universalize the repressive approach to (especially) narcotic drugs. Holland, together with China and the United States, entered into the agreement of Shanghai in 1909 acknowledging for the first time the need for an international approach to drug-related matters. Soon the earliest international drug treaty followed in the Dutch city of The Hague. The Treaty of The Hague (1912) established the foundation of the international legal approach to the so-called dangerous drugs. ${ }^{3}$

The historical background of the widespread participation of most countries in the drug treaties from 1919 on lies in a peculiar fact that has no direct connection with drug problems in the member countries, not even in their colonies. In fact, not many states signed the treaty of The Hague spontaneously. This changed quite dramatically when the First World War was ended by signing the Treaty of Peace 1919. Article 295 of the 1919 Treaty of Peace reads as follows: 
"Those, of the High Contracting Parties who have not yet signed, or who have signed but not ratified, the Opium Convention (...) agree to bring the said Convention into force and for this purpose to enact the necessary legislation without delay (...). Furthermore, for those Powers which have not yet ratified the Opium Convention, ratification of the present Treaty should be deemed in all respects equivalent to the ratification of that Convention (...)". ${ }^{4}$

Ever since this creative legal move, drug treaties have had more participating countries than any other "non-political" treaty. After the Treaty of The Hague many other drug treaties were initiated. This resulted in an international institutional framework that is currently anchored in the organization of the United Nations.

In 1961, an effort to replace all existing treaties with a single one resulted in the Single Convention of New York, which is still the primary legal document in the international cooperative effort against the socalled dangerous drugs. The Dutch are a party in this Convention as well as in the Amendment that followed in 1972. The Dutch hesitated for a long time, however, before they signed the convention of Psychotropic Substances, which was drafted in $1971 . .^{5}$ This hesitation was largely based on mere technical grounds. An interesting development occurred at a conference organized in preparation of the 1988 Vienna Convention on Illicit Trafficking where the Dutch Minister of Justice expressed full Dutch support for the international fight against drugs. Apparently, the initial objections against the treaty had withered away quite suddenly. By announcing that the Dutch had decided to adhere to the Convention of Psychotropic Substances, the Minister of Justice thus garnered the necessary credit to be considered a serious participant in the designing of the Vienna Convention. The focus of the Vienna Convention is on hurting drug traders and traffickers financially. ${ }^{6}$

Although the Netherlands was one of the early forerunners of the internationalization of drug policy, over the years it lost its leadership role in this regard. Gradually, the Netherlands became just one of the many countries that simply signed the treaties and acted loyally in the implementation of the agreements. International agreements form the (more or less freely accepted) external constraints within which a sovereign drug policy can be developed. The treaties (especially the Single Convention of 1961) may be quite strict in relation to the kind of legislation the member states should have, but in matters of daily criminal policy many options remain open. To a certain extent the international treaties have produced harmonious legislation all over the world; however, 
different types of policy are put into practice under similar criminal legislation.

Dutch drug policy has often been described as rather different from that of other Western countries. The following descriptive account of the role of the Dutch criminal justice system in Dutch drug policy will explain the Dutch approach to drug problems; focusing on the actual functioning of the criminal justice system will be more instructive than reading formal statements by diplomats or other representatives of the Dutch government on the background and rationale of the Dutch drug policy.

\section{Law-on-the-books and law-in-action}

In the Netherlands the distinction between "law-on-the-books" and "law-in-action" is remarkably clear with regard to drugs. ${ }^{7}$ Possession of marihuana and hashish is forbidden, ${ }^{8}$ but in virtually every town one can find coffee shops where consumers openly buy their illegal products without fearing interference from the police. ${ }^{9}$ Also, in the big cities one can easily spot the places where heroin and cocaine are sold, although this takes place in a more tense atmosphere. Here the police may suddenly show up and make arrests.

However, it is too simplistic to conclude - as the skeptical observer of the highly visible drug trade and drug use will be tempted to do - that there is no law enforcement at all in the Netherlands. Countries where drug users are less visible do not necessarily have a lower level of consumption or a better system of handling problems surrounding consumption. Painting the cities blue with law enforcement officers will certainly take away the visibility of drug problems but definitely not the drug-related problems as such.

Important is what police officers actually do and how they carry out their function. Legal documents may be an important factor in guiding the police and the prosecution in their behavior, but other factors are also important. ${ }^{10}$ This seems almost self-evident. Legal rules do not address the problem of limited resources such as personnel, cars, interrogation rooms, cells, and so on. When more cases are processed than the system can properly handle, mistakes occur and the criminal justice system derails. The criminal justice system must set priorities in order to prevent such a situation. This holds true for all countries, including those where the police and the prosecution are formally obliged to bring to court any crime that is detected (i.e., countries based on the principle of legality). 
Contrary to the principle of legality, which for example is incorporated in the German Code of Criminal Procedure, the Dutch have committed themselves to the principle of expediency (or opportunity) which formally allows discretionary powers to the police and the prosecution. ${ }^{11}$ The use of this principle of expediency is not limited to the necessity of setting priorities in order to cope with scarcity of resources. In fact the main function of the principle of expediency is to prevent prosecutions that are not in the best public interest. Originally, this legal principle gave prosecutors an almost unlimited degree of personal discretion, but presently there are officially published guidelines on how to deal with certain cases under specified conditions. (See discussion in section 4 of this Chapter.) These guidelines bridge the gap between the law-on-thebooks and the law-in-action, particularly with regard to illegal drugs.

\section{The Opium Act: law-on-the-books}

The current Dutch Opium Act dates back to 1928; however, many changes have taken place since. Only the name and some of the scheduled drugs remind us of the original document. The Opium Act of 1928 replaced the first Dutch legislation on illegal drugs that came about as a consequence of an international treaty in 1919. Prior to that there was only an 1885 statute, which curiously enough limited the sale of opiate products in amounts of less than $\mathbf{5 0}$ gram to medical practitioners and pharmacists, allowing everybody else to deal in larger portions.

Originally the Opium Act was a piece of health legislation. In some respects it still is, for instance by allowing the Minister of Health to license persons and institutes to prescribe particular drugs. A license to prescribe legally forbidden drugs is only provided if justified by scientific or medical goals. The Minister makes these licensing decisions, but the initiative to start such a program (i.e., to prescribe legally forbidden drugs) is often taken at the local political or administrative level. 12

Though originally the Opium Act may have been health legislation, today it is viewed primarily as criminal legislation. There is no question that this Act satisfies all demands of the international conventions, stating the punishability of possession, trade, cultivation, importation and exportation and a number of other acts and omissions in relation to narcotic drugs (including cannabis products).

Depending on whether the drugs are listed on schedule 1 or schedule 2 of the Opium Act, the law specifies different sanctions. The mildest approach is toward the drugs on schedule 2 . This list only contains cannabis products. On schedule 1 one finds drugs such as heroin and co- 
caine. According to the explanatory report accompanying the Opium Act the government considered the drugs on schedule 1 to be an "unacceptable risk". Cannabis products on the other hand were not considered to involve unacceptable risk. The maximum punishments for acts and omissions in relation to the drugs on schedule 1 are much harsher than for the drugs on schedule 2 . In fact the differentiation reflected in the schedules parallels the well-known distinction between soft and hard drugs. On schedule 1 you find "hard drugs" (heroin, cocaine, LSD, etc.) and on schedule 2 you find only hemp and derivatives of hemp like cannabis. A technically odd feature of the two schedules is that tetrahydrocannabinol (the working substance of hemp and cannabis) is listed on schedule 1. Tetrahydrocannabinol as well as cannabis resin are considered hard drugs (i.e., drugs with unacceptable risk) when they are found in a form other than the "normal soft drugs" of schedule 2 (i.e., marihuana, cannabis, hashish, esrar, chiras and djamba, all customary solid mixtures of cannabis resin to which no other substances have been added). These "sloppy" definitions of tetrahydrocannabinol and hemp products on the schedules of the Dutch Opium Act are theoretically quite unsatisfactory, but in practice this has never caused any problem.

Since the Dutch hemp production is of growing significance, we need to comment on the peculiar position of hemp growing in the Netherlands. The Opium Act forbids the growing of hemp unless it is to win seed, to shield gardens from the wind, or for industrial purposes like the production of rope. In practice it is hard to clearly establish the purpose of growing hemp. It is generally acknowledged that, under the umbrella of the above-named exceptions, the growing of hemp for drug recreational purposes has been flourishing for over ten years. The quality of Dutch hemp is the best in the world according to drug users: tetrahydrocannabinol levels of more than $30 \%$ are found (maximum measurement: $37 \%$ ). In comparison: Moroccan hemp usually gives a tetrahydrocannabinol level in the range of $6 \%$ to $15 \%$. The national production of hemp makes it possible for the Dutch to provide the coffee shops to a large degree with home-grown products. Though it is relatively easy to make hashish out of Dutch hemp, research shows that there is little Dutch hashish on the consumer market.

Another important distinction in the Opium Act is between suppliers and consumers of illegal drugs. Use of illegal drugs per se is not directly punishable under Dutch law, but possession for use is. The relatively low legal priority on cannabis enforcement is reflected in the maximum level of punishment for possession of small amounts of cannabis. Theoretically, a maximum of one month imprisonment is possible for possession 
of up to 30 grams. But in practice there usually is no punitive reaction at all. If there is any punishment, it is generally no more than a small fine or a simple discharge. The relatively privileged position of cannabis products in Dutch legislation is the result of the historical compromise between proponents of legalization and the government which feared international reaction to legalization. As mentioned earlier, punishments for crimes relating to the drugs on schedule 1 are much tougher. A trafficker of heroin or cocaine or any other drug on schedule 1 faces a maximum punishment of 12 years imprisonment with the possibility of accumulation of punishment to a maximum of 16 years.

The Dutch Opium Act with its distinctions between cannabis products and other illegal drugs has been in effect since 1976. The last significant change of the Opium Act took place in 1985 with the introduction of the criminalization of any preparatory act relating to serious drug offenses (such as importation). In Dutch criminal law, the preparation of crimes other than drug-related offenses is not criminal unless there is a beginning of execution of the intended crime. The criminalization of preparatory acts in relation to drug crimes makes it easier for the police to use their powers in a pro-active manner. On the other hand, this possibility of early intervention makes it more likely that police activities intrude into everyday life. Also, the risk of legal errors is greater when the law covers preparatory acts that also might serve quite legitimate undertakings. Though the criminalization of preparatory acts is limited to operations related to the drugs on schedule 2 ("hard drugs"), the prosecution has developed techniques by which mere preparation of drug offenses involving cannabis (schedule 1 drug) may also be dealt with under legislation related to participation in forbidden organizations (paragraph 140, Dutch Penal Code).

\section{Guidelines for law in action}

The Opium Act may give some idea of the priorities in Dutch drug legislation, but it does not reflect, of course, the actual practice of drug law enforcement. In the Dutch legal system prosecutors are hierarchically placed above the police, they can give orders to implement a certain enforcement policy. In order to harmonize drug law enforcement in the different regions, the prosecutors of the High Courts produced guidelines for law enforcement and prosecution of drug crimes. ${ }^{13}$ Although more accurate than the Opium Act, these guidelines also do not describe actual practices. The guidelines are a kind of pseudo-legislation, intended to guide officials, rather than clearly defined legal rules for citizens. 
According to the guidelines, controlling the hard drug trade should have a high priority among police and prosecutors. This should be implemented by specialized law enforcement agencies, consistent prosecution policies, pretrial detention, and clearly specified sentences (minimal three years for dealers; two years for traffickers). In judicial practice, several criteria - such as the magistrates" "kilo policy" for importation traffickers in which prosecution demands one year per kilo hard drugs, up to the maximum of 12 years - have gradually developed. Personal circumstances ("how much did they know about their role in the illegal transport?") of individual traffickers are not very relevant in such a policy. This particular practice was never written down as an official guideline and ultimately did not survive criticism: it disappeared as quietly as it had appeared.

With regard to cannabis, the guidelines create a certain form of $d e$ facto decriminalization consisting of an officially agreed upon non-intervention in the retail market of cannabis under certain circumstances. This includes the practice of the so-called house dealer in the controlled setting of youth centers. Such agreement not to intervene may be made by the police, the prosecutor and the mayor in their regular discussion of what kind of criminal justice policies to pursue in a town or region. This system of triangular consultation allows the flexibility necessary to integrate the policies that flow from different responsibilities of the three parties involved (e.g. the partly conflicting interests of law enforcement, public order and public health). Though the guidelines only recognize the legitimacy of the house dealer phenomenon in youth centers, most deliberations have resulted in accepting cannabis dealing in coffee shops. In some cases the courts have acknowledged that prosecution of cannabis dealers in coffee shops should not be encouraged as long as they act according to a number of negative criteria, like ${ }^{14}$ :

- not selling to youngsters who are under 18 (in some towns: 16) years of age; not promoting the business by advertisements;

- not selling in other than small amounts; not selling other illegal drugs;

- not selling to foreigners;

- not causing other public disturbances.

Whenever disturbances take place on a regular basis in a coffee shop, typically the local government takes administrative action in order to close the coffee shop. ${ }^{15}$ The fact that soft drugs are involved has appeared to be irrelevant to Dutch administrative courts. ${ }^{16}$ Local government is not allowed to close a shop or pub merely because of the retail trade in soft drugs. This socio-legal practice which has developed over 
the last 15 years shows that use and selling of cannabis products has gained a pseudo-legal status in the Netherlands, in spite of the Opium Act, which defines cannabis possession as a minor misdemeanor and drug dealing as a felony. At this point a closer look at the legal construction of allowing dealing in coffee shops may help explaining the somewhat confusing concept of a pseudo-legal status.

There are about 1500 coffee shops in the Netherlands where soft drugs may be bought. ${ }^{17}$ How is that practice reconcilable with international obligations? The Single Convention and the obligations of the Illicit Trafficking Convention of 1988 do demand criminalization of possession, trafficking, dealing, cultivating and producing of soft drugs as well as of hard drugs. This obligation is met in Dutch legislation in the Opium Act. But there are no clauses in the relevant UN drug conventions that concern the actual enforcement of the legislation. The Single Convention acknowledges explicitly that enforcement of statutes may be limited on the basis of principles that are a fundamental part of a nation's sovereignty. This clause provides the latitude the Dutch have been using in their drug policy: by interpreting the legal principle of expediency as a fundamental sovereign principle, the Dutch have been able to develop a policy of (partial) non-enforcement of violations of the Opium Act. The expediency principle includes the discretionary powers of the prosecution (paragraphs 167 and 242 of the Criminal Procedure). The Dutch Supreme Court demands a degree of consistency in the use of discretionary powers. Earlier we referred to the guidelines for law enforcement and prosecution of drug crime produced by the prosecutors of the Courts of Appeal. These guidelines are intended to structure the use of discretionary powers of the prosecution in a consistent manner. According to the Dutch Supreme Court, a practice that follows these prosecutorial guidelines in a consistent manner has the status of "law". The guidelines explicitly allow the presence of a soft drugs dealer in youth centers. The guidelines imply that decisions concerning enforcement of drug laws are to be made at the local level through regular deliberations between the mayor, the prosecutor, and the police. Although the coffee shops are not dealt with in the guidelines, case-law based on Dutch Supreme Court decisions states that a consistent practice, even if not formally included in prosecutorial guidelines, also obtains the status of "law". Thus, "practice" creates new laws.

Because coffee shops have been consistently tolerated since the late seventies in most parts of the Netherlands, now a specific motivation is required to successfully prosecute dealing in soft drugs in a coffee shop. ${ }^{18}$ This specific motivation could be that certain conditions which 
guide the acceptance of coffee shops in most parts of the Netherlands are not met in the coffee shop under scrutiny. As a consequence of the way in which coffee shops have become accepted, it is likely that other forms of dealing in soft drugs eventually may gain a similar pseudo-legal status. An example may already be found in the case of a "blow-home-courier-service" where a person had organized a local delivery service for cannabis users. He distributed small amounts of cannabis in the region of 's Hertogenbosch. ${ }^{19}$ According to the court the prosecution had no adequate justification for prosecuting this particular person in view of its overall lenient policy in soft drug matters. The prosecution lost this case. ${ }^{20}$

In spite of these developments, it must be noted here that legal evolution towards tolerance is by no means inevitable. Legally it is very well possible that a gradual retreat from the earlier policy of tolerance may take place. Mounting external pressure on the Dutch government may be an important factor. Partners in the Schengen Agreement have legitimate grounds to challenge Dutch drug policy, because the Schengen Agreement not only demands repressive legislation but also repressive practice in relation to soft drugs (Article 71). On the other hand, the Schengen Agreement also acknowledges respect for national sovereignty (Article 72).

Let us return to the guidelines. Though a low priority is given to the prosecution of possession of cannabis products, it may happen that a person gets caught with it. What will happen? The guidelines state that when an individual is caught with cannabis products for private use, it is possible to prevent prosecution through a transaction of 50 guilders (approximately US $\$ 25$ ). The guidelines set 30 grams as the maximum amount one can possess for private purposes, but in practice prosecution virtually never takes place for possession of less than 50 grams; even at this level $90 \%$ is not prosecuted. ${ }^{21}$ The police are not asked to take any pro-active initiatives to detect possession of small amounts of cannabis for private use. When larger amounts are involved, imprisonment becomes more likely, in particular for possession of one kilo (or more) of cannabis. According to Rook and Esser's study of the prosecution of drug-related offenses, seventy-seven percent of people convicted of possession of less than one kilo of cannabis only received a fine.

The tolerance shown for use of and trading in soft drugs is partly extended to hard drugs (e.g., heroin or cocaine). Users of these drugs do not have to fear direct intervention by the police in search of drugs. This is also a consequence of the guidelines, which give low priority to investigating possession of small amounts of hard drugs for private use. As a matter of fact, actual sentences for possession of up to 10 grams of heroin (or other "hard" drugs) are considerably below the guideline term of one 
year. However, importation or exportation of illegal drugs is met with a more strict enforcement of the law.

In spite of the restrained approach of law enforcement toward illegal drug use, many drug users are prosecuted because they come in contact with the police for ancillary crimes (shoplifting and other thefts, robberies, burglaries and so on). According to the prevailing law enforcement philosophy, drug addiction is not to be considered an excuse or a mitigating circumstance for cases of secondary criminal involvement.

Differently, the guidelines of the prosecutors explicitly recognize that a medical or socio-medical approach is preferred for people who violate the rules with regard to possession for private use. The guidelines are more than empty words; they are supported by a strong network of drugrelated social services. Be that as it may, still a large percentage of the prison population is addicted to drugs, which shows that the Dutch intention to deal with drug dependents primarily outside the criminal justice system is not altogether successful.

\section{Consequences of a criminal justice approach}

Clearly, the Dutch criminal justice system shows considerable flexibility in dealing with the drug issue. However, the picture would not be complete without an examination of the consequences of current law enforcement policy on (1) the drug market and drug use, and (2) on the criminal justice system itself.

The impact of the Dutch emphasis on attacking the supply side of the drug trade on the drug market is quite similar to the effect of such approach in other countries. ${ }^{22}$ The drug prices for consumers are, without a doubt, considerably higher than would be the case in a non-intervention market. The exact nature of the impact of criminalization of drug trafficking on the price of drugs is unknown; the proposition that drug prices follow a $\log$ function (i.e., 10 times as much in the town as on the field in the country of cultivation, ten times as much on the boat as in the town, and 10 times as much for the users in the place of destiny) at least has the credit of elegance and some self-fulfilling truth (even dealers read books). It is a well-documented fact that drug use in the illegal market brings about ancillary crimes of a secondary nature (i.e., a variety of criminal acts to raise money to buy drugs). Furthermore, the circumstances of drug use in an illegal context - despite the many assistance services available in the Netherlands - are still more risky than they would be in a legal context where there is no need to conceal use. In fact, to a large extent Dutch drug-related social services do no more than 
try to remedy the negative effects of the illegal context in which use takes place, rather than the negative effects of use itself.

The criminal justice approach definitely has an impact on the illegal drug trade. The high-risk/high-profit characteristics of a black market enterprise are, of course, an outgrowth of a repressive law enforcement approach to drug trade. This brings along a system of money laundering, firms that function merely as a front to cover up illegal activities, corruption in banking, bribery of police and customs and so on. ${ }^{23}$ In similar fashion, the illegal nature of drug dealing encourages the use of violence by operators in the drug market. These effects are of a general nature and by no means specific for the Dutch situation. Although the intensity of these effects may differ from one country to the other, they exist worldwide.

A repressive (i.e., criminal justice approach) to illegal drugs has also consequences for the functioning of the criminal justice system. The peculiarities of enforcing drug laws cause concrete problems in police investigations. Drug crimes are essentially victimless crimes; under normal conditions nobody is interested in informing the police of knowledge concerning drug transactions. This necessitates some forms of infiltration, or the buying of information; the police must rely on deception, and deal with informants with questionable credentials. Another problem is that drugs are relatively easy to get rid of when things get hot. Consequently, the police needs to move fast to "freeze" situations. Hazardous events, like crossing borders, are foreseeable and dealers have many means of shifting risks to naive or innocent traffickers. Even in the relatively low-key drug policy approach of the Netherlands, the fight against drugs has, occasionally, had a destructive effect on constitutional safeguards. This erosion of due process is based on the misleading but persistent notion that procedural safeguards frustrate the fight against drugs. It is misleading because a criminal justice system that shrinks away from due process is threatened in its very existence. In the next section, I will elaborate on this point by discussing a few Dutch Supreme Court cases related to police powers and drug users.

\section{Police powers and drug users}

As stated before, the Dutch fight against illegal drugs is primarily directed at the dealers. That has been the official policy from 1976 onwards. Nonetheless, many cases in Dutch courts are about possession of relatively small amounts of drugs. In order to search a person, Dutch law demands objective individualized grounds for suspicion; however, in the 
case of drugs, the mere presence in a place generally known for drug use and dealing provides sufficient grounds to allow the police to search anyone at that particular location (Ruimte, HR 14-1-1975, NJ 1975, 207). This may bring about searches at public places like railway stations, where drug users regularly hang out. This move from individualized to generalized suspicion is a major breakthrough in norms of criminal procedure. The search and arrest of drug users is not an aim in itself, but allows the police to gather information about dealers. Many drug users are under some sort of permanent suspicion and can be taken from the street any moment the police has time and energy to do so. When several statements from drug users implicate a certain person as a dealer, according to the Supreme Court it is no longer necessary to find drugs in the possession of this suspected dealer to obtain a conviction. In this way, again, the normally required objective grounds for suspicion and prosecution are reduced to a minimum, which opens the risk for manipulation of the criminal justice system. Though some drug users are under permanent suspicion when search and arrest are involved, in other situations it suddenly appears expedient not to view them as under suspicion (e.g. when the police questions them in the street without first cautioning about the right to remain silent (HR 29-9-1981, NJ 1982, 258)).

At the same time that the police appears to get more power with regard to drug-related activities, officers show a growing reluctance to arrest drug users, either for public order reasons or for trying to use their information to arrest dealers. Given the spread of the HIV virus among drug users, physically searching these people is considered to be hazardous. Moreover, it brings little job satisfaction to push the same unfortunate young people through the revolving door of the criminal justice system time and again. Therefore, many police officers favor some form of medically controlled prescription of drugs.

\section{Police powers and dealers}

Specific characteristics of the fight against illegal drugs make it necessary to employ "creative" investigative means, because of a lack of spontaneously reported information on drug-dealing to the police. ${ }^{24}$ In 1979, the Dutch Supreme Court established a number of conditions for the operation of undercover agents. An undercover officer may not incite anyone to commit drug crimes unless the person involved was already predisposed to do so. The presumed predisposition of a person is based on his criminal record and on facts drawn from the operational reports of the undercover agent (HR 4-12-1979, NJ 1980, 356). 
An undercover agent need not be a Dutch policeman. As a matter of fact, in the Supreme Court case just mentioned the undercover was a US DEA agent, with official diplomatic protection. Undercover agents normally work in a special task force for short-term infiltration. They seek to buy drugs, preferably in large amounts, and to arrest on the spot. Normally the Public Prosecutor agrees in advance on the type of procedure the task force follows; however, retroactive acceptance may also be sanctioned by the court. In a number of cases the undercover agent operates in connection with anonymous sources; the reliability of these sources is underscored by the sustained reputation that such a source has as a police informant. This is rather paradoxical, as it is hard to grasp how such a source can function for a prolonged time period without some foul play, which in turn would undermine the presumed reliability.

The position of anonymous informers and witnesses in Dutch law has come under attack as a consequence of rulings of the European Court of Justice. Accepting statements of anonymous witnesses as evidence of legal guilt may run contrary to the provisions of fair trial (Article 6 (1) and (3)(d)) of the European Convention for Human Rights): Unterpertinger, Kostovski. ${ }^{25}$ But as long as the anonymous informers can be used by the police without formally using their statements as legal evidence, then there is no restriction to do so. In the Brandstetter case, ${ }^{26}$ the European court suggested that the identity of the witness could remain a secret as long as the defense did not seek to question him or ask for his presence in court, and his testimony was of only minor evidential value. In the Lüdi case, ${ }^{27}$ the European Court of Justice was more open to the possibility of allowing anonymous statements of undercoveragents in drug cases as evidence, but only if the defense maintains the right to cross-examine the witness (provided this can be done in a way that protects the identity of the undercover agent).

Because of the specific difficulties in gathering information about drug dealing, tapping telephones has a growing popularity. More than $50 \%$ of the telephone taps in the Netherlands are related to drug investigations. Very often these taps are used in a prospective manner and not as a means to solve cases that have already occurred. This makes sense, since dealers are not likely to evaluate past transactions by phone; however, constitutionally the Dutch police should only use phone taps as a tool for solving (not preventing) crimes.

There are times when ordinary citizens have the duty to inform the police of suspected drug dealing activities; if they fail to do so they run the risk of being considered a participant in a drug crime. The Supreme Court made this ruling in a case against a taxi-driver who went 60 miles 
from Rotterdam (the Netherlands) to Antwerp (Belgium) at night in order to pick up a person from a boat. The person who had asked for the taxi from Rotterdam had some boxes and sacks with him. The taxi-driver did not inquire about the content of the luggage. When customs and police caught them on the way back to Rotterdam, the taxi-driver stated he did not know that his passenger was transporting illegal drugs. In spite of this defense, the taxi-driver was convicted for "culpable trafficking". The court ruled that the defendant should have considered the fact that his passenger was a foreigner with unconventional luggage in the context of the general knowledge that foreigners use taxi-drivers for illegal transports. Based on this general knowledge, he should have inquired about the content of the luggage. ${ }^{28}$

This case not only reflects an expansionist dynamic in criminal justice when drugs are involved, but also a discriminatory bias toward ethnic groups. That last aspect is shown in other cases as well. The Dutch Supreme Court has decided that contact between a "German white and a Dutch black person in the Warmoesstraat Amsterdam" may serve as a ground for police action on the suspicion of drug dealing (HR 6-121983). This case illustrates the discriminatory character of police actions against the drugs trade.

As the above examples illustrate, the Netherlands has not been exempted from the gradual retreat from the norms of due process resulting from the criminal justice fight against illegal drugs. ${ }^{29}$ And yet there is no indication that this has contributed to solving drug problems.

The willingness of the Dutch courts to expand police powers in fighting drug crimes has met with very limited success. Illegal drugs keep coming in, just as drug dealing keeps going on. Therefore, the police continue to ask for more powers, more financial means and a wider definition of what is a (drug) crime. This has already brought about legislation on the punishability of preparatory acts related to drugs. This 1985 legislation makes it possible to prosecute those who organize drug deals from a distance (with money and contacts) but who manage never to actually get caught with any drugs in their possession. The most recent proposal involves laws to punish dealers financially; legislation on money laundering and confiscation of illegally obtained proceeds (especially from drug dealing) is in preparation.

Our discussion of the impact of drug enforcement on the functioning of the Dutch criminal justice system suggests an analogy with its effects on drug-related social services. The relevant Dutch service agencies mainly work to redress the negative consequences of the illegality of drug taking; similarly, the criminal justice system mainly focuses on the 
confiscation of the profits that came about as a consequence of the illegality of drugs. It appears that some form of legal availability of currently prohibited substances would solve many problems, just as it inevitably would also bring about new problems.

In this context it is interesting to note that a remarkable number of people in strategic positions in Dutch criminal justice drug policy have spoken out for radical decriminalization of currently illegal substances. ${ }^{30}$ For instance, the Chief of Police of Utrecht, one of the largest cities in Holland, is a strong supporter of complete legalization of all drugs. His view is that the supra-national war on drugs has generated a multiplier effect in crime rates. ${ }^{31}$ Some members of the judiciary have also been outspoken about the destructive effects of the law enforcement approach to drugs. The vice-president of one of the District Courts has repeatedly and publicly stated that the current criminal justice approach is a disaster. "We are trying to win the fight against drugs the wrong way", he said addressing a conference on drugs. He did not come to this conclusion by reading scientific material on the drug war, but by observing the daily practice of criminal justice. ${ }^{32}$ During this same conference, a high-ranking official in the Ministry of Justice proposed to deal with drug offenses through administrative (instead of criminal) law. ${ }^{33}$ Finally, the solicitorgeneral of the Dutch Supreme Court has argued that the criminal justice approach to drugs has no serious future and may very well dissipate quite suddenly, just like the Berlin Wall. ${ }^{34}$

\section{The effects of European harmonization}

The effects of international developments on Dutch drug policy are discussed in Chapter 13 (Blom and Van Mastrigt). Therefore, we will only very briefly touch on some issues related to the current trend in the direction of European unification. The European economic and political integration has undoubtedly already had consequences for drug policy in Holland, though there is a debate on its actual significance. Some argue that European integration leaves enough discretion for the Dutch to go their own way. Others think this optimism is unjustified, and I do agree with them. Germany and France are hard liners on the drug issue, even where cannabis is concerned. Whenever Dutch drug policy could have any potential effect in Germany or on German citizens, German officials will remind the Dutch government of its obligation under the Schengen Treaty. In anticipation of such pressure Holland is already preparing for a harmonization of drug policy. Recently, the Dutch government endorsed a study which suggested giving priority again to the arrest and 
prosecution of persons in possession of small amount of soft drugs, especially when involving so-called drug tourists. But drug tourists do not only come to Holland for its permissiveness. They are sometimes motivated to come to the Netherlands because of lack of primary care facilities in their home country. The types of easy available services for drug dependents in the Netherlands (methadone programs, needle exchange) as well as the relatively mild punishments for drug crimes have been criticized by some of the other European countries. It seems unlikely that other European countries will open their borders without demanding adjustments in Dutch drug policy to make it more consistent with the European context. On the other hand, there are also indications of a contrary development, a shift from debating drug policy in an ideological manner to debating it in pragmatic terms. There are some indications that European drug policy harmonization will increasingly focus on the limitation of risks, as regards the health situation of users, the level of use, and the spread of AIDS in relation to drug use and prostitution. An international shift from ideology to pragmatism may save the peculiarly effective permissiveness that characterizes the Dutch criminal justice system, at least in some respects.

No one can claim to have the final solution to problems surrounding illegal drugs, but there is a growing understanding in the Netherlands that repression (even when it is focused on hard drugs) is not the most pragmatic option for drug policy. Unless, of course, one simply wants to stick to an internationally well-established habit.

\section{Endnotes}

1. Social and cultural aspects of drug use and historical origins of the use of opium. In: Chatterjee, S.K. (Ed.), Legal Aspects of International Drug Control, p 3. The Hague/Boston/London: Martinus Nijhoff, 1981.

2. Meijring, J.H.: Recht en Verdovende Middelen. The Hague: VUGA, 1974.

3. Stein, S.D.: International Diplomacy, State Administrators and Narcotics Control: the Origins of a Social Problem. Hampshire, UK: Gower Publ, 1985.

4. Similar provision may also be found in: Article 230 of the Treaty of Peace with Hungary, dated 4 June 1920; Article 174 of the Treaty of Peace with Bulgaria dated 27 November 1919; and Article 280 of the Treaty of Peace with Turkey dated 10 August 1920 . See Chatterjee, S.K.: Legal Aspects of International Drug Control, p 67; Endnote 1.

5. Convention on Psychotropic Substances of 21 February 1971 (Geneva). 
6. United Nations Convention Against Illicit Traffic in Narcotic Drugs and Psychotropic Substances, 19 Dec. 1988, UN Doc E/CONF 82/15. See: Chief Bassiouni, M.: Critical reflections on international and national control of drugs. In: Den Int'L \& Pol'Y Vol. 18:3, pp 311-337, 1990; Stewart, David P.: Internationalizing the war on drugs: the UN convention against illicit traffic in narcotic drugs and psychotropic substances. In: Den Int'L \& Pol'Y Vol. 18:3, pp 387-404, 1990; DeFeo, Michael A.: Depriving international narcotics traffickers and other organized criminals of illegal proceeds and combatting money laundering. In: Den Int'L \& Pol' $Y$ Vol. 18:3, pp 405-415, 1990.

7. See for this distinction: Van Dijk, J., Haffmans, C., Rüter, F., Schutte, J., Stolwijk, S. (Eds.), Criminal Law in Action. An Overview of Current Issues in Western Societies. Arnhem: Gouda Quint, 1986. In relation to drugs in that collection: Rüter, F.: Drugs and the Criminal Law in the Netherlands, pp 147-166. See also: Downes, D.: Contrasts in Tolerance. Post-War Penal Policy in the Netherlands and England and Wales. Oxford: Oxford University Press, 1988.

8. Opium Act Section 3.

9. See about the coffee shops in Amsterdam: Jansen, A.C.M.: Cannabis in Amsterdam. A Geography of Hashish and Marihuana. Muiderberg: Coutinho, 1991.

10. Not a recent phenomenon, see Emsley, C.: Policing and Its Context, 1750-1870. London: MacMillan, 1983. See also Davis, K.C.: Police Discretion. St. Paul, MN: West Publ Co, 1975; Stead, P.J.: Pioneers in Policing. Montclair, NJ: Patterson and Smith, 1977; ReussIanni, E.: Two Cultures of Policing: Street Cops and Management Cops. New Brunswick, NJ: Transaction, 1983; Toch, H. and Douglas Grant, J.: Police as Problem Solvers. New York: Plenum Press, 1991, especially Ch. 12: A Problem-Oriented War on Drugs.

11. A recently proposed change in the German Narcotic legislation (paragraph 31) introduces the expediency principle for the prosecution in a range of drug crimes. The German parliament has accepted the proposal.

12. A recent example: In September 1992 the Rotterdam police and the City administration announced that a heroin prescription program was being considered for a small group of "addicts". The execution of such a program is nonetheless the full responsibility of the medical doctor who ought to decide on medical criteria.

13. The official document is called: Richtlijnen voor her opsporings- en strafvorderingsbeleid inzake strafbare feiten van de Opiumwet (Strct. 1980, 137).

14. Arr. Rbank Groningen 11 December 1986, see: Silvis, J.: Kroniek rechten en criminologie. In: Tijdschrift Alcohol en Drugs 13(2):59-60, 1987. Arr. Rbank Zutphen 2 mei 1986, NJ 1986, 667.

15. An example of such action is a decision by the Dutch Supreme Court (November 25 1985 ARB 1986, no. 248). The court stated that direct intervention by the local authorities in order to close the coffee shop is allowed in cases where there is a direct threat to the quality of life in the neighborhood of a coffee shop where soft drug dealing takes place. In this case soft drugs were being sold to very young children.

16. The Court has decided that dealing soft drugs in a coffee shop is not necessarily detrimental to the living conditions in that neighborhood (Afdeling Rechtspraak van de Raad van State 8 May 1984 (Arb. 1984, 442).

17. Cannabisverkooppunten in Nederland, NIAD, Utrecht 1991.

18. HR 12 Juni 1990, NJ 1991, 44; HR 5 maart 1991, NJ 1991, 694.

19. Rechtbank 's-Hertogenbosch (Politierechter) 16 april 1992, Parketnummer 01/023997/91: distributing soft drugs by car is not substantially different from selling soft drugs in a coffee shop. 
20. The prosecutor has recently re-opened the case against the same person on similar grounds. Either the prosecutor has reason to believe that the court has changed its opinion, or the prosecutor has decided to fight the case through to the Appeal Court and perhaps to the Supreme Court.

21. These statistics are drawn from a study of A. Rook and J.J.A. Essers about the period 1977-1982, published in 1988 (Vervolging en Strafvordering bij Opiumwetdelicten, Staatsuitgeverij, 1988).

22. Körner, H.H.: Betäubungsmittelgesetz, München: Verlag C.H. Beck, 1990; Caballero, F.: Droit de la Drogue, Paris: Dalloz, 1989; De Choiseul Praslin, C.-H.: La Drogue: Une Économie dynamisée par la Répression, Paris: CNRS, 1991; Albrecht, H.J. and Van Kalmthout, A.M.: Drug Policies in Western Europe, Freiburg: Eigenverlag Max-PlanckInstitut, 1989.

23. De Choiseul Praslin, C.-H.: La Drogue: Une Économie dynamisée par la Répression, Paris: CNRS, 1991.

24. See for the US situation on this issue, Marx, G.T.: Undercover. Police Surveillance in America. Berkeley/Los Angeles/London: California Press, 1990.

25. Unterpertinger vs Australia, European Court of Human Rights, Series A, Vol. 110. Judgement of 24 November 1986, Application no. 9120/86; Kostovski vs Netherlands, European Court of Human Rights, Series A, Vol. 166. Judgement of 20 November 1989, Application no. 11454/85. 12 EHRR 434.

26. Brandstetter vs Austria 1991, European Court of Human Rights, Series A, Vol. 211. Judgement of 28 August 1991, Application nos. 11170/84, 12876/87 and 13468/87.

27. Lüdi vs Switzerland, European Court of Human Rights, Series A, No. 238, 1992. In this case the infringements of privacy (Art $8(1)$ ) by undercover agents were justified as being necessary in a free society (Art 8(2)).

28. HR 16-2-1982, NJ 1982,425. The Dutch Opium Act differentiates between intentional and non-intentional but culpable trafficking. The taxi-driver was sentenced for culpable trafficking. Most Western European countries have no punishment for culpable trafficking, except the Netherlands, Germany and Greece.

29. See Rüter, F.: Drugs and the Criminal Law in the Netherlands, o.c.; Trebach, Arnold S.: The loyal opposition to the societies. In: Van Dijk (Ed.), Criminal Law in Action. Arnhem: Gouda Quint, 1986.

30. Baanders, A.P.: De Hollandse Aanpak. Opvoedingscultuur, Druggebruik en het Nederlandse Overheidsbeleid. Assen: Van Gorcum, 1989.

31. Wiarda, J.: Mogelijkheden en beperkingen van de repressie-strategie. In: Groenhuijsen, M.S., Van Kalmthout, A.M. (Eds.), Nederlands Drugsbeleid in Westeuropees Perspectief, pp 49-59. Arnhem: Gouda Quint, 1989.

32. Böcker, B.F.N.: Rechter en rechtspraak in de drugsproblematiek. In: Groenhuijsen, M.S., Van Kalmthout, A.M. (Eds.), Nederlands Drugsbeleid in Westeuropees Perspectief, pp 89-96. Arnhem: Gouda Quint, 1989.

33. De Beaufort, L.A.E.J.: Strafrechtelijke marktbeheersing. In: Groenhuijsen, M.S., Van Kalmthout, A.M. (Eds.), Nederlands Drugsbeleid in Westeuropees Perspectief, pp 69-87. Arnhem: Gouda Quint, 1989.

34. Leijten, J.: NRC, December 1991. 


\title{
IV. DRUGS AS A PUBLIC HEALTH PROBLEM: ASSISTANCE AND TREATMENT
}

\author{
Leon Wever
}

In the Netherlands, present government policy on drug abuse is based on the view that drugs are primarily a problem of public health and welfare. In this Chapter, a short description is given of the policy developments with regard to assistance and treatment of drug users in the last decade. Particular attention is given to the results of two policy evaluations, followed by a discussion of recent trends in drug policy. The final section speculates on the future direction of Dutch drug policy.

\section{Background of a social drug policy, the 1970s}

When heroin entered the Netherlands in the early 1970s, most policy makers felt very uncomfortable with the idea that they had to rely on law enforcement in order to reduce drug supply and demand. These uneasy feelings may be explained by several distinct features of Dutch society in the 1970s. First of all, the early seventies were characterized by movements to decriminalize a variety of behaviors, which were considered private and expressive of a personal lifestyle. In particular, many legal provisions regulating sexual behavior were abolished. This resulted in a search for alternative ways of controlling social problems. At the same time, the proliferation of heroin use became especially noticeable among groups of immigrants from former Dutch overseas colonies - immigrants who were experiencing all kinds of social problems in a period of fast growing unemployment. Both developments prevented the drugs issue from being conceived as a single, isolated phenomenon; rather, drugs were viewed against the backdrop of adjustment problems of new immigrants and the general decriminalization movement.

Starting in the mid-seventies, the larger cities were very much involved in the process of urban renewal of deteriorated areas, where the problems of drug use and drug dealing were concentrated. Despite diverse attempts to solve the problems of the modern big cities by means of urban renewal and welfare programs, the drug trade soon became an inevitable element of urban problem areas. In addition to the socio-medical realities of addiction to illegal drugs, many people became economically dependent on the drugs trade in Dutch cities. 
During the seventies, one conclusion became crystal clear to academics, law enforcement personnel and social service professionals: the criminal justice system was definitely not the appropriate institution for solving drug addiction problems, particularly in view of the fact that drug problems appeared to be closely intertwined with other social developments. This awareness resulted in a call for a welfare-oriented approach: preventive measures on the one hand, and providing assistance and treatment to drug users on the other.

An institutional framework for drug treatment was already in place: throughout the country, there were a variety of both inpatient and outpatient alcohol dependency clinics. Initially, these alcohol dependency clinics were seen as the most adequate facilities for the treatment of drug users as well. However, it soon became apparent that the nature of drug addiction - with all its social complications - made the traditional treatment approach - directed at total abstinence - unworkable for most drug users. This was the major reason for the development of so-called "client-centered" facilities. In the bigger cities in particular, grassroots organizations and "alternative" youth assistance institutions (such as "Release" and the "SDI", the "Amsterdam Foundation for Drug Information") provided assistance directed at the immediate needs of people in trouble, such as providing shelter, daycare services, and basic medical care. These organizations proved to be better able to reach drug addicts and to take care of them. Providing "care" for a large number of drug users was found to work better than trying to "cure" a small group into abstinence. Fierce debates on the philosophy underlying the assistance and treatment of hard drug users accompanied these social policy developments. The more informal, low threshold, peer-oriented care and assistance approach competed with the more traditional, medicotherapeutic approach. The latter soon lost ground to the former. Within a relatively short period of time the new, "alternative" approach of providing care and assistance to drug users was officially accepted and incorporated into the national and municipal funding structures.

Dutch social drug policy has developed as part of a more general social and health policy - a policy which represents an important dimension of a much-encompassing social security system. Put simply, the Dutch state legally guarantees a reasonable income to anybody not capable of earning a living (due to unemployment or illness). Furthermore, virtually all income groups participate in a comprehensive and publicly controlled system of health care insurance. This means that, for the large majority, all medical needs are covered. In addition to the social security and 
health insurance system, the Netherlands has developed a tradition of fully subsidized social and welfare services, ranging from social work agencies, youth support services to community centers. The development of Dutch drug policy has to be understood against the tradition of largescale government involvement with social and health services. In addition, it should be noted that Dutch criminal justice policy has created the necessary "legal room" for the development of non-abstinence oriented drug treatment services.

\section{The development of drug treatment policies in the 1980s}

Present drug policy was fully developed and implemented in the 1980s. Three periods can be distinguished: 1 . a radical policy shift in the early $1980 \mathrm{~s} ; 2$. a time of policy evaluation in the mid-eighties; and finally, 3. the period dominated by AIDS and crime.

\subsection{A radical shift}

In the early eighties, downtown areas of the larger Dutch cities (i.e., Amsterdam, Rotterdam) became increasingly dominated by a highly visible drug population, creating feelings of uneasiness and annoyance among the public. It became apparent that many addicts were not reached by any public service. Furthermore, drug addiction had become increasingly a problem of the lower social-economic groups - groups that already were confronted with other social problems, such as unemployment, bad housing and crime. Ethnic minority groups, in particular, appeared to be hit hard by both drug addiction problems and unemployment, crime, and poor housing. Many drug treatment services were still only focusing on abstinence, without much regard for the social needs and manifest demands of the addicts.

It was during this time period that the urge for more direct and immediate ameliorative measures to deal with drug problems caused a major shift in national and local drug policies. The target of drug treatment was broadened. Increasingly, services were funded which focused on improvement of the physical and social situation of addicts, even when they maintained their drug use. These new services or new approaches within the existing facilities were mainly of an ambulatory, outpatient, or "low threshold" nature, for example, street corner work, open door centers or methadone maintenance facilities. Furthermore, they now explicitly attempted to address the problems as perceived by the clients: acute health problems, including withdrawal effects, money, housing, education and 
work. To phrase it in more general terms: this new approach focused on the reduction of social and medical risks related to the use of hard drugs, rather than on the termination of drug use. "Harm reduction" as the principal aim of drug policy was being practiced in the Netherlands before the concept was officially defined in the international drug policy context.

In addition, policies changed within the more traditionally oriented residential facilities. Cooperation with the outpatient services improved. Crisis- and detoxification centers were created, which also functioned as a connection between ambulatory and residential treatment. Treatment modalities - which typically had been of a long-term nature - became diversified; a variety of conceptual frameworks was introduced. Shortterm treatment and part-time treatment were established.

During the first half of the $1980 \mathrm{~s}$, this complex network of drug treatment and assistance facilities was established throughout most regions of the country. Any city with drug problems developed drug policies in which social assistance and diversified treatment played a dominant role.

\subsection{Two evaluation reports}

In the mid 1980 s, two large-scale evaluations of drug policy were conducted. The reports were written by groups of government officials with an administrative responsibility for drug policy. The first report, entitled the "1986 Review of Alcohol and Drug Policy" (Ministry of Finance 1986) attempts to evaluate drug treatment and assistance policies after the period of development and re orientation discussed above. The second report is entitled "Drug policy in motion, towards a normalisation of drug problems" (Interministerial Steering Group on Alcohol and Drug Policy 1985). In this document, the more fundamental problems and contradictions of drug policy are discussed and an effort is made to provide a rational theoretical foundation theory for future drug policy.

The 1986 Review was designed to provide cost-cutting arguments. Because of the lack of hard data and the political popularity of the drug demand-reduction approach, the government decided not to reduce funding. Instead, a program of evaluation research was started in order to draw conclusions about the effectiveness and efficiency of drug treatment and governmental treatment policy.

of much more importance for the development of drug policy in the Netherlands was "Drug policy in motion". This report was written by a coordinating and advisory body consisting of top government officials (Interministerial Steering Group on Alcohol and Drug Policy). To a large 
extent, the report was based on a sociological study of life histories of heroin addicts (Janssen and Swierstra 1982). The analysis of the heroin problem and the policy recommendations resulting from this research greatly influenced the ideas on social policy within the Interministerial Steering Group on Alcohol and Drug Policy. Its report contained a number of critical remarks about the effectiveness of drug policy in general. Furthermore, alternative policy options were discussed, ranging from legalization of drugs to compulsory treatment of drug addicts.

The report concluded that a coherent set of policy objectives and the required means for an overall drug policy were lacking. It was noted that policy objectives were often conflicting. It made a distinction between the primary problems which are caused by the use of drugs, and the secondary problems which are caused by the social context in which the substances are used. For instance, the primary problem of opiate use may be the mental and physical dependence it produces. In addition, this substance suppresses physical pain and emotions. These primary drug effects make users vulnerable for all sorts of physical and mental problems. However, there are additional (secondary) drug problems related to opiate use - a wide variety of undesirable phenomena, which do not exclusively bear upon users themselves. These secondary drug effects include a set of health problems caused by malnutrition and contaminated drugs and needles. There are also drug problems which are essentially unrelated to any property of the substance itself. These secondary effects include crime and prostitution, public expense for treatment and law enforcement and, not least, the infringement of civil liberties. All these additional, secondary individual and societal problems are inexorably linked to the world-wide prohibition of certain substances. The report argues that this has resulted in an international out-of-control black market, with high profits for the traffickers, and many risks to society.

The report concludes that most Dutch aid and treatment facilities deal with these secondary drug problems. This may be true even to the extent that one part of the drug policy is occupied with solving the problems caused by another part of the drug policy.

The report "Drug policy in motion" acknowledged the drug phenomenon as an inevitable, always present, aspect of modern society, with an established infrastructure of illegal and legal interest groups. It concluded that the existing traditional policy measures for reducing supply and demand were rather unsuccessful. Consequently, it considered the potential of two radical alternatives to existing practices: (1) legalization of illicit drugs, and (2) compulsory treatment.

The report argues that legalization of drugs would probably solve most 
of the secondary problems associated with drug use. Many drug problems directly related to the black market economy would disappear if the availability of drugs were less restricted. For obvious reasons, however, most notably the international conventions on drugs and the uncertain effects of legalization, the report deemed legalization out of the question.

Compulsory treatment was rejected for reasons of human rights and effectiveness. Because there is no guarantee that a particular treatment is successful, compulsory treatment would be reduced to a disguised form of mere detention. It is a fundamental Dutch legal principle that no-one can be forced into accepting treatment.

The report proposed a compromise between a policy leading to a war on drugs, and the other extreme of drug legalization. On the one hand, the war on drugs unwarrantedly denies the societal reality that drugs have become a normal, although undesirable, part of our culture. Legalization, on the other hand, tries to avoid the secondary problems as much as possible, yet fails to take into account political realities. The pragmatic policy proposed by the report is not aimed at total elimination of all drug problems, but rather at initiating a gradual process of controlled integration of the drug phenomenon in modern society.

Pragmatic drug policy calls for a process of "normalization" which involves managing the risks of psychotropic substance use in society, rather than getting involved in futile attempts at its complete elimination. This is not to deny that severe individual and family problems frequently result from hard drug use. Normalization requires, however, that "supposedly collective problems are demystified and socially redefined as primarily individual problems" (Engelsman 1989). At the end of such a process, the drug problem should be viewed as a "normal" problem, one of the several health and social problems a society faces and tries to control. Moreover and importantly, criminalization of the consumer is considered a harmful way of discouraging the use of hard drugs. Consequently, the normalization process requires de-stigmatization of drug users. "This does not mean that this phenomenon has been spirited away. But it has been put in another perspective in order to enable society to face the problems from a realistic point of view, unobscured by moralistic coloring" (Engelsman 1989).

The fact that pragmatic drug policy relies on factual and realistic means and steers away from a dramatized and over-emotional approach is clearly reflected in the Dutch prevention policy. The drugs issue is not addressed as an isolated issue by fright-invoking means. Instead, this subject is mainly discussed in school programs, where it is part of an integrated approach aimed at the promotion of healthy lifestyles. The 
main issue is not the radical abstention of illegal substances, but learning to cope with risk-involving behavior (including alcohol and tobacco use), and learning how to be responsible for one's behavior and choices.

This "normalization approach" regarding drug problems as proposed in the report "Drug policy in motion" was adopted as the formal foundation of drug policy by the Government in 1985 .

\subsection{Crime and AIDS}

In the mid-1980s, two new themes began to emerge in drug policy: crime and AIDS. Crime was on the increase. Drug-related crime, such as shoplifting and burglary by addicts who needed money to support their habit, appeared to continue, despite the readily available treatment and assistance facilities in the cities. Consequently, although, in theory at least, drug policy was to minimize the role of law enforcement in the lives of drug users, in practice many addicts still were confronted with the criminal justice system. It should be noted that Dutch drug users did not enter the criminal justice system because of illegal drug use or possession, but because of (drug-related) property offenses.

The crime problems in the cities and the drug problems in the prisons led to the adoption of a policy by which drug treatment and assistance became more oriented towards the needs of law enforcement. New policy measures inside and outside the prison were implemented, such as treatment as part of a conditional sentence, or a pre-treatment phase in detention in order to be released earlier.

The different policy adjustments had - again - one thing in common: the diversion from punishment to treatment, the voluntary character of treatment (it is the addict's decision to turn to treatment or not; the alternative is imprisonment just as for anybody else who has committed a serious crime), the use of existing legal instruments (e.g., conditional sentencing), and the use of all available treatment and assistance modalities, outpatient and inpatient.

The easy accessibility of the (voluntary) treatment and assistance system - more than $70 \%$ of addicts are estimated to be in contact with this system - proved to be of vital importance when AIDS began to emerge as a problem among drug users. It is a well-known fact that the lifestyle of many drug users, where needle sharing and unprotected sex with different partners are common phenomena, puts this group at a high risk for the spread of the HIV virus. When confronted with this new crisis in public health, existing drug policy was adjusted with "risk reduction" as its primary aim; an AIDS policy with realistic and feasible preventive 
targets was deemed essential for any pragmatic social policy.

The main target of the drug-related AIDS policy is to limit the spread of the HIV virus by attempted modification of risky behavior. This mainly implies safe sex and safe drug use, both of which may be achieved by reasonable changes of lifestyle. It is unlikely that reduction (let alone termination) of unwanted behavior can easily be achieved; therefore, a reasonable alternative is to teach safer techniques of involvement in the (still risky) behavior (drug use, sex). Thus, if drug use cannot be stopped - and we all know the limitations of intervention in this regard - using drugs in safer (non-intravenous) ways should be encouraged. And when this is not feasible - as practice sometimes shows - encouraging safe injection may be the most effective method. Health education for drug users is therefore being accompanied by the availability of sterile needles and syringes, as well as condoms.

Due to the fact that drug users form a well-defined high-risk group, efforts can be directly aimed at reaching these groups. This necessitates a large variety of drug treatment and assistance services which are easily accessible, an out-reaching approach of these services (street work, fieldwork in hospitals and jails, low-threshold "open-door-centers") and realistic, pragmatic intervention goals (i.e., not primarily directed at kicking the habit but at risk reduction). In the Netherlands, ambulatory drug treatment and assistance services, such as the Consultation Bureaus for Alcohol and Drugs and the Municipal Health Services (see section 3) fulfill a central role in AIDS prevention. It is not difficult to see why. They form a dense network throughout the country (in 60 cities, more than 100 outpatient services); they have already established contact with most of the drug-addicted population, and they are experts in influencing the behavior of drug addicts.

Although the majority of drug addicts were (and are) in more or less regular contact with drug treatment institutions, there remained a sizeable, more elusive group of intravenous drug users. Therefore, a need was felt to explore other ways of getting the health message across. Initial attempts were made to delegate the promotion of risk-preventive measures to the organized consumer groups of drug users, the so-called “junkie-unjons". In 1987 junkie-unions existed in 31 cities. Unfortunately, it soon became apparent that most of these groups were too weakly organized, and too institutionally isolated to be able effectively to tackle the job of AIDS prevention among the drug addicts. Subsequently, innovative health education and behavior modification measures were integrated within the traditional treatment and assistance facilities. A quick start of AIDS prevention among drug users was facilitated 
by the prompt and ready cooperation of the treatment and assistance services involved. Moreover, these agencies were willing to take unorthodox measures, such as the distribution of clean needles, or providing injectable methadone. They also accepted the idea of adapting their drug treatment efforts towards the aim of AIDS prevention.

The cities of Amsterdam and Rotterdam had already had some experience with the dispensing of sterile needles because of earlier efforts to prevent the spread of hepatitis among drug users. The needles were sold to drug users by the junkie-unions. In many cities, needles can easily be obtained from pharmacists, but in other places pharmacists are reluctant to accept drug users as clients. That is why, in Amsterdam, the first needle exchange program was set up by the junkie-union. A few years later, the project was adopted and extended by the Drug Abuse Treatment Department of the Municipal Health Service. Several other treatment and assistance services also started to include free needle exchange programs, sometimes within the context of methadone maintenance programs. At the present time, some police departments even provide needle exchange facilities for arrested addicts.

The national federation of drug treatment services (followed by the Netherlands Institute on Alcohol and Drugs) started an AIDS prevention program for all Dutch treatment services, financially supported by the Ministry of Health. This program has established a national network of AIDS prevention officers within the drug treatment facilities, in order to communicate new developments and to coordinate preventive actions.

In retrospect, three conditions - a network, consensus on preventive measures, and cooperation - have been essential in the successful implementation of an extensive and far-reaching national AIDS prevention program for drug users. Needle-exchange programs appear to lead to safer injection practices. Feared negative side-effects, such as increased use of needles because of increased availability, have not occurred (Hartgers et al. 1989). On the contrary, only $25-30 \%$ of Dutch heroin addicts use drugs intravenously. The percentage of intravenous drug using AIDS patients among the total group of AIDS patients is relatively low (Netherlands: 9\%; all European countries: 36\%; USA: 28\%; WHO 1992).

\section{Drug treatment services}

Because of the emphasis on the reduction of risks of drug use in Dutch drug policy, most policy efforts have been directed towards the development of assistance and treatment services for addicted drug users. Treatment for alcohol or drug problems by these agencies is free. Four types 
of services can be distinguished: 1. out-patient Consultation Bureaus for Alcohol and Drugs (CADs); 2. municipal methadone programs; 3. social welfare services for drug users; and 4. residential treatment facilities. This section includes a brief description of the major organizational and operational characteristics of these institutions.

\subsection{The Consultation Bureaus for Alcohol and Drugs}

The Medical Consultation Bureaus for Alcohol and Drug Problems (CADs) are autonomous, non-governmental, but publicly funded institutions, the entire costs of which are borne directly by 23 municipalities and 19 probation boards. Seventy-five percent of these funds are provided by the Ministry of Welfare, Health and Cultural Affairs through these municipalities. The remainder is financed by the Ministry of Justice through the probation boards. The nationwide network of CADs comprises 16 main branches, 44 subsidiary branches and 45 consulting rooms. The total budget amounts to Dfl. 80 million* per year.

The CADs are (mental) health institutions specifically oriented towards addiction problems. The institutions operate on the principle that the care, treatment and assistance they provide should ignore the legal (or moral) status of the object of addiction. Although the CADs primarily provide non-residential mental health care, their services are strongly oriented towards social welfare, as the majority of their staff (1000 in all) are social workers. The objectives of individual CADs may vary somewhat from overcoming addiction through treatment to stabilizing the condition of addicts by supplying methadone on a "maintenance basis". A variety of methods is used, including psychotherapy, group therapy, material assistance, family therapy, counselling, and advising groups of parents.

An increasingly important area of the CADs' work consists of advising and training teachers and members of more general health and welfare services, such as general practitioners and youth workers. This part of the work aims at enhancing the competence of the more general agents in the field of public health and welfare as far as (drug)addiction problems are concerned. Most recently, the CADs also fulfill major preventive tasks in the field of AIDS control (needle exchange, information and education).

Operationally as well as organizationally, the CADs are linked, in part, to the judicial system. This is of special importance in the field of drug

* One US Dollar is Dfl. 1.80 
addiction. The CADs cooperate with the general probation services in a program of early assistance to arrestees. Drug-using arrestees are visited in the police cell within the first $\mathbf{4 8}$ hours of their arrest. Arrested heroin addicts are offered methadone and efforts are made to establish contacts which will lead to the acceptance of assistance and counselling during and after detention in penal institutions.

\subsection{Municipal methadone programs}

In several of the larger cities, municipal authorities have set up their own methadone programs, administered by the municipal health services. The Ministry of Health provides the municipal methadone programs with a budget of about seven million Dutch guilders annually.

Methadone may be supplied on a reduction basis (the dose is gradually reduced) or on a maintenance basis (a constant dose). Methadone is now supplied either by a CAD or the municipal health service in virtually all population centers with a drug problem. As with the CADs, the municipal health programs have a central role in the field of AIDS prevention. At the present time, methadone is being provided to 7000 addicts daily in approximately 60 municipalities. Roughly three quarters of the clients receive methadone in a maintenance scheme. This means that, on average, about $40 \%$ of the drug-addict population in the Netherlands is in daily contact with methadone treatment. It is further estimated that, on an annual basis, about $75 \%$ of the addict population has been in contact with treatment or assistance facilities for drug users.

\subsection{Social welfare services for drug users}

The social welfare projects for drug users are part of a wide range of social welfare services aiming especially at young people. Traditionally, these institutions target multiple-risk groups where addiction problems may occur together with unemployment, ethnic minority status and other indicators of marginality. These welfare projects are typically subsidized on a local level, where facilities may be optimally suited to meet the most urgent needs. Some 550 people are employed in these services. The services are intended to be easily accessible and to have the widest possible outreach. They concentrate on different types of aid, often for young problematic drug users. Typical social welfare drug-oriented programs are: open door centers for specific groups (such as street prostitutes or homeless people), street-corner work, ethnic or religious therapeutic communities, night centers for homeless addicts, and social re- 
habilitation projects for (former) addicts, including supervised housing, vocational and social aptitude training, assistance in adjusting to a lifestyle that includes regular work, and possibly aftercare following some form of treatment.

A number of services is targeted to specific groups on the basis of their religious affiliation or ethnic and cultural identity. Some of these work nation-wide. The Ministry of Welfare, Health and Cultural Affairs has a budget of approximately 55 million Dutch guilders for almost 90 projects in 45 municipalities. Roughly one half of the total sum spent on these kinds of assistance to addicts is allocated to the four major cities: Amsterdam, Rotterdam, The Hague and Utrecht. Approximately one third of the total budget is earmarked for projects for ethnic minorities from former Dutch overseas colonies (living both within and outside the four main cities). The focus on different minority groups more or less mirrors demographic and drug-epidemiologic developments within the Dutch society. Consequently, assistance to addicts of Surinamese origin (Latin America) has increased considerably, while it has decreased sharply where Moluccans are involved. Most recently, more social welfare programs for young drug users are being directed at (children of) migrants from Mediterranean countries, who are turning to drugs in increasing numbers.

\subsection{Residential facilities}

Residential facilities for the treatment of drug addicts and alcoholics are located throughout the Netherlands, providing a total of 1000 beds. These facilities exist either as independent clinics or therapeutic communities, or as special units in general (psychiatric) hospitals.

Two major types of treatment are available: (1) crisis intervention and detoxification (which may last between two days and three weeks); and (2) clinical treatment (lasting from three months to a year, aimed at overcoming addiction). These facilities cost about 100 million Dutch guilders per year and are funded from contributions made under the Exceptional Medical Expenses (Compensation) Act, which is part of the Dutch public health insurance system.

\section{Trends and perspectives}

During the last two decades, Dutch drug policy has more or less continuously adapted to the changing drug problem and to changing policy assessments. This process will undoubtedly continue. 
Developments in recent Dutch drug policy may be characterized by several trends. The first trend is the acceptance as a matter of fact that drug use and drug trafficking will be an ever-present and inevitable aspect of modern society and, consequently, the understanding that largescale attempts at the "war on drugs" will be futile. A policy of zero tolerance may be seen by some people as morally just; however, for social policy purposes, it is deemed neither realistic nor effective. Therefore, a pragmatic policy has been developed aimed at reducing the personal and social risks of drug use, without necessarily expecting to terminate drug use at the individual or social level.

The second trend may be called a built-in flexible response of Dutch social drug policy which allows for adaptations to the changing needs of society. The specific problems of ethnic minorities, the growth of crime and the threat of AIDS are examples of these changes, requiring a reevaluation of aims and instruments in social drug policy.

Expansion is the third trend. The budget for drug abuse treatment and prevention, contrary to that for many other welfare and health services, has increased constantly.

The fourth trend is integration and rationalization. At the present time, a rather strong consensus has emerged on the objectives and means of drug treatment and assistance. Normalization, resocialization, risk reduction and prevention are the key concepts within this broad consensus of social drug policy.

The fifth trend is a re-appraisal of the role of the criminal justice system. If drug users are approached as normal citizens with rights and duties, they should be held accountable for their behavior just as anyone else. Addiction is no excuse for undesirable social behavior. At the same time, re-appraising the role of the criminal justice system implies acknowledging its usefulness in facilitating the achievement of treatment goals, for example, by conditional sentencing or in-detention preparation of treatment.

Finally, the sixth trend is decentralization. Since 1990, municipal authorities have had the primary responsibility for the development of ambulatory (outpatient) treatment policy. These authorities are most directly confronted with the practical social consequences of drug use. Consequently, they are considered to be the most suitable for making the practical policy choices.

Have these policy trends had an effect in terms of reducing the drug problem? There is some evidence available on the effects of drug policy.

As will be shown in Chapter 6, the use of illicit drugs (cannabis, heroin) has stabilized since the early 1980 s, as has the number of drug- 
related deaths. The average age of drug addicts is rising, as is the age of first use of heroin. The number of young drug addicts is decreasing. There is no indication whatsoever that the use of cocaine has increased rapidly or that non-deviant cocaine use presents severe addiction problems for a substantial number of people (Cohen 1989).

A growing number of drug addicts is in contact with drug treatment facilities. Both methadone maintenance and withdrawal treatment have become more popular. Currently, $75 \%$ of all heroin addicts are involved in some way with methadone programs. Ten years ago this percentage was closer to forty. The demand for residential withdrawal therapy has also doubled in the last ten years (Driessen 1990; Buning 1990). The needle-exchange programs appear to lead to safer injection practices.

These trends indicate that it is possible to manage and contain drug problems with an extensive policy aimed at drug demand and harm reduction, and a reduced enforcement of the law against consumers of drugs. However, there are also some trends which give a more negative picture. For instance, there is a small but growing group of "revolvingdoor" patients with a long addiction career and often psychiatric problems. Poly-drug use has become more prevalent, which makes drug abuse treatment more difficult (e.g., there is no substitution therapy available for cocaine addiction or heavy use of tranquilizers). Drug use among groups in a relatively disadvantaged social and economic position, particularly ethnic minorities, remains the most resilient problem. Despite the relatively favorable figures on the relation between intravenous drug use and HIV infection in the Netherlands, the spread of HIV among and from the drug-using population is still a threatening prospect.

What has the present decade in store? Undoubtedly AIDS will remain the most important social and health concern in connection with drug use.

AIDS undoubtedly constitutes a major social risk. AIDS and addiction give a double stigma, decrease the opportunities for resocialization and for leading a normalized life, and increase marginalization. Preventing this from happening will be an increasingly important challenge for drug treatment and assisting facilities. There is no use trying to treat a group for drug abuse only, while ignoring the fact that this group (and others) are taking deadly risks, are going to die or be expelled by society.

As far as the other trends described above are concerned, they will most probably persist in the foreseeable future, except perhaps for the expansion of services. The growing group of hard-core, psychiatric addicts will have to lead to an adjustment of treatment policy in terms of 
cooperation with psychiatric facilities.

The socio-economic position of several marginal groups in larger Dutch cities calls for increasing efforts to improve the level of education and employment. This is as important for social policy in general, as it is for social drug policy. Without improving these social conditions, attempts to make people stop using illicit drugs will be doomed to failure.

Current political forces within Dutch society strongly favor the present social drug policy of "normalization". In fact, the need to focus drug policies on harm reduction is no longer a topic of political debate. This large-scale political support of present drug policy may be threatened, however, by the increasing internationalization of drug policy.

The official United Nations drug policy strategy is based on both supply and demand reduction. In international political conferences and within international organizations, a growing number of resolutions are calling on national governments to develop demand reduction programs (Wever 1992). Since drug problems and the possibility to decrease demand for drugs are heavily influenced by local or national social and cultural factors, it is very important that the responsibility for this part of the drug policy lies primarily with the national states and local communities.

The international level is traditionally ill suited for developing demand reduction programs. The international drug policy strategy, as formalized in international conventions, almost completely focuses on the control of international trafficking of illicit drugs. The international institutional framework has the same built-in limitations. The few international organizations interested in demand reduction, such as the World Health Organization or the Council of Europe (Pompidou Group), have neither the political power nor the funds to compete with supply reduction as the most obvious and dominant part of international drug policy.

This situation may present two problems for national drug policy: one of a legal, the other of a financial nature. The legal problem might be that increasing efforts to reduce the supply of drugs by means of law enforcement and international cooperation reduce the freedom of individual states (i.e., the Netherlands) to continue their own pragmatic and non-moralistic drug policy. An example of this trend may be seen within the European Community, where the development of a common drug policy currently is a focal issue, with clear implications for the freedom of involved individual countries.

The financial problem may be a result of the attention that international drug policy is presently receiving from government leaders. The 
implementation of internationally agreed policy costs money. It is very well possible that public money will be allocated to those items of government policy that gain most political weight. In the case of drug policy, this may very well be the international cooperation in matters of law enforcement. This could mean that funds for law enforcement will be allocated at the expense of funds for social drug policy.

In the Netherlands, drug abuse is still seen mainly as a public health and welfare problem. But we have to accept the fact that this perspective is vulnerable in an international political debate where the drug phenomenon is seen as an object of warfare. History has shown that welfare and warfare do not get a long very well. The Dutch experience also shows that a social drug policy, directed at demand and risk reduction, is capable of containing and even diminishing the problems connected with drug use.

\section{Acknowledgment}

The author wishes to acknowledge the help of Ton Cramer (Ministry of Welfare, Health and Cultural Affairs) in checking some of the figures in this Chapter.

\section{References}

Buning, E.C.: De GG\&GD en het Drugprobleem in Cijfers, Deel IV. Amsterdam: GG\&GD, 1990

Cohen, P.D.A.: Cocaine Use in Amsterdam in Non-Deviant Subcultures. Amsterdam: University of Amsterdam, Institute of Social Geography, 1989

Driessen, F.M.H.M.: Methadonverstrekking in Nederland. Rijswijk: Ministerie van Welzijn, Volksgezondheid en Cultuur, 1991

Engelsman, E.L.: Dutch policy on the management of drug related problems. Br. J. Addiction 84:211-218, 1989

Hartgers, C., Buning, E.C., Van Santen, G.W., Verster, A., Coutinho, R.A.: The impact of the needle and syringe-exchange programme in Amsterdam on injecting risk behavior. AIDS 3:571-576, 1989

Interministerial Steering Group on Alcohol and Drug Policy: Drug Policy in Motion, towards a Normalisation of Drug Problems. Rijswijk: Ministry of Welfare, Health and Cultural Affairs, 1985

Janssen, O.J.A., Swierstra, K.: Heroïnegebruikers in Nederland, een Typologie van Levensstijlen. Groningen: Criminologisch Instituut Rijksuniversiteit, 1992

Ministry of Finance: 1986 Review of Alcohol and Drug Policy. The Hague, 1986

Wever, L.J.S.: Drug policy changes in Europe and the USA; alternatives to international warfare. Int. J. Drug Policy 3/4: 1992 


\title{
V. DUTCH PRISON DRUG POLICY: TOWARDS AN INTERMEDIATE CONNECTION
}

\author{
L.H. Erkelens and V.C.M. van Alem
}

\section{Introduction}

It is a well-known fact that Dutch drug policy has several unique features, setting it apart internationally. Although the Netherlands has a different way of handling drug problems, there are some problems Holland shares with other countries. One major problem common to virtually all Western countries is the pervasive influence of drugs in the sphere of criminal justice, especially in prison.

It was only recently that an explicit "penitentiary drug policy" developed (Van Alem et al. 1989). For a number of years the focus of drug policy excluded prisons. The issue of drugs and the correctional system scarcely got the attention of policy makers, neither from the field of public health nor from the penal law field.

However, by the end of the seventies a critical stage was reached; drug problems in prison were perceived as increasingly detrimental to both the addicted offenders, the prison climate as a whole, and to the goals of imprisonment. Currently (1991), about 50\% of the population is classified as addicted to hard drugs (mainly heroine, but also cocaine and amphetamines).

This chapter is concerned with the development and state-of-the-art of Dutch correctional drug policy. This policy has developed within the changing perspectives of general criminal justice policy and the general drugs (and crime) problem in Dutch society. Consequently, we will first take up the issue of recent developments in criminal justice policy and look at the corresponding changes within the Dutch penitentiary system. Next, we will elaborate on penitentiary drug policy and its implementation.

\section{Developments in Dutch criminal justice policy}

During the late 1960 s and 1970 s, the socializing and integrative elements (the so-called "denominational allegiances") in Dutch society progressively weakened (Van Dijk 1985; Downes 1988). These factors, in 
conjunction with demographic factors (i.e., mainly the post war "baby boom") and the emergence of long-term unemployment among segments of the younger generation, contributed to a change in criminality and criminal justice in Holland. There was a gradual, but consistent increase in the crime rate: the number of offenses reported to the police rose from 1,100 per 100,000 in 1950 to 7,100 per 100,000 in 1985 . (By the end of the 1980 s, crime rates started to level off.) Between 1950 and 1980, the crime rate increased by more than $700 \%$; the number of crimes solved by arrest declined from $50 \%$ in the 1950 s to below $20 \%$ in the 1980 s (Buikhuisen 1989).

These factors contributed to a gradual change in opinions about crime, criminals, and criminal justice policy. Until well into the 1970 s, criminality was primarily viewed as a problem of social deprivation; or alternatively, inspired by the "labeling theory", offenders were seen as the products of repressive means of social control (Buikhuisen 1989; Van Dijk 1985). Not only were these views shared by most criminologists, they were also quite strongly represented in the discussion of politicians and administrators dealing with criminal justice policy. The dramatic rise in criminality and criminal victimization transformed political (and public) opinion: there was a marked decrease in the general level of tolerance for crime in Dutch society.

Thus, the early 1980s saw the dawn of a new era in Dutch criminal justice policy. Part of the "toughening" of attitudes should be understood as a recognition of the (negative) side effects of earlier, more lenient policies. This resulted in a different official (i.e., governmental) perspective on crime, sentencing policy and judicial organization.

With regard to sentencing policy, for example, the number of prisoners with a sentence of more than one year increased markedly; in the period 1986 till 1992 by $44 \%$ (Vegter 1993). On the other hand, so-called back and front door options for diversion out of the prison system were offered to relieve some of the pressure. Moreover, a more prevention-oriented approach was implemented in criminal justice policy. An example are the measures directed at decreasing the rate of vandalism, for instance by means of techno-prevention or increasing the level of social control in some vulnerable areas. The "tougher" attitudes soon had consequences for the Dutch penal system. A government report "Society and Crime" (1985) was presented as a comprehensive policy plan to improve the maintenance and enforcement of law and order. The report suggested that drug-related crime was one of the main contributing factors to the sharp increase of petty criminality. In this context, more or less coercive (ranging from compulsive treatment to exerting some pressure) forms of treat- 
ment of drug addicts within the criminal justice system were mentioned as a policy option.

\section{Dutch prison policy}

The main foundations of the current Dutch prison system were laid after World War II. New legislation, embodied in the Prison Act of 1951 and the Prison Statute of 1953, gave rise to a differentiated prison system. Different kinds of prisons (from open to closed) were established, where offenders could be placed according to length of sentence, personality, type of offense and potential for rehabilitation.

The principle of rehabilitation is incorporated in Article 26 of the Prison Act. This Article states as the system's primary goal the orderly and safe execution of punishment, and preparing the inmate's return to society as its secondary goal. The concept of rehabilitation as such has changed over time. Until the end of the 1950s, rehabilitation was viewed mainly as a personal affair. In those days, the concept of rehabilitation had a strong moral dimension, dating back to notions derived from 19th century prison ideology. This ideology stated that incarceration was meant to bring on new moral insights among inmates. Inmates were expected to reflect upon their crimes and wrongdoings. To that end every prisoner was locked up alone, in one cell. There was virtually no contact possible between inmates in this so-called cellular system (Auburn system).

With some slight adjustments, this cellular system persisted until the early 1950s. However, with the Prison Act of 1951 a new principle was introduced. The new approach recognized that prisoners were social beings. (This recognition had a lot to do with prison experiences of many Dutch people who had been incarcerated as members of the resistance movement during World War II.) Rehabilitation was no longer considered a purely personal affair of moral redemption, but instead was primarily understood as a social process: prisoners had to be resocialized. They should learn proper social norms and values by staying together in more or less homogeneous groups. Prison work was seen as an important tool for resocialization. Prior to the prison Act of 1951 prisoners worked alone, each in his own cell. With the new Act they started to work together in workshops, approximating normal work processes.

The resocialization mission of the prison system was believed to be equally valid for all prisoners, but its implementation was thought to require differentiated means. All prisoners were placed in more or less homogeneous group regimes where they could start learning the social norms they were thought to be missing. For reasons of security and 
safety, prison institutions were differentiated according to criteria like age, gender, length of sentence, and legal status of the detainee. Youthful offenders were separated from adults and men from women. The prison system was differentiated into two levels of freedom of movement. Within the highest security level, prisoners were only permitted to operate as groups in the course of structured activities such as prison work. Otherwise prisoners had to stay in their own cell. Within the second level of security conditions, inmates only had to stay in their cell during the night. Any other time they were free to socialize and move about the ward.

At the end of the 1970 s, one had become more sceptical about the potentially resocializing effects of group regimes within a differentiated penal system. The growing scepticism echoed the often cited conclusion that in the field of correctional rehabilitation "nothing works" (Lipton et al. 1975). This changing attitude was also influenced by the disappointing results of Dutch evaluation studies of different prison regimes (Van der Linden 1978).

Starting in the early 1980 s, the conventional prison ideology of resocialization for all inmates began to lose its importance. Replacing the lofty aim of rehabilitation, more elementary goals for the treatment of offenders were formulated: namely, the principle of a humane confinement, and the principle of minimizing possible negative side effects of imprisonment. Both principles were to apply to all inmates. They may be considered as the Dutch minimum standards for dealing with offenders. A third and more ambitious principle was added to the two previous ones: to offer inmates opportunities to work on their personal development and psychosocial problems. This third principle may be understood as an updated operationalization of the resocialization ethic included in Article 26 of the Prison Act. This desirable end result of incarceration is no longer expected to be produced under all circumstances, but is viewed more as the outcome of a detention process shaped, to a large degree, by the inmates' own choices and motivation. Resocialization is now viewed primarily as a matter of providing options and chances within the prison environment, where it is up to the inmates to chose whether they want to take advantage of these chances.

Related to the introduction of these principles, new modalities of imprisonment have emerged. For several categories of problematic inmates, such as drug addicts, drunken drivers, mentally ill inmates, and inmates representing high security risks, special wings have been established. These developments are consistent with the framework provided by the 1951 Prison Act. Over the years, the principle of one inmate per cell has 
been maintained. The function of the single prison cell was transformed, however, from an instrument for moral redemption into a requisite for warranting minimal privacy of inmates within the prison walls.

\section{Some quantitative features of the Dutch penal system}

The increase of the crime rate in conjunction with the call for stricter law enforcement and longer sentences resulted in a shortage of prison cells in the 1980s. A long-term plan to expand penal capacity was developed and prison space has been significantly expanded during the last decade (Ministerie van Justitie 1989).

Table 1 gives an overview of the current capacity of the different prisons.

Table 1. Number of cells of the Dutch prison systems on 1-7-1991

\begin{tabular}{lrr}
\hline & $N$ & $\%$ \\
\hline Detention centers (jails) & 4973 & 65.1 \\
Closed prisons & 1223 & 16.0 \\
(Half-) open prisons & 1099 & 14.4 \\
Prisons for females & 345 & 4.5 \\
Total & 7640 & 100.0 \\
Total number of institutions & 58 & \\
\hline
\end{tabular}

The detention centers (jails) are intended primarily for persons facing criminal charges, but they also house sentenced offenders serving short sentences or awaiting transfer to a prison. Prisons are reserved for convicted offenders. There is a wide differentiation in prisons and in strictness of regime. There are a number of maximum security prisons for long-term offenders and a number of half-open and open prisons. The latter two types help ease the transition from the prison community to free society. Only a small proportion (less than 100 cells) within this minimum security category is of the "open" kind, in which prisoners are permitted to find work in the outside world and live with their families during the weekends. There is also a special group of offenders who are not placed in remand centers after their trial and sentencing; instead they are sent home to wait for a directive to report to a particular institution at a certain day. Indeed, it is quite common that, due to lack of capacity in the remand centers, defendants who should be incarcerated are actually sent home (Brand-Koolen 1987).

Prison capacity on January 1, 1981 was 3,798 cells; in ten years' time the overall capacity more than doubled to 7,640 cells. Proportionally, the closed prisons show the largest increase in capacity. The main cause of 
this development has been the increase in the average sentence length, which almost doubled from 3.2 months in 1982 to 5.7 months in 1989 . In 1990 , the incarceration rate (i.e., the number of people incarcerated per 100,000 inhabitants), was 48 - still one of the lowest in Europe. The mean incarceration rate in 1988 for 23 European countries was 62 per 100,000 (Van der Goorbergh 1990). During the past few years this number has gradually risen; at this moment the Dutch rate is about 50 per 100,000 .

In 1991 , about $40 \%$ of the detained population was in the pre-trial phase, $3.6 \%$ of the population was female and about $15 \%$ of the prison population was younger than 23 years of age; foreign prisoners made up about one-fifth of the total prison population.

The nature of the detained population has changed quite dramatically over the last decade or so. Perhaps one of the most prominent qualitative changes in the correctional institution in Holland has been the introduction of the drug-addicted offender. The drug-using inmate population has shown a steady growth since the mid-1970s; this has had an enormous influence on penal treatment policy. The remainder of this chapter describes the unique features of Dutch correctional drug policy, formulated in 1983 .

\section{The rise of penal drug problems}

"...one of the main unintentional effects of the use of criminal law to combat drugs has been the considerable growth of drug-abusers and drugrelated problems (smuggling, dealing, use) within .... the Dutch penitentiary system" (Rüter 1986).

We wholeheartedly agree with this conclusion. In $1980,23 \%$ of the prison population was estimated to be drug users; in 1982 this estimate had increased to 25\%-30\%; the most recent figure for 1991 is approximately 50\% (Jaarverslag 1992). This $50 \%$ figure has to be used with caution: remand centers, half-open prisons and closed prisons show markedly different rates (sometimes as high as $60 \%$ or $75 \%$ ). Because of the fact that registration is based on self-reports or/and needle mark inspection by correctional medical personnel, these figures probably underestimate the extent of drug use.

The increase in drug problems in penal institutions also results from the rising numbers of detained narcotic drug traffickers, who contribute heavily to the lengthening of the average time of imprisonment. About $25 \%$ of all inmates in Dutch prisons are sentenced for offenses against 
the Opium Act. The average length of prison sentences of drug traffickers rose steadily from almost seven months in 1982 to over 11 months in 1989.

The categories of addicted inmates and incarcerated Opium Act offenders (drug traffickers and dealers) are, of course, not mutually exclusive. Research has shown considerable overlap of more than $35 \%$ between the two categories (Rook 1982).

Furthermore, there is empirical evidence that not all drug addicts in prison are equally inclined to smuggle drugs into the prison. Perhaps it is not surprising that prisoners who are addicted to drugs and sentenced for both an offense against the Opium Act and for another crime (e.g., some property crime), are most inclined to continue drug dealing within the prison walls. It are these petty, opportunistic traffickers who have become addicted to their own stuff and who have subsequently committed property crimes who are most likely to smuggle drugs into prison.

The large influx of addicted inmates confronted the prison system with a range of new problems for which it was quite unprepared. These problems had to do with drug use, as well as drug smuggling and dealing, and the social tensions among inmates and between inmates and correctional personnel created by these illicit practices. In addition to these internal order and control problems, many new problems of a medical and psycho-social nature emerged for which prison personnel felt totally unprepared. The next section describes the way these problems have been dealt with by the Dutch correctional system.

\section{Main tenets of Dutch penitentiary drug policy}

Penitentiary drug policy may be viewed as a continuous learning process, partly the result of deliberate planning, partly shaped by trial and error. Since the early 1970s, Dutch policy makers have taken advantage of a variety of tools to obtain knowledge and insight into the problems of drugs in prison. The main elements in this process have been: practical experience of people working in the penal institutions; performing and evaluating experiments; specific training programs for prison personnel; and organizing seminars and task forces on specific aspects of correctional drug problems.

The direction of this developmental process may be described in terms of distinct policy stages. The first phase started about twenty years ago when, in 1972, the first hard drug addicts appeared in the prison system. During the first seven years (1972-1979), the whole process was strongly treatment-oriented. Drug problems in prison were first and foremost ap- 
proached from the addictive-disease perspective (Van Alem et al. 1989). Because addicted inmates were a new phenomenon, nobody knew how to deal with withdrawal problems, nor how to react to drug-seeking and drug-taking behavior. Prison doctors were bombarded with questions, from addicts as well as from prison staff. During that period the predominant view of addicts in prison was that of sick people whose crimes were the result of their illness. They were primarily viewed as patients, sick people who were actually out of place in prison.

This first socio-medically oriented stage of penal drug policy eventually led to two experiments in 1979, in remand centers in Amsterdam and Rotterdam. The goals of both experiments were: adequate detoxification, providing medical and psycho-social assistance for solving shortterm problems and, finally, transferring addicted inmates as quickly as possible to outside treatment programs. The crucial role of two teams of drug consultants of the Consultation Bureaus for Alcohol and Drugs (socalled CADs) was significant in both experiments. For the first time, personnel of a private and professional drug treatment organization was accepted and integrated into the prison system. One of the main outcomes of these first experiments was the institutionalization and further expansion of the role of external drug assistance professionals within the prison system.

Almost simultaneously with the start of the Rotterdam and Amsterdam experiments a fundamental change in penitentiary drug policy perspectives occurred. Establishing and maintaining control over drug trafficking and drug subcultures in penal institutions became a focal point of concern. A second phase of penitentiary drug policy started, during which the drug problem was primarily defined as a liability for order and security within the prison, specifically threatening relations among inmates and between personnel and inmates. Thus, in this phase (which also lasted some seven years, from 1980 to 1986), a control model prevailed. Typically, during this period a special prison was designated for prisoners who had been caught dealing drugs in prison.

Further, a special procedure was established to inform the Ministry of Justice as well as the public prosecutor about drugs confiscated in prison (including, if possible, the owners of the contraband). In this manner, criminal procedures against suspected inmates could be initiated. Finally, measures such as bodily searches and closer control of incoming mail and packages were either established or used more frequently. In theory at least, even defense attorneys, social workers and prison staff were no longer immune from scrutiny to prevent the importation of drugs into prison. 
Over time, the two dominant views - the socio-medical and the security control perspective - slowly merged into the third (and still prevailing) stage of penitentiary drug policy. The primarily control-oriented era came to an end in 1987, with the publication of a new policy plan called "Drug-Free Detention"*. The new plan was built on the idea that managing the drug problem and caring for the detained addicts should be compatible and mutually reinforcing.

\section{Drug-free detention}

The policy of drug-free detention is based on three goals:

1. To prevent as much as possible but not at any cost drug use and drug dealing within the prison walls.

2. To offer medical and psychological aid to inmates to overcome the direct effects of drug withdrawal.

3. To promote further assistance and treatment for those addicts who have shown to be genuinely motivated to do something about their addiction. Diversion to outside socio/medical institutions is a preferred means to reach this goal.

In other words, both drug control and providing primary care for addiction-related problems of prisoners are major tasks for the prison system. The policy assumes that more fundamental therapy, aiming at a "drug-free" life should be provided by the mental health system, but only when requested by the detainee.

These goals were formulated during the control-oriented period (in a policy document from the State Secretary of Justice to the Dutch Parliament in $1983^{\star \star}$ ), but it took some years before conditions were in place to implement the last two of these goals. Personnel had to get practical experience with working with addicted inmates and detained drug traffickers. Specific training and education programs had to be instituted as part of the general training of the prison staff. Finally, drug workers of the Consultation Bureaus for Alcohol and Drugs (CADs) had to be integrated into the prison system. In 1986, these CAD professionals obtained a structural position within the Dutch prison system. As part of a general

* Brief van de staatssecretaris van Justitie (Letter of the State Secretary of Justice), 7 april 1987. Over verslavingsproblematiek in de inrichtingen van het gevangeniswezen, TK 19861987, 18174 , nr. 9.

* Brief van de staatssecretaris van Justitie (Letter of the State Secretary of Justice), 29 november 1983. Over verslavingspolitiek in de inrichtingen van het gevangeniswezen, TK 1983-1984, 18174 , nr. 1. 
reorganization of the probation organizations in the Netherlands, it was decided that now $25 \%$ of the probation staff in the prisons had to be employed by the CADs.

The CAD organization has some characteristics which make it especially suitable for its role within prisons. Formally as well as professionally it combines the functions of a probation and a mental health organization. It is subsidized jointly by the Ministry of Health and by the Ministry of Justice. The "double" orientation of the CADs results, inevitably, in some tension but also has several distinct advantages. The organization is in a good position to mediate between the demands and needs of the criminal justice system and the mental health system. CAD workers are expected to provide new incentives to the further professionalization of drug care in prison.

The integration of the control and the care model was promoted by the 1987 introduction of two new mechanisms: the Drug-Free Unit (DFU), and urinalysis. Both measures were meant to support the goals of control and care in an integrated and mutually reinforcing way. The next sections will clarify this in some more detail.

\section{Urine testing}

A system of urine testing of incarcerated addicts was established in 1987 as part of the newly established Drug-Free Units (DFUs); participation in urinalysis within the DFU is contingent on a voluntary choice of the inmate to be detained in a DFU. One year later (in 1988), urine testing was introduced as a general investigative device for the presence of drugs anywhere in prison. One reason for the introduction of mandatory tests among the general prison population was simply to counteract the impression created by the designation of a DFU that drugs would be tolerated in other parts of prison. In addition, it was believed that levels of control inside and outside DFUs should not be too divergent, otherwise addicts would be less likely to opt for involvement in a DFU. Finally, it was feared that working conditions of prison personnel and probation workers might deteriorate in the absence of this form of control.

Mandatory urine tests outside the DFUs are not to be applied at random, but only in purposeful, functional and specified ways. As a general investigative device to detect drugs in prison, urinalysis may be imposed upon the inmate for several reasons. In the first place, urinalysis can be used as a method of gaining information on the prevalence of illegal drug use within prison. Secondly, urinalysis serves as an evaluation instrument 
for (violation of) furlough regulations. And, thirdly, these tests can produce the objective evidence in case somebody (for reasons of order and climate within the institution) is seriously suspected of drug use. In the first case, no disciplinary measures are attached to positive outcomes of urine tests; however, in the other two cases confirmation of drug use by urinalysis does call for sanctions.

No scientific evaluation of the effects of these mandatory urine tests has been done yet. Figures from the medical prison services in the first quarters of the years 1988 and 1989 indicate a sharp increase of urine testing, while the proportion of positive outcomes remains at a relatively low level. The data on urinalysis in Dutch jails and prisons are summarized in Table 2.

Table 2. Number of tests and percentage of positive outcomes of urinalyses for non-medical drug use in the first quarters of 1988 and 1989

\begin{tabular}{lrrrr}
\hline Substance & \multicolumn{2}{c}{1988} & & \multicolumn{2}{c}{1989} \\
\cline { 2 - 5 } & $N$ & $\%$ & \multicolumn{1}{c}{$N$} & $\%$ \\
\hline Opiates & 1812 & 2.1 & 2996 & 5.5 \\
Amphetamines & 341 & 0.0 & 947 & 0.3 \\
Cocaine & 1895 & 2.5 & 3574 & 3.3 \\
Barbiturates & 273 & 3.1 & 860 & 0.9 \\
Tranquilizers & 248 & 7.7 & 1230 & 3.7 \\
Methadone & 351 & 0.0 & 622 & 7.1 \\
THC (cannabis) & 626 & 11.6 & 1555 & 11.5 \\
\hline
\end{tabular}

The table shows that marihuana/hashish (THC) is the most frequently detected substance, and tranquilizers (benzodiazepines) to a lesser degree. The data further suggest that the numbers of positive outcomes have increased in this period.

\section{Drug-free units}

In 1985 the policy report "Drug-Free Detention" was published (Drugvrije Detentie 1985). One of its main proposals was the creation of "Drug-Free Units" within the prison system; the implementation of this policy was initiated by the secretary of Justice, in a letter to parliament in 1987 (TK, 1986-1987, 18 174, nr. 9). These DFUs were intended to provide protection and care to imprisoned drug addicts. DFUs were to protect addicts against drug dealers, provide assistance to help addicts overcome withdrawal problems and help them start preparations for a drug-free life. Institutions with high proportions of addicts among their 
inmate population were asked to design proposals for DFUs. Extra staff and extra resources for conducting urine tests were made available. A procedure for urinalysis was developed by the Ministry of Justice. Addicted inmates who apply to be placed in the DFU are required to submit to urinalysis before being accepted. There are no set standards with regard to the frequency of these tests and the possible consequences of a positive urine test. Additional probation officers of the CADs have been made available to DFUs to provide professional advice and support. Prison administrators were asked to develop specific treatment regimes aimed at the goals of protection and care. A system of urine tests, in addition to the provision of aid, assistance, and education on a daily basis were considered necessary elements of these regimes.

The decentralized approach (i.e., the request that prison administrators develop their own plans) proved to be rather successful. In a relatively short time the old "experiments" in the remand centers of Amsterdam and Rotterdam were reorganized and other DFUs were established. By the end of 1990 a total of thirteen DFUs were in operation: in jails (6), in half-open prisons (2), and in closed prisons (5). They offer a total of 333 places; their average capacity is about 25 places (minimum of 11 , maximum of 40). Assuming that there are about 2,400 addicts in the penitentiary population, we may conclude that this amounts to one drugfree cell for every seven addicts. Up till now, there are no DFUs for female addicts. The average stay in a unit differs and depends on the length of the sentence. In jails and in half-open prisons the stay generally does not exceed six months. In prisons the average is between 6 and 12 months (Boekhoudt en Verhagen 1990).

One of the new DFUs, with a capacity of 30 places, is located in a half-open prison. It serves as a follow-up for addicted prisoners who come from other prisons, to serve the last half year of their term. This unit forms part of a so-called "drug-free detention route". Its program is strongly oriented toward the post-detention phase. To that end, contacts have been developed with outside residential and ambulatory drug programs. A week-end leave policy provides the opportunity not only to go home but also to stay, for example, in an outside clinic to get an idea about what it means to enter a therapeutic community.

After five years of experience with the DFUs, what conclusions regarding effectiveness and feasibility may be drawn? From a correctional point of view, the question is important whether these units contribute to a reduction of drug use and drug trafficking in prison. The short- and long-term effects of a stay in a DFU on the drug addiction career are also of utmost importance. Other questions relate to the char- 
acteristics of participating inmates, the effect on prison personnel, and so on.

Although there is no conclusive scientific evidence as of yet, anecdotal information and qualitative interpretations of experiences with the DFUs indicate that the new facilities do offer new opportunities for addicted inmates; furthermore, the DFUs do appear to decrease the pressure of drug problems on the prison system in general. In these drug-free settings, correctional personnel have been trained to work together with the drug care professionals of the CADs. Opportunities are being created for several kinds of counseling, and for initiating contact with external drug clinics. There is more and more emphasis on the importance of follow-up treatment within the prison system (the so-called "drug-free detention route" we referred to earlier).

\section{Methadone treatment in prison}

A number of general practitioners (GPs) working in Dutch prisons prescribe methadone to addicted prisoners. This generally concerns only reduction programs, in which prescription of methadone is reduced to zero in the course of a few weeks. There are virtually no methadone maintenance programs inside prisons. Prison physicians operate as independent experts within the prison; they have the authority to decide whether or not methadone is supplied. No methadone is provided to prisoners in DFUs. A small recent survey gives some data on the number and kind of methadone programs in jails. Of the 30 remand centers, 24 provided methadone and six did not. All of the programs were short-term reduction programs with a maximum dose range between 30 and $50 \mathrm{mg}$. Most of the remand centers (20) had a 1- to 4-day reduction program with a 5-mg reduction per day (Kools 1992).

Many addicts are clients of community-based methadone programs when they begin their incarceration. This explains the tendency of the Dutch prison system to use detoxification by means of methadone reduction, instead of a "cold turkey" approach. Dutch medical jurisprudence has established that prison doctors are obliged to verify a prisoner's claim that he or she has been a client of an outside methadone program. After confirmation of prior enrollment in a methadone maintenance program, it is then up to the prison physician to decide whether or not to prescribe methadone.

A 1986 conference for Dutch prison physicians on the topic of methadone suggested consensus on several points. A system of effective supervision and management is considered essential to prevent abuse (i.e., to 
prevent the dealing of methadone in prison). Urine testing was proposed as an indispensable tool for monitoring illegal drug abuse. Conference participants unanimously rejected methadone maintenance for prisoners with sentences over six months. All agreed that no particular medical arguments (i.e. harmful detrimental effects of methadone) were available against overcoming physical dependence by means of a methadone reduction program; however, the attitudes on prescribing methadone varied markedly. Some prison doctors reasoned that the prescription of methadone is only necessary in some extreme cases to alleviate withdrawal symptoms. Others were convinced that it should be the addicts' own responsibility to take methadone or not. In this view, detoxification makes only sense if an addict is really motivated to become drug free. This implies that the addicts determine the moment they want to stop using methadone. However, all agreed that continuing illegal drug use would be sufficient reason to stop the prescription of methadone.

One leading Dutch (former) prison physician experimented with the "methadone on demand" approach. According to his experience, the large majority of addicted inmates stopped using methadone after approximately two months. This may be interpreted as positive support for the "own responsibility approach", at least within the coercive context of the prison. According to this prison physician (Roorda 1990a), two types of drug addicts tended to choose for methadone maintenance. One category may be described as the "extremely problematic" drug addicts, often characterized by co-morbid psychiatric disorders. The other category consists of young addicts who are still in their "honeymoon" phase. For the first category detoxification is (medically) not advisable. For the "honeymoon" type of addict a reduction program is seen as most appropriate. Both categories, however, only constitute a small segment of the detained addict population. The largest, most challenging group, according to Roorda (1990a), consists of addicts who, once in prison, are willing to detoxify but are afraid to make this decision because of anticipated withdrawal problems. They tend to prefer to start the detoxification process on a methadone maintenance basis. Roorda argues that it would be unwise to try to persuade these addicts to "go cold turkey", to move directly into abstinence. An "open" attitude of the prison doctor, which includes acceptance of the addict's possible relapse, is considered necessary for succeeding in the long run.

At this point, there exists no registration of the prescription of methadone in Dutch prisons and detention centers.

From the 1991 statistics provided by the chief medical officer of the correctional system it can be concluded that about one third $(3,131)$ of 
the drug users entering the prison system (total in 1991: 10,745) get some form of methadone treatment (Jaarverslag 1992). Clearly, lower doses of methadone are prescribed to detained drug addicts as compared to nondetained drug addicts, averaging respectively 20.1 and $41.3 \mathrm{mg}$ (GG \& GD 1990).

Up to now there has been no thorough discussion about methadone as an instrument for prison health policy among professionals and administrators in the correctional field. For some subgroups of the prison population - e.g., older addicts who have been using prescription methadone for a long time - methadone could be a viable option to keep them from "drug-seeking" behavior in prisons, to alleviate their symptoms, to stabilize their "pharmaceutical pattern" and thus to meet the objective of continuity of care. Obviously methadone could also prove to be an important health safeguard for IV users "at risk" of HIV infection because of their needle-sharing and/or risky sexual behavior.

\section{Recent developments}

Drug policy in Dutch prisons has gradually evolved towards an (attempted) balance between control and care measures. The gradual, incremental development of prison policy is, partly at least, a result of the decentralized nature of prison administration; prison staff has a fair amount of freedom to develop their own initiatives.

The care of addicts in prison (which expressly deliberately stops short of treatment to abstinence) is of limited use, however, when adequate connection with drug treatment outside prison is lacking; there must be some continuity between the prison experience and the outside world. One of the options to improve the connection between the prison and the community-based drug assistance system is the "article 47" clause; this provision allows addicted prisoners to be diverted to a treatment clinic outside prison after half of the sentence has been served. They can opt for completing the other half in a residential setting with an upper limit of half a year. If, after admission to the treatment center, they fail to comply with the conditions, they will have to return to prison. In 1989, 116 applications to "article 47" were made; 95 were granted. At present, this arrangement is considered the main tool for implementing the (third) goal of Dutch prison policy: providing real therapy for motivated addicts outside the prison system.

Analysis of article 47 transfers (Roorda 1990b) during the period 1982-1989 has shown that both the applications and the actual number enrolled in treatment have increased: in 1982, there were 38 transfers to 
outside treatment agencies, in 1989, there were 95 transfers. The mean number of days in treatment has remained fairly constant over the years, between 70 and 80 days. However, the percentage that drops out of treatment within two days after enrollment has gradually declined from $24 \%$ in 1982 to $16 \%$ in 1989 .

Another method to enhance the continuity between the prison and drug-related community services is the further implementation of "drugfree detention routes". The communication and relationships between the different DFUs have to be improved. For example, in the selection process where detainees from remand centers are sent to closed prisons and - if possible - from a closed prison to a half-open or open prison, an important (early) criterion is the addict's motivation to "kick the habit". It makes sense that the initial steps made in a DFU in the first phase of detention (i.e., in the remand center) should be followed by other ones, building on earlier decisions and experiences. In the final phase of the period of incarceration, prison programs must be available which offer opportunities for the social re-integration of the (former) addict. (In this context, we want to mention again the special half-open prison for drug addicts.)

In a recent government document, some guidelines for DFUs were proposed (Contourennota 1990). The following conclusions reflect the stateof-the-art philosophy of Dutch prison policy with regard to drug addicts:

1. DFUs in jails and half-open prisons serve a different function than DFUs in prisons. DFUs in prisons function as follow-up facilities for offenders transferred from jails. DFUs in jails are more general because of the heterogeneity of the population and the broad spectrum of (often acute) mental health problems.

2. The objectives of DFUs must be more clearly stated; the units should be open only for addicts who actively choose for participation in the program. This requires clear and unambiguous criteria for the required motivation.

3. Urine testing should remain as a protective tool, both for the addicts and the staff. However, the frequency of the urine tests should increase.

4. An additional forensic addiction clinic may be needed to complement the range of other available addiction treatment facilities.

These conclusions are still open to debate; however, the main message is clear. The Dutch want to give DFUs a fixed place within their prison system, define a clear target group, and place these DFUs in a broader spectrum of treatment alternatives both within and outside the prison sys- 
tem. Meanwhile, the focus on drug addiction problems within the prison population should not blind us to the fact that these problems are often part of a complex syndrome of socio-psychiatric disorders. A survey in one specific facility for juvenile offenders showed that about $80 \%$ of the inmates could be qualified as addicted to substances, while about $50 \%$ of those addicted to drugs had recent psychiatric problems (Bulten et al. 1992) This means that DFUs should not only be linked to the drug care and treatment systems, but also to general mental health institutions in the outside society. Up till now there is no such linkage.

\section{Back-door and front-door options}

In this chapter, we focus on the treatment of drug-addicted detainees and the measures directed at preparing them for the post-detention period. This policy is referred to as the "back-door option" for criminal drug addicts. By implication there must also be a "front-door option" offering an alternative way out of drug addiction. This alternative can be realized in the framework of community-based sanctions.

Within the Dutch criminal justice system, custodial sentences are officially considered as sanctions of last resort. If the social order has been severely disturbed or if victims of a crime need to be protected, incarceration is often viewed as unavoidable. Nevertheless, the harmful side effects of imprisonment, such as loss of occupation or the deterioration of social relationships - placing marginal people in even worse circumstances - should be minimized. The judge and the public prosecutor have different legal instruments at their disposal to apply sanctions other than imprisonment. In the pre-trial phase the public prosecutor may waive prosecution or put an end to remanded custody under certain specific conditions, depending on personal characteristics of the suspect. The prosecutor, for example, may require an offender who is a drug addict to have himself committed to a drug assistance or treatment program, either inpatient or outpatient.

Especially for juvenile delinquents there are various community-based sanctions available, but community service orders (CSOs) for adult offenders are also frequently applied. For example, in 1990 about 7,000 CSOs were issued against adults. Furthermore, for short custodial sentences, there is the option of so-called weekend enforcement. It should be emphasized that in the Netherlands community service orders are applied only as an alternative to imprisonment, that is, only when otherwise unconditional prison sentences (max. 6 months) would have been imposed. They constitute no sanctioning alternative in their own right. 
Therefore, a failure to comply with the terms of a CSO will almost inevitably result in the enforcement of the prison sentence the order was meant to replace.

Experience has shown that without special support drug addicts almost invariably fail to comply with the conditions of a CSO For that reason some special projects have been implemented to make diversion to treatment and assistance programs a more viable option for criminal drug addicts. Examples of such projects are the Drug-Related Crime Project in Rotterdam (see Chapter 10 in this book) and the Street Junk Project in Amsterdam. Both are fairly small projects, using a mix of work, training, and medical assistance, and they are developed in close cooperation between probation agencies and the office of the public prosecutor.

Front-door options certainly have distinct advantages, compared to back-door options; however, front-door options for criminal drug addicts in the Netherlands are only just beginning to develop.

\section{Conclusion}

The drug problem has had a pervasive influence on the Dutch correctional system in a quantitative as well as qualitative sense. There has been a tremendous increase in the available prison capacity the last ten years, mainly because of the increase in the average sentence length. The qualitative changes relate to the change in the composition of the incarcerated population and the increase of drug-related problems, such as smuggling, dealing, drug use and (mental) health problems. Especially because of these qualitative changes it has taken considerable time to find a right mix between drug treatment and assistance and custodially oriented measures.

It is only recently that a more balanced penal drug policy has been developed. This policy tries to merge care and control goals. It aims at creating a detention climate which makes it easier for the addict to get help; the policy intends to create a linkage with civil treatment and assistance modalities. At the same time a number of control measures have been implemented to ensure a safe execution of the sentence. One of the most important remaining tasks is to improve the organizational framework for special drug-free facilities. Importantly, the different DFUs in different penal institutions need to be transformed into a better integrated (sub-)system.

Current prison drug policy is consistent with the pragmatism typical for Dutch drug policy in general: one learns by doing, from experience, fully aware of the fact that striving for a drug-free environment at all 
costs is an unrealistic goal. An additional reflection of the pragmatic attitude is that DFUs are viewed as having an educational and motivating function, rather than a treatment function. A main concern remains the question if prisons are suitable places for treating drug-addicted offenders in the first place. That is why many strongly believe that the search for other, less restricting sentencing options and non-institutional options (e.g., CSOs) has to continue.

Prison drug policy is faced with a number of constraints. First, it develops as a by-product of drug policy in general. This implies that prison drug policy can never develop as an independent entity, detached from drug (treatment) policy in general. That is why so much emphasis is given to the development of the linkage function of prison drug care, both with community drug treatment and with community mental health treatment programs. Secondly, the goal of the orderly and safe execution of the sentence puts serious boundaries and restrictions on the treatment and care objective. Thirdly, the need for treatment is not limited only to drug addicted offenders; many other offenders have (mental) health or social problems in need of assistance.

Although important initiatives have been taken, Dutch prison drug policy is maturing only slowly. In a general sense, the drugs problem has forced the correctional system to re-think and to re-operationalize the ambiguously defined goals of incapacitation and rehabilitation. It is evident that penitentiary drug policy can only develop in a desirable and fruitful direction if penitentiary drug problems are seen as part of the total drug problem of society, not as a separate entity.

\section{References}

Boekhoudt, A. and Verhagen, J.J.L.M.: Drugsvrije afdelingen in penitentiaire inrichtingen. The Hague: Ministerie van Justitie, 1990

Buikhuisen, W.: Imprisonment in Holland: Some comments. International Journal of Offender Therapy and Comparative Criminology 33:154-158, 1989

Bulten, E., Van Limbeek, J., Wouters, L., Geerlings, P. and Van Tilburg, W.: Psychische Stoornissen in Detentie; een Onderzoek naar de Prevalentie van Psychische Stoornissen bij Gedetineerden van de Jeugdgevangenis Nieuw Vosseveld. The Hague: Ministerie van Justitie, 1992

Brand-Koolen, M.J.M.: The Dutch Penal System and its prisons: an introductory note. In: Brand-Koolen, M.J.M. (Ed.), Studies on the Dutch Prison System. Amsterdam: Kugler Publ, 1987

Contourennota: Drugsvrije Afdelingen in Penitentiaire Inrichtingen. Coördinatiegroep Drugsbeleid; Directie Delinquentenzorg en Jeugdinrichtingen. The Hague: Ministerie van Justitie, 1990

Downes, D.: Contrasts in Tolerance; Post-War Penal Policy in The Netherlands and England and Wales. Oxford: Oxford University Press, 1988 
Drugvrije Detentie. Rapport van de werkgroep Drugvrije Afdelingen. The Hague: Ministerie van Justitie, november 1985

Dwang en drang in de hulpverlening aan verslaafden. Tweede Kamer, 1987-1988, 20415 , nrs. 1-2, 1988

GG \& GD: Methadonverstrekking in Amsterdam in 1989. Jaaroverzicht van de Centrale Methadon Registratie. Amsterdam: Gemeentelijke Geneeskundige en Gezondheidsdiens Amsterdam, Stafbureau Epidemiologie en Documentatie, 1990

Jaarverslag 1991 van de Geneeskundig Inspecteur bij het Ministerie van Justitie. The Hague, 1992

Kools, J.P.: Methadonbeleid HvB's in schema ("Cold turkey in de bajes"). Mainline 2(4):1417,1992

LADIS (Landelijk Alcohol Drugs Informatie Systeem). Jaarverslag (1986). Utrecht: Nederlandse Vereniging voor CADs (NVC), 1987

Lipton, D., Martinson, R., Wilks J.: The effectiveness of correctional treatment, a survey of treatment evaluation studies. New York: Prager Publ, 1975

Ministerie van Justitie: Rapport Voorzieningenbeleid 1990-1994. Delinquentenzorg en Jeugdinrichtingen. The Hague, 1989

Rook, A.: Probleemgroepen in Inrichtingen voor Langgestraften; een Inventarisatie. The Hague: Ministerie van Justitie, Wetenschappelijk Onderzoeks- en Documentatie Centrum, 1982

Roorda, P.: Methadon in penitentiaire inrichtingen. In: Van de Wijngaart, G., Verbraeck, $\mathbf{H}$. (Eds.), Methadon in de Jaren Negentig (WGU-cahier 12). Utrecht: Rijksuniversiteit Utrecht, 1990a

Roorda, P.: Artikel 47 van de Gevangenismaatregel bij de Behandeling van Verslaafden; Verslag over 1988-1989. The Hague: Ministerie van Justitie, Directoraat Generaal Je ugdbescherming en Delinquentenzorg, 1990b

Rüter, F.: Drugs and the Criminal Law in the Netherlands. In: Van Dijk, J., Haffmans, C., Rüter, F., Schutte, J., Stolwijk, S. (Eds.), Criminal Law in Action; An Overview of Current Issues in Western Societies, pp 147-166. Arnhem: Gouda Quint, 1986

Van Alem, V.C.M., Erkelens, L.H., Schippers, G.M., Breteler, M.H.M. and Becking, J.M.: Verslavingsproblematiek in penitentiaire inrichtingen. Justitiële Verkenningen 15(2):39. 61,1989

Van Dijk, J.M.M.: Beleidsimplicaties van criminologische theorieën en implicaties van het beleid voor de theoretische criminologie. Tijdschrift voor Criminologie 27:320-345, 1985

Van der Goorbergh, J.: Persconferentie opening Huis van Bewaring Sittard, 16-02-1990, 1990

Van der Linden, B.: Regiem en Recidive. The Hague: Wetenschappelijk Onderzoeks- en Documentatie Centrum, Ministerie van Justitie, 1978

Vegter, P.C.: De toename van lange gevangenisstraffen: malaise voor het gevangeniswezen. Nederlands Juristen Blad 29 (26 augustus) 1993

Verhagen, J.J.L.M.: Veranderingen in de gedetineerdenpopulatie in de afgelopen tien jaar. Justitiële Verkenningen 15:7-16, 1989 
PART II

LIMITED PROBLEMS AND MODERATE MEASURES 


\title{
VI. THE DEVELOPMENT OF CONTEMPORARY DRUG PROBLEMS
}

\author{
Koert Swierstra
}

\section{Dutch drug problems $1970-1990$}

\subsection{Introduction}

Prior to the 1960s, drug use in Holland was limited to opium smoking by the Chinese community - a habit well known from the former Dutch colonial age in Indonesia and tolerated by the authorities provided the practice remained confined to the Chinese community - and the smoking of marihuana and hash within small subcultural circles in Amsterdam. During the 1960s, however, things were to change. First, the use of marihuana and hash became more common among young people in the whole country. And second, around 1965, the first young Dutch opium users presented themselves in the cities of Amsterdam and Rotterdam. In addition, Dutch youth discovered that amphetamines could be used for other than strictly medical applications. Although LSD played a modest part as well, the prelude of hard drug problems in the Netherlands was characterized by opium and amphetamines.

These early developments notwithstanding, it is fair to say that until the end of the 1960s, there were no genuine drug epidemics in Holland. This is reflected in the fact that the Dutch professional literature of that time only mentioned heroin as simply an opium derivate (methadone was still unknown at that time); American writings, on the other hand, already discussed these substances.

The use of hard drugs in Holland as a fairly significant social problem dates back to the beginning of the 1970s. It was the introduction of heroin in 1971/1972 which produced an explosive growth in the use of hard drugs in Holland. The Dutch development paralleled earlier experiences in the United States and later Britain, and occurred simultaneously with the introduction of heroin in (former) Western Germany. There is no question that the contemporary hard drug problems must be traced back to the introduction of heroin in Holland. During the 1970s, then, hard drug use spread fast, making it a structural social problem. The 1980s, however, were characterized by new trends and developments 
in the patterns and extent of drug use in Holland. Can we speak of specific Dutch drug use careers? Is there a uniquely Dutch history of drug problems? What is the role, if any, of drug policy in this? Is it possible to identify uniquely Dutch factors involved in recent developments? This Chapter attempts to address these questions by tracing the history of hard drug use and problems in the Netherlands over the last two decades.

\subsection{Epidemiology}

According to our best estimate, the number of opiate addicts in Holland had grown to approximately 25,000 by 1980 . Between 8,000 and 10,000 of these addicts were thought to live in Amsterdam, the capital of the Netherlands. (These figures are accepted by most drug researchers and policy makers as correct, although some have arrived at higher estimates.) However, estimates of developments during the last decade have systematically been lowered. Current national estimates range between a minimum of 15,000 and a maximum of 20,000 opiate addicts. Moreover, several sources indicate that the mean age of addicts - another measure of the seriousness of drug use - has been consistently rising. Recent studies in Amsterdam and Rotterdam arrived at an average age of 30 years. (This finding is consistent with observations in the much smaller city of Heerlen.) Amsterdam Municipal Health authorities reported that the mean age of their drug clients increased from 27 to 30, between 1981 and 1987. In the same period, the proportion of addicted clients under the age of 22 decreased from $14 \%$ to less than $5 \%$.

These figures strongly and consistently suggest that the number of opiate addicts in Holland indeed is declining. Although drug use in general appears to be decreasing, it is likely that drug use figures for specific (ethnic) subgroups such as Moroccan youth from North Africa will continue to rise. It is also important to realize that lower estimates of drug addiction have to be handled with caution. For instance, in the United States, lower estimates of opiate users (Des Jarlais and Uppal 1980:336; Inciardi 1986:71) fail to reflect a real diminishing of hard drug addiction in general. Among other things, the picture may be distorted by a temporary shift to other hard drugs.

\subsection{Drug use patterns: from heroin to methadone, pills, cocaine}

Opiate addiction (including prescription methadone) has formed the core of drug problems in the Netherlands since the introduction of heroin 
in the early 1970s. Currently, however, the dominant pattern for the opiate addict is to use various drugs, alcohol, and/or prescription drugs in addition to heroin and methadone. Similar to the situation in other countries, this poly-drug use is occasionally supplemented with new trendy substances such as XTC. Interestingly, popular American drugs such as crack and PCP have not taken firm root in the Netherlands.

Two important aspects of the current multiple drug use pattern are: the decreased significance of heroin and the increased significance of cocaine. The first development has already been illustrated for the situation in New York in the 1970s by Preble and Miller (1977). They showed how the predominant use of heroin was replaced by a pattern of multiple drug use of methadone, cheap wine, and pills. These substances are not only cheaper, but also easier to get; for the addict it takes less (income-generating) crime. This consumptive pattern better matches the way of life of the older addict, who gets more or less burnt out after years of a rough drug life. It is reasonable to argue that this is especially important for the Dutch situation, with its aging addict population. Indeed, studies among hard drug users over the last years consistently find multiple drug use the predominant pattern. Drug addicts now use less heroin and more pills and alcohol; for approximately two out of three, prescription methadone is the primary opiate drug. Heroin, the good old original, may be used more during the one weekend in the month when social security payments are paid.

The second process complements the first: cocaine has replaced heroin, at least to a certain degree. The popularity and myths of cocaine are well known, not the least in the United States. Cocaine makes you bigger, more self-assured, it keeps you sharp and part of the world; heroin, on the other hand, makes you lethargic and spaced-out. With coke, one can achieve, be a winner in social competition. As cultural symbols, the myths of opiates belonged to the 1970 s, those of cocaine to the 1980s. Today, if drug addicts have enough money, they use both substances together; if they lack the money, they prefer cocaine. Recent studies conducted in Rotterdam and Amsterdam mention cocaine use in nine out of every ten opiate addicts. Moreover, preference for cocaine is typical for recent hard drug incidence patterns (Intraval 1989:98; Korf 1987:71). Research among Rotterdam addicts indicates that most of the relative novices (who had used hard drugs for no more than two years), started with cocaine before getting involved with heroin use. Several studies suggest that drug addicts who use a lot of cocaine are more criminally active than addicts who use a lot of heroin. With the exception of Cohen (1989), the question of cocaine use outside the deviant world of 
multiple drug addicts has not been studied in the Netherlands. (A few studies are currently in progress.)

Before evaluating the developments of Dutch drug problems over the last 20 years, we will take a brief detour to look into the social make-up of the phenomenon of hard drug use.

\subsection{Hard drug careers: addicts and the drug world}

It is only normal that most (if not all) people occasionally seek distraction or pleasure in order to escape the daily routine, to solve conflicting demands, or whatever. For adults with close bonds to society, the institutional order and dominant culture provide various non-deviant ways of doing this: for example, through alcohol, use of medicine, gambling, and so on. For young people, on the other hand, who typically have fewer social bonds and less vested interests than their adult counterparts, it is more likely that their options will become deviant. Their environment often responds to this youthful deviance, thereby further reducing their options. One way of coping with the resulting problems is to get involved with drug-using peer groups. Hard drug use reinforces deviance.

In addition to a negative social response from the environment, the phenomenon of hard drug use is shaped by the criminal economy of the drug world, the relationship with deviant behavior among youth, and the addictive qualities of the substances. Habitual use of hard drugs is related to a specific way of life, a way of life which may become even more addictive than simple drug use. The notion of a social "addiction" to the drug way of life was introduced a long time ago by a number of American authors in the field. The tradition goes back at least to Becker (1963:53) and includes among others Lindesmith (1968:49), and Preble and Casey $(1969: 21)$. A related notion is the concept of the deviant career. This concept includes a socialization process into the drug world, different phases of drug use, a series of institutionalized contacts with mainstream society (e.g., police, courts, drug treatment and care programs), and an eventual termination of the career because of burn-out. For drug addicts with a long history of addiction, the police record begins to take on the same social function as a curriculum vitae in conventional society: as some type of calling card (Abrams 1982:296). (See also Waldorf 1973; Maddux and Desmond 1981; Biernacki 1986.)

The commitment to the drug way of life should be viewed in relationship to the degree of integration in conventional society. The addict to illegal drugs lives in both worlds, taking reference points from both the deviant world of drugs and regular society. The stronger the bonds to 
conventional society, the greater the sociological distance towards an integrated position within the drug world. And, as we will see later, the balance between the two worlds is not the same in the different stages of the drug career.

\section{Incidence in the $1970 \mathrm{~s}$}

\subsection{The impact of subcultural backgrounds}

The first large-scale generation of heroin addicts in the Netherlands was described, among others, by Janssen and Swierstra (1982). We analyzed how some specific youth subcultures contributed to the spread of heroin use in Holland, and how individual careers progressed from the subcultural phase of initiation into hard drug use into a fully fledged junkie way of life. In this respect, a new opportunity structure of heroin addiction took the place of the former deviant youth subcultures from the 1960 s and 1970 s. In retrospect, these youth subcultures may be seen as a pre-eminent expression of that particular period of time. Like anywhere else in the Western world, young people became economically more independent, resulting in greater freedom from the dominant culture. Different modalities of youth subcultures emerged, but it was specifically some of these which were to encourage, among other things, hard drug use. These subcultures functioned as necessary conditions for the beginner to progress toward a hard drug career.

\subsubsection{Autochthonous white youth}

We distinguished three distinct types of addicts among the white male Dutch drug users: the cultural rebels, the weekend adventurers, and the social marginals (Janssen and Swierstra 1982).

The cultural rebels, probably because of their middle class background and some education, were subculturally orientated toward self-development and individualism. Like the old hippies, they emphasized subjectivism and a spiritual escape from the status quo. For them the drug lifestyle was a full-time job. After years of addiction, experimental rule-breaking turned into criminal behavior.

The second category, the weekend adventurers, came from the working class with its material limitations and with a culture of the desirability of a respectable workers' life. For these people, regular work and family represented the core values. This particular subculture embraced values like masculinity, solidarity among men, vandalism for kicks, and the use 
of alcohol and amphetamines. Deviance, for them, was a form of social escape. Their addict life was dominated by feelings of ambivalence. While living a heavy and criminal junkie life, they retained parents, a stable job, and the clean society as their positive frame of reference.

The social marginals were characterized by a structurally marginal background (i.e., parents with little education, often unemployed), often dating back generations. For them, their primary contacts with conventional society were with police and the courts, rather than with the institutions of education and the labor market. From an early age, these were street-wise youngsters, involved with non-drug-related criminality. Subcultural values of "old hands in the business" of criminality were accompanied by a sharply demarcated us/them perspective toward conventional society. As an addict, one was fully integrated into the hard drug subculture, culturally as well as economically.

The white Dutch females in our study came into contact with hard drugs through the predominantly masculine subcultures. We distinguished two types: the home-leavers and the social marginals. First, the home-leavers had either a middle class or working class background, with traditional gender expectations. Within their female role, social independence through formal education and/or a job would be only temporary; getting married and raising children was their long-term conventional option. Getting involved with "alternative" boyfriends was a way of escaping from these narrow role expectations. Paradoxically, it turned out that there was not much room for independent female behavior for them as addicts in the masculine drug world. One could survive as an addict through relationships with dealers and competent junkies, or through prostitution; often that meant being dependent on the male friend's position in the drug world.

The social background of the female social marginals was comparable to that of their male counterparts, but their position was inferior. They were supposed to stay at home, and their parents were not interested in motivating them to do well at school or to get a decent job. A street-life among peers provided more esteem and a chance to act independently. Contacts with members of so-called ethnic minorities marked their deviance. The street-wise subculture entailed delinquent or semi-illegal skills such as prostitution. As addicts, their position in the drug world remained marginal. Conventional society existed mainly through social control institutions. 


\subsubsection{Black and brown youth}

Surinam is a former Dutch colony in South America. During the years preceding its independence in 1975, many young Surinamese people in their teenage years came to Holland. As in many other Western countries, problems resulting from their immigration primarily consisted of inadequate socio-economic opportunities (education, work), and the weakening or even disappearance of the extended family and related forms of informal social control. Instead, the street-corner culture of Surinam revived as a deviant phenomenon in the streets of the big cities of Holland. The street-corner culture offered them protection against their alienated existence as an immigrant. In addition to this cultural function, the subculture also offered economic opportunities such as drug-dealing, mostly at street level. This development was facilitated by the fact that in the 1970s the Dutch retail market for heroin was still expanding. Consequently, the tradition of "hustling", known from Surinam, was continued.

Surinamese drug careers can be differentiated into three groups; the hangers-on, the quarter-ounce dealers, and the home returners (Janssen and Swierstra 1982).

The hangers-on already belonged to the lower socio-economic class in Surinam. Their education and labor skills were very low, and after arrival in Holland, marginalization set in quickly. Hustling and smoking and dealing marihuana were regular activities. Hard drugs were viewed as an - albeit strong - kind of marihuana. Throughout years of heroin addiction, the original street-corner subculture remained the only social system in which they actively participated. For this group, conventional society remained at a great distance.

Among the quarter-ounce dealers the socio-economic position of the family and the level of their formal qualifications were somewhat higher. They were partly successful immigrants, and they saw opportunities to further improve their material wealth through illegal activities. Regular work was supplemented by joining their "own culture", the Surinamese street-corner subculture. These people were well suited to being middlemen in drug dealing: they had some knowledge of Dutch society; they had a place of their own, or at least were free of too much parental control; and they had earned enough capital to start a business. As addicts, they were also rather successful immigrants.

The home returners became well integrated into Dutch society, both economically and culturally - until the street-corner culture emerged. Because of their education and/or employment, this group lived within the mainstream Dutch society for years. However, the development of new 
problems in life, such as the pressures of living up to the image of being a succ essful immigrant, led to a turn to the Surinamese street subculture. For this group, cultural identity became a major preoccupation. After years of addiction, the position of these people was still marked by ambiguity. Although they had reclaimed their Surinamese roots, the conventional ties to institutional Western society had not been totally severed.

Research has also been done on drug use among another ethnic minority group in the Netherlands: people from the South Moluccas, an Indonesian island (Blom and Janssen 1987). Indonesia was a Dutch colony until the end of the Second World War; the Moluccans represent a special case for historical reasons. Many Moluccans served as soldiers in the Dutch colonial army, fighting against the Indonesians. After Indonesia became an independent nation, many South Moluccans were more or less exiled to Holland. Starting around 1950, the notion of establishing their own state, independent from Indonesia, became their focal concern. Over a period of time, however, political reality changed. The children of these Moluccans, born in Holland in the 1950s, encountered problems typical to second-generation immigrants. Frustrated in their original national aspirations, some of them turned to radical political action during the 1970s. The Dutch authorities responded rather severely to their political terrorism; and the original ideal lost much of its exciting appeal for new recruits into the political movement. Consequently, the political involvement of the South Moluccans diminished rapidly; one of the expressions of an "inner emigration" has been hard drug use.

This research on drug use among South Moluccans reveals certain similarities with the Surinamese hard drug addicts as discussed earlier. Here again, economic marginality and cultural problems were at the core of the addiction process. A significant difference between the two groups is, however, that the South Moluccans represented a historical specific generation of youth; a generation torn between Moluccan culture and Dutch culture. It is possible to distinguish two types of Moluccan drug addicts in the drug world of the 1970s: the Moluccan-oriented and the Dutch-oriented. For the Moluccan-oriented youth, deviance in relation to their parents still implied a social-cultural affiliation with Mollucan peers. Pre-drug delinquency was common. Typically, females came in contact with drug use through a Moluccan boyfriend. This group lived in ethnic Moluccan neighborhoods. To a certain degree, their involvement in drugs did cause a split, but even after years of addiction, they stuck to Moluccan relatives and culture as much as possible. Dutch dominant culture and conventional society were the real "them".

The Dutch-oriented youth rejected Moluccan culture. This group 
tended to have a somewhat more formal schooling than the Moluccanoriented addicts; their primary affiliation was with white subcultures where they encountered hard drugs. The females were involved with white boyfriends - in clear conflict with the expectations of the Mollucan extended family. As addicts, the men functioned side by side with both white and Surinamese addicts, often dealing in drugs for the closed Mollucan circles. Importantly, these addicts did not live in Moluccan neighborhoods; rather, they lived among autochthonous (white) Dutch people.

\subsubsection{Subcultural deviance of the 1970 s and drug careers}

We have shown how specific youth cultures in the 1970s encouraged the development of hard drug careers. In all cases, some form of deviance was already present prior to initiation into hard drug use. Initial hard drug use was consistent with an already established lifestyle of rules developed to respond to the problems of fighting an uphill battle with conventional society. Deviant drug careers were the result of this process. How the phenomenon of drug addiction developed after these first ten years is discussed in the next section.

\section{Incidence in the 1980s: Diffusion of social settings}

In a study of a more recent generation of youth who began to use heroin around 1980 (Swierstra et al. 1986), some interesting differences with earlier patterns were found. Generally, we observed a diffusion of the hard drug opportunity structure. It was no longer necessary to participate in any subcultural setting in order to become familiar with hard drugs. Of special importance was an increase in recreational hard drug use among various groups of youth. This trend was separate from the noted hardening of the marginal and criminal drug world.

The diffusion of the opportunity structure of hard drugs meant that the deviant career preceding the initiation into heroin use was generally shortened; young people arrived at hard drug use more quickly than before. Furthermore, the rationale for a life on hard drugs had become blurred and had lost its ideological focus. During the 1980s, a life on drugs became more of simply one of those lifestyles - one of several possible alternatives to choose from: heroin, why not (for a while)? In addition, this diffusion also manifested itself in a wider range of ages among users just starting; initiation into hard drugs occurred both at a younger and at an older age than previously.

Paralleling these developments on the consumer side, the supply struc- 
ture also grew significantly. For instance, hard drugs began to appear in social clubs, community centers and discotheques catering to mainstream youth. This resulted in a diversification of patterns of drug use. In addition to the stereotypical social outcasts with a completely deviant pattern of behavior, socially respectable youth experimenting with illegal substances appeared on the scene. For them, initial drug use had nothing to do with choosing any particular lifestyle. In this respect, the subcultural phase of the social history of the phenomenon of drug use has apparently become a relic of the past.

It is interesting to note that the process of de-ideologicalization of hard drugs resembles what happened to soft drugs some fifteen years earlier. For students and teenagers in the first half of the 1960s, hash and marihuana were a symbol of cultural rebellion within an esoteric subculture; in the 1970s, an expansion of the soft drug use took place among lower-class youth, marginal youth, and ethnic minorities. At the same time, people in their 30 s and 40 s, economically and socially integrated, continued their use outside any specific social-cultural users' setting. They smoked at home, after work, and with their neighbors when having a drink. It should be noted that this process of normalization or de-symbolization of soft drug use was one of the intended effects of the Dutch Opium Act of 1976.

The diffusion of hard drug use in the 1980s was characterized by the following: (1) reproduction of subcultures; (2) diversification of deviance; and, (3) individualization of drug use.

\subsection{Reproduction of subcultures}

The first trend was a replica of the subcultures of the 1970s among a new generation of 1980 s youth. For instance, our study again identified the category of "weekend adventurer" for a number of male drug users, and that of the "home-leaver" for a number of the females. There was one exception to this trend, however: the hippie subculture was gone. We found no instances where the cultural rebel has become involved in hard drug addiction.

\subsection{Diversification of deviance}

In the 1980s, a new category of marginal youth emerged. They came from a great diversity of socio-economic and cultural backgrounds; before their initiation into drug use, they were already regularly involved in delinquency. They were marginal with regard to the family, edu- 
cational system, labor market, and institutionalized forms of leisure activities. Their deviance was not directed against any specific sector of society (e.g., education or work), but rather evolved into a form of existence in its own right. Subcultures lost their power to recruit: a subcultural ideology was superfluous. For this category of youth, a life on hard drugs could fulfill several basic functions. First, it allowed them to acquire a social identity - something they lacked because of their marginal position in society. Second, hard drugs opened opportunities for an alternative, mostly criminal, career. And third, a life on drugs provided a rationalization for an already deviant lifestyle.

Our study showed a shift in pattern of use for the Surinamese young people between the 1970s and the 1980s. Most of the newly initiated Surinamese hard drug users had come to Holland at an earlier age than their predecessors in the 1970 s, often within a few years after birth. Consequently, these second-generation immigrants had become so westernized that they shared the same social settings as many of their white contemporaries. Their doorway to hard drug careers was through predominantly white youth settings, and followed the same path as the marginal white Dutch youth. Marginalization preceded first drug use. These young Surinamese people were found, together with their white peers, in diverse social groups with a deviant lifestyle.

Another ethnic minority appeared in the drug world of the 1980s: young people from Morocco. They came from North Africa mostly to join their fathers who had been working in Holland for several years; some of them came on their own, to find a materially better existence, or for reasons of more personal freedom. The social situation of the Moroccan youth closely resembled the Surinamese youth situation from a decade before: most of them came to Holland during their teenage years; they were in a marginal position because of their inferior educational and employment opportunities; their families had lost most of their integrity and control functions. The resulting vacuum was often filled by a street subculture characterized by "hustling" activities such as small-scale drug dealing, other forms of delinquency, and hard drug use. A life on drugs provided an alternative "career", preferred over an alienated existence in Western society. Family reunions in the Western country caused additional problems, especially between son and father; some youth left home at an early age. Studies in the cities of Amsterdam (Van Gelder and Sijtsma 1988), Rotterdam (Intraval 1989) and Utrecht (Kaufman and Verbraeck 1986) showed that a strikingly large number of young Moroccans were living a more or less nomadic urban life, forming relatively tightknit groups sticking together, quickly integrating newcomers. 


\subsection{Individualization of drug use}

The other new variant of drug use was based on the role that the use of various drugs had taken in the recreational activities of otherwise "respectable" youth. In the 1980 s, heroin had became part of the social setting of young people who had strong ties with conventional society. These young people had not developed a deviant way of life prior to their involvement in drug use. Their deviance was pretty much limited to the use of drugs, and was combined with family obligations, school and/or work. Their social background was mostly middle-class. There was no social-cultural involvement in the deviant drug world; they tried to abstain, as long as possible, from criminal income-generating activities. After years of addiction, the critical moment occurred when they had to make a decision in that regard; hard drugs now began to threaten their normality. For this group, addiction problems represented an isolated phenomenon within their predominantly conventional lifestyle (Swierstra et al. 1986).

We were not able to document this process of individualization of drug use in the life histories of the Surinamese youth. Indeed, for the Surinamese young people, problems of acculturation and cultural identity continued to play an important role in their life histories. Drug use still functioned to represent symbolically their deviance within conventional Western society.

Our observations regarding the white Dutch "respectable" user raise serious questions. For instance, was (is) this "socially respectable" category of hard drug users only a temporary phenomenon? Was the emergence of this type of hard drug user the result of Dutch drug policy (see below, paragraph 6). Or did this diffusion simply reflect the growing to maturity of the hard drug problem in Holland? The following takes a closer look at these (and other) questions.

\section{Deviant drug careers and conventional social bonds}

It is only to be expected that studies of the drug world will find drug addicts who have a deviant lifestyle, no matter what method of data collection is used. It is the addicts with a deviant lifestyle, after all, who are most easily identified. This was again the case in the recent study of Rotterdam (see Chapter 10). This study focused on persons who had been using opiates for less than two years at the time of the interview. Strikingly, these addicts either came from Moroccan backgrounds, or they 
went through a decidedly marginal, delinquent experience prior to their hard drug career. Delinquency was already a fixed pattern prior to their initiation into hard drug use. Of the 90 opiate addicts in this study, only eight (9\%) could be classified as non-criminal users: addicts who were not involved in crime at any time prior or during their hard drug career. For this small group, conventional bonds with society remained mostly intact. However, consistent with other studies, it was found that addicts with criminal involvement had not completely severed conventional ties with society either.

For addicts with relatively strong bonds with conventional society, the social distance toward a full-blown junkie life is greater than for those who do not (any longer) have these bonds. Addicts with ties to conventional society apply a double standard with respect to their way of life: the standards of both mainstream society and the drug world. In a sense, they lead a double life. They find justifications for their addictive behavior; for example, they view drug addiction as an illness, or as an unfortunate consequence of a wrong choice which blocks the way back to "normal" society. On the other hand, those who do not have strong bonds with conventional society have a much less ambiguous attitude toward being addicted.

Examination of the already discussed addict types in the 1970s and 1980s shows that commitment to conventional society may be weak or absent for several different reasons - with different implications for drug careers. It is possible to identify groups whose bonds with regular society are strong enough to keep them from persevering with a very long-lasting deviant drug career. Examples from the 1970s are: the "weekend adventurers" among the white Dutch males, the "home-leavers" among the white Dutch females, and the "home returners" among the Surinamese men (see above, paragraph 2). Youngsters involved in predominantly recreational hard drug use in the 1980 s form an additional category whose ties to conventional society remain fairly strong. However, we have also identified categories without such bonds with conventional society, where seriously deviant drug careers are a more plausible alternative: in the 1970s, the "social marginals" among Dutch males and females, and the Surinamese "hangers-on" (paragraph 2); and in the 1980s, the new marginal youth (paragraph 3.2 ). In these categories, to a high degree, their social position and their position in the drug world coincide. Regular society plays a subordinate role in their lives. 


\section{Drug careers in the long term}

The original dissimilarities between the different types of users do not necessarily produce totally different drug careers. Indeed, examination of the successive generations of addicts shows that, after the initial phase of the hard drug careers, there is a strong tendency to uniformity in career development. This may be called the "standard junkie phase". Based on the Rotterdam study, we distinguish several structural elements of drug addiction typical for the "standard junkie phase" (Intraval 1989). Nearly all addicts were not working at the time of the interview and they lived of welfare. Either they had never had any regular work or else they had lost their, usually temporary and unskilled, job. More than threequarters of the addicts had not finished their education. About nine out of 10 addicts was involved in some way with illegal forms of income generation. Virtually all addicts had been in contact with a methadone program some time during their addiction career. Their housing situation tended to be very unstable. Only very few had a partner who did not use drugs. Although one-third of the users had one or more children, only those with a non-using partner raised their child(ren) themselves. And finally, many of the addicts had had one or more clean periods in the course of their drug career, and relapsed. These structural similarities in addiction patterns were found in spite of the fact that there were very varying backgrounds prior to the onset of hard drug use. Thus, the determinants of the onset of drug addiction surely do not have to be the same as the determinants of drug careers in the highly active phase.

In order to understand the dynamics of drug careers in the long term, we conducted a follow-up study into the respondents of the 1982 study (Janssen and Swierstra) seven years later. The onset of hard drug use had been some 13 years before, in the 1970s. Through this research, we discerned three features of hard drug careers: mortality, abstinence and criminal activity. These features have also been described in studies in other countries, particularly the United States.

\subsection{Mortality}

Not every addict survives his risky habit. Specific immediate causes of death include a decrease in physical resistance, overdoses of the drug itself or of adulterated substances, suicide, violence, and AIDS. By inferring mortality rates from some 20 longitudinal studies from different countries, it was found that the mortality risk compared to non-drugtaking contemporaries is substantial: at least 10 times higher (Swierstra 
1990:78). In our sample of 90 addicts from several cities in the Netherlands, six deaths $(6.6 \%)$ have occurred since the first interview, seven years before. This is a rather small proportion compared to other countries, where about $12 \%$ mortality after seven years is common. A possible explanation for this relatively low mortality rate may be the relatively tolerant and pragmatic attitude towards drug use in Holland. As has been explained in other Chapters, Dutch drug policy places emphasis on health care, rather than on repression and criminalization. For instance, many addicts are involved in outpatient methadone maintenance programs including basic medical care. Furthermore, there is also a large safety net of welfare facilities in Holland. This enables addicts to stay visible for drug care and other welfare programs, without being forced to kick their habit or else go to prison. These factors may promote the continuation of moderate drug lifestyles over an extended period of time - more so than in other countries.

Provisional figures for HIV among Dutch drug addicts indicate that they are rather low, compared to other European countries and the United States. We speculate that the higher visibility of the Dutch addict is of great importance here: education and prevention programs as well as needle exchange projects seem to contribute significantly to the containment of the HIV virus. Finally, the number of violent deaths in the Dutch drug world appears modest, especially when compared to the United States (Swierstra 1990:126).

\subsection{Abstinence: quitting drug life}

A classic thesis in the field is Winick's "maturing out" (1962 1964): most drug addicts naturally stop before reaching their mid-30s. Winick's figures seem to be too optimistic, however. Our review of some dozens of hard drug studies, primarily from the United States and England, indicates a much lower rate of abstinence: less than $40 \%$ will have terminated use 15 years after first use. Around the mid-30s, only approximately one-third of drug addicts will have stopped altogether. In our study we defined as genuine abstinents those who had not been using drugs for at least one year while "on the streets", (i.e., outside prison or clinic). By this standard, after seven years, about $25 \%$ could be defined as having terminated their drug careers (Swierstra 1990:135).

Our findings are consistent with the results of our review of other studies, conducted in other countries. We speculate that this points to an empirical regularity: in Western countries, the proportion of addicts who terminate their career after several years is fairly constant (around 25\%). 
Contrary to the noted differences in mortality rates, termination rates may point to a more general pattern. This general pattern suggests that national or historical differences may not be very significant in determining termination rates; more importantly, perhaps, this empirical regularity may transcend the effects of various drug policies as well. This pattern cautiously suggests that the traditional medical notion of a natural history of drug addiction should not be neglected (see also Stall and Biernacki 1986:18).

Not unlike other studies, our study revealed varying pathways away from drug addiction among the sample: the temporary substitute addiction to alcohol, the abstinence-oriented therapeutic drug treatment, and accidental situational changes. In all cases, a gradual process of transition seems to occur into a more conventional way of life. The respondents in our study who had persisted in hard drug use often lived in Amsterdam and Rotterdam, two big cities with an extensive hard drug structure which is likely to make it more difficult to terminate drug use.

\subsection{Decreasing criminality, increasing conventionality}

The criminal behavior of the hard drug addicts in our studies has shown a clear pattern over the years. About only half of the sample had committed a serious criminal act prior to addiction; however, during drug addiction, most addicts were criminally very active. The high-activity criminal phase of the drug career typically lasted about 10 years. The last few years of the follow-up study, however, unmistakingly showed decreasing criminal activity, not only among the former addicts who had terminated their drug use, but also among a large number of those still addicted. The ex-addicts had stopped using drugs after eight years, around the age of 27 . For this group, termination of drug use implied immediate cessation of criminal behavior. Those who were still addicted at the time of the follow-up study (average age was slightly over 32) had a drug career of over 13 years behind them. Their ongoing addiction notwithstanding, their involvement in criminality generally ceased between the ages of 30 and 35 . Also among this group of addicts, a certain stabilization in their lifestyle took place, in anticipation of the termination of their criminal career. In this respect, their involvement in criminal behavior appeared to be independent of their drug career (Swierstra 1990:178).

Those still addicted may not end their drug career before their $40 \mathrm{~s}$, if ever. The older drug addicts stay in outpatient methadone maintenance programs. In addition to the daily dose of methadone, they are more 
likely to use alcohol and pills, rather than the more difficult to obtain substances of heroin and cocaine. Heroin and cocaine are expensive and demand a high level of income-generating crime. After years of police and prison experiences, the older addict now increasingly becomes concerned with trying to avoid further contact with the legal system. They have the option of using sedatives and barbiturates prescribed by the general practitioner; there is no longer the need for crime to support one's habit. Consequently, apart from their ongoing addiction, their way of life begins to differ less and less from that of people who have never used drugs. They are unemployed and have remained relatively uneducated for all these years; the lifestyle of the drug world provided an enticing alternative. However, once the bonds to the deviant drug world begin to weaken, what remains is simply unemployment and little schooling. They are now members of the lower-class, but they have lost the solace, comfort, and illusions hard drugs used to provide. Only when welfare payments are received (once a month), do they have the fleeting joy of a dose of heroin and/or cocaine ( $c f$. Preble and Miller 1977). As part of the adjustment process, the conventional bonds with significant others outside the drug world begin to intensify: they renew contacts with relatives, start their own family life with partner and children, and establish social contacts within their neighborhoods. Gradually, these ties with the conventional world are substituted for the old bonds to the drug world.

In conclusion, in the sample under study (both ex-addicts and current addicts), there is an ongoing process of steady decrease in criminality and a steady increase in abstinence rate. Intensification of conventional bonds keeps these people from relapsing into their previous, criminally addictive, behavior. The ex-addicts do not only strengthen their ties with significant others in conventional society, but to the education and job market as well. Accompanying this is a conventional turn in moral beliefs: the rules of the existing social order are increasingly accepted. We may then conclude that, in the end, the vast majority of drug addicts appears to dissolve into conventional Dutch society.

\section{Developments in the light of Dutch drug policy}

\subsection{Drugs and the spirit of the times}

In the 1980s, public opinion on hard drugs in Holland shifted to the problem-causing behavior of the addict. In the $1970 \mathrm{~s}$, a hard drug user was viewed primarily as somebody experimenting with a cultural alternative way of life; during the decade of the 1980 s, they were viewed as 
criminals and/or psychopaths. Scientific research put more emphasis on the criminality and public order aspects of drug problems. The policy counterpart was a more criminal justice oriented approach to drug problems, where the individual addict is held more personally responsible for drug-related problems. Methadone maintenance programs (the traditional pt:olic health response) are now complemented by a well-coordinated criminal justice response to their income-generating criminality and other public order problems. For instance, Amsterdam and Rotterdam developed projects designed to remove the annoying drug addicts from the streets; more so than before, the public prosecutor played an important role in these efforts.

The shifts in scholarly and policy focus are consistent with the current mood, both nationally and internationally. The American "War on Drugs" exemplifies the more repressive, less tolerant approach to the drug problem. In addition, as a product of European unification, more uniform (and quite probably, more repressive) international rules are forthcoming for the Netherlands. Yet, the Dutch approach to drugs remains characterized by several unique features.

\subsection{Extent and nature of recent Dutch drug problems}

Looking back over the past few decades, we may conclude that Dutch drug policy has possibly had a distinct effect on the character of drug problems in Holland. In terms of available figures, it seems that the pragmatic national policy did not produce the results that some of its hardline opponents predicted: i.e., higher numbers of addicts. Neither international comparisons, nor developments within the Netherlands over the last two decades, could reasonably justify such an inference. Qualitatively, the effect of the Dutch drug policy may be assessed as follows. First, the use of heroin was tolerated in Holland, particularly in the larger cities. This policy was consistent with the intent of the 1976 Opium Act which was designed to avoid the marginalization of the user by concentrating on drug dealing and drug-related crime. Complementary to this approach is a policy emphasis on the health care of the addict. It seems reasonable to conclude that these conditions may have facilitated experimenting with hard drugs, particularly for those young people who otherwise would not have become involved in a deviant way of life. (In paragraph 3.3 we described this process as a component of the individualization of drug use.)

A second and related hypothesis is that the easy availability and the nature of the methadone maintenance programs in Holland have con- 
tributed to the Dutch drug problem. The highly visible Dutch addict, who is able to avoid withdrawal symptoms from heroin through easy access to low-threshold methadone programs, may have weakened the deterrent effect which normally radiates from a "dope fiend". Perhaps the image of a marginal and tough criminal drug life has been softened. Following this line of reasoning, for some of the experimenting drug users (particularly those from middle-class social backgrounds and/or with a lack of criminal experience - those who actually might have been deterred by the prospect of legal sanctions and/or a miserable life), the Dutch policy may have made it easier to become more involved than it would have been under a tough, repressive, drug policy.

Of course, in the final analysis it is simply impossible to determine exactly the effects, if any, of the specific Dutch approach to drugs on the nature and extent of the drug problems in Holland. What can be established, however, is that a higher degree of acceptance of the drug addict by society implies a higher visibility of the addict for conventional society, and vice versa. We expect that this will affect drug careers, especially in the long term. It is not the highly deviant and criminally highly active phase of the drug career which makes for important international differences; of more interest is what happens after this phase, when the curve of deviant vitality in human lives takes a downward turn. Our findings on long-term opiate addicts in the Netherlands illustrate this point.

\subsection{A Dutch variant of drug careers?}

Methadone maintenance programs may be an important condition for addicts in order to retain their bonds with institutional society over the years, or in order to repair them, after many years. Methadone maintenance programs reach the majority of the addict population in the Netherlands. Recent Amsterdam and Rotterdam studies indicate that every year about $70 \%$ of opiate addicts are involved in one of these programs (Intraval 1989:12). In addition, there is the safety-net of general welfare facilities in Holland. We may speculate that in countries with a more repressive drug policy it would have been very hard to find a substantial number of addicts in their 30 s who are no longer criminally active, as we did in our study. In countries other than Holland, we would expect them to be either a criminally active drug addict, to have terminated their drug habit altogether, or, of course, to be dead. Moreover, prison sentences in countries like the United States are significantly longer than in the Netherlands. Dutch policy keeps addicts out of prison for most of the time during their active drug-using career. 
As we already noted, the termination rates in Holland do not seem to differ from the international picture; however, mortality rates are lower in Holland. Addicts are "on the streets", i.e., out of prison most of the time; yet, the criminally active phase of their drug-using careers appears to be more limited than elsewhere. In short, Dutch drug policy may, possibly, keep people addicted for a longer period of time, but in a more socially integrated way. This variant of the hard drug career might then be termed a product of the Dutch welfare society and its pragmatic drug policy.

\section{Conclusion}

The Dutch drug phenomenon has past its infancy; the subcultural phase in the social history of the phenomenon belongs to the past. The world of hard drugs has become tougher, more criminal, and is fought by law enforcement agencies more severely than ever before. However, compared to other Western countries (particularly the United States), Dutch drug policy is still pragmatic. The Dutch addict is kept socially visible by treatment and care programs. The shift in the direction of a more unambiguous approach over the last few years has resulted in a further articulation of the pragmatic, "normalizing" aspects of Dutch drug policy. Two important components of this policy are: the prevention of marginalization and of further criminalization; and the maintenance of a livable situation for all parties, including the addicts.

Dutch drug policy is gaining in popularity in other Western countries and the United States. To a large extent, the AIDS epidemic (especially among non-deviant groups) and the relative success of the Netherlands in containing the spread of the HIV virus is responsible for the growing appreciation of the Dutch approach to drug control. Indeed, some skeptical voices have expressed the fear that the international appreciation of Dutch drug policy may not survive the invention of the first effective medicine against AIDS. In our view, however, apart from its apparent success in the fight against AIDS, the unique Dutch approach to drugs deserves an open-minded, non-biased, and fair evaluation. In comparison to recent developments in other industrialized countries, Dutch drug problems have remained relatively minor, both quantitatively and qualitatively. At the very least, Dutch drug policy has not resulted in a fast escalation of the drug problem. 


\section{References}

Abrams, Ph.: Historical Sociology. West Compton House: Open Books, 1982

Becker, H.S.: Outsiders; Studies in the Sociology of Deviance. New York: Free Press, 1963

Biernacki, P.: Pathways from Heroin Addiction; Recovery without Treatment. Philadelphia: Temple University Press, 1986

Blom, M. and Janssen, O.J.A.: Molukse Heroïnegebruikers in Nederland; een Typologie van Levensstijlen van Molukse Heroïnegebruikers. Rijks Universiteit Groningen, 1987

Cohen, P.: Cocaine Use in Amsterdam in Non-Deviant Subcultures. Institute for Social Geography, University of Amsterdam, 1989

Des Jarlais, D.C. and Uppal, G.S.: Heroin activity in New York City, 1970-1978. American Journal of Drug Alcohol Abuse 1, 3, 4, 335-346, 1980

Inciardi, J.A.: The war on Drugs; Heroin, Cocaine, Crime, and Public Policy. Palo Alto: Mayfield Publishing Company, 1986

Intraval (Bieleman, B., Bruggink, G. and Swierstra, K.): Hard Drugs en Criminaliteit in Rotterdam. Groningen: Intraval, 1987 (Separate extended summary in English: Hard Drugs and Crime in Rotterdam. Groningen: Intraval)

Janssen, O.J.A. and Swierstra, K.: Heroïnegebruikers in Nederland; een Typologie van Levensstijlen. Rijks Universiteit Groningen, 1982

Janssen, O.J.A. and Swierstra, K.: Heroinegebruikers in Nederland; een Typologie van Levensstijlen. Rijks Universiteit Groningen, 1987

Kaufman, P. and Verbraeck, H.: Marokkaan en Verslaafd; een Studie naar Randgroepvorming, Heroinegebruik en Criminalisering. Gemeente Utrecht, 1986

Korf, D.J.: Heroïnetoerisme. 11: Resultaten van een Veldonderzoek onder 382 Buitenlandse Dagelijkse Opiaatgebruikers in Amsterdam. Universiteit van Amsterdam, 1987

Lindesmith, A.R.: Addiction and Opiates. Chicago: Aldine, 1968

Maddux, J.F. and Desmond, D.P.: Careers of Opioid Users. New York: Praeger, 1981

Preble, E. and Casey, J.J.: Taking care of business - the heroin user's life on the street. International Journal of Addiction 4(1):1-24, 1969

Preble, E. and Miller, T.: Methadone, wine and welfare. In: Weppner, R.S. (Ed.), Street Ethnography; Selected Studies of Crime and Drug Use in Natural Settings. Beverly Hills, CA: Sage Publications, 1977

Stall, R. and Biernacki, P.: Spontaneous remission from the problematic use of substances: an inductive model derived from a comparative analysis of the alcohol, opiate, tobacco, and food/obesity literature. International Journal of Addiction 21(1):1-23, 1986

Swierstra, K., Janssen, O.J.A. and Jansen, J.H.: De Reproductie van het Heroïnegebruik onder Nieuwe Lichtingen; Heroinegebruikers in Nederland, Deel II. Rijks Universiteit Groningen, 1986

Swierstra, K.: Drugscarrières; van Crimineel tot Conventioneel. Rijks Universiteit Groningen, 1990

Van Gelder, P.J. and Sijtsma, J.H.: Horse, Coke en Kansen; Sociale Risico's en Kansen onder Surinaamse en Marokkaanse Harddruggebruikers in Amsterdam. I: Surinaamse Harddruggebruikers. II: Marokkaanse Harddruggebruikers. Universiteit van Amsterdam, 1988

Waldorf, D: Careers in Dope. Englewood Cliffs, NJ: Prentice Hall, 1973

Winick, C.: Maturing out of narcotic addiction. United Nations Bulletin of Narcotics 14:1-7, 1962

Winick, C.: The life cycle of the narcotic addict and of addiction. United Nations Bulletin of Narcotics 16:1-11, 1964 


\title{
VII. DRUG TOURISTS AND DRUG REFUGEES
}

\author{
Dirk J. Korf
}

\section{Introduction}

"Even the streets are of two kinds: the touristy shopping street cluttered with neon signs, and the long and narrow sidewalk alongside the canals, marked by a street light, docked houseboat, parked car, locked bike, and falling leaves. Often they are only a block apart; the two styles of Amsterdam side by side" (Holleran 1990:11).

The introduction of illicit drug use in the Netherlands after World War II is frequently associated with foreigners and migrants: older people from Chinese descent who continued opium smoking as they had done in earlier decades, American sailors, black jazz musicians from (former) Dutch colonies in the Caribbean smoking marihuana, American soldiers stationed in West Germany who came to Amsterdam to buy marihuana. These groups, however, did not significantly increase illicit drug use among the local population. Rather, the spread of illicit drug use in the Netherlands is primarily associated with youth tourism, which strongly influenced the atmosphere in the capital city of Amsterdam in particular.

Tourism is a primary and continuously increasing source of income in Amsterdam. ${ }^{1}$ In the 1960 s, a new kind of tourism emerged. Young people met at the National Monument in front of the Royal Palace and in the Vondelpark. They slept in the open air. Within a short period Amsterdam became the European capital for the hippie generation. Sleeping in the open air was not particularly appreciated by the local authorities, and soon cheap alternative sleeping accommodation became available in houseboats, youth hostels and a municipal sleep-in. Youth tourism strongly contributed to Amsterdam's new reputation of being the largest drug metropolis on the continent.

This Chapter addresses a particular type of marginal youth tourism: frequent heroin users. After a short historical overview, findings from a field study among foreign daily opiate users are presented. Travelling behavior will be explained by a push-pull model. Special attention will be paid to political complications and the effects of a specific policy directed towards heroin tourists. Recent developments are summarized and explained by the local drug policy and shifting perceptions abroad 
of what has been called "the Dutch experiment" (Baanders 1989; Kaplan 1984).

\section{From drug mecca to last stop}

Until the mid-1960s illicit drug use was not perceived as an important social problem in the Netherlands (De Kort and Korf 1992). However, significant changes took place at the end of that decade. Arrests by the Amsterdam Narcotic Squad for possession or dealing rose steeply: 15 in 1961,34 in 1965, 451 in 1969. This increase of arrests continued up to the mid-1980s (more than 5,000 in 1985) and then decreased again to approximately 3,000 per year. Originally, it was mostly cannabis, but soon heroin, perceived as a much stronger threat to Dutch society, became a primary target for the police.

Although in recent years more than two-thirds of the arrests by the Amsterdam Narcotic Squad concern Dutch citizens (including a substantial number of Surinamese), until the mid-1970s, the majority of arrests involved foreigners (Korf and De Kort 1990). It is not only police data which indicates the importance of foreigners in contributing to the spread of illicit drug use in the Netherlands. In a study on American drug refugees in Amsterdam and London, the Dutch capital city was characterized as the "mecca for the turned-on" (Cuskey et al. 1972). Although the authors had discovered that the Dutch people did not especially want the drug tourists, they did note that "Amsterdam does not hate the turnedon crowd. It may wish that they would go somewhere else, but offers them more friendly tolerance and acceptance than perhaps any other city" (Cuskey et al. 1972:3). Next to American drug tourists, Italians, French, Swiss, Germans "....and long-haired representatives from many other countries" were observed (Cuskey et al. 1972:22).

In the beginning drug tourists were mainly hippies, restricting their illicit drug use to cannabis, LSD and other psychedelics. Social workers, doctors, nurses and, more typically, lay people were involved in crisis intervention. New and non-traditional institutions evolved, partly influenced by American experiments (e.g., the Free Clinic in San Francisco). They claimed more solidarity with youth than traditional institutions, were able to gain respect from policy makers and were increasingly subsidized by the local and national authorities (e.g., Leuw 1984). A common intervention was to "talk down" a tourist on a "bad trip" after taking LSD. Soon the helping professions were confronted with foreign opium and somewhat later, heroin users (Werkgroep 1972; Ten Have 1973; Koda 1975; Leuw 1973). 
Americans (hippies, soldiers deserted from Vietnam and bases in West Germany) and Germans belonged to the clientele of the first small-scale methadone program, initiated by the Jellinek Center. At that time, detoxification in West Germany was mainly restricted to inpatient treatment in old-fashioned psychiatric hospitals. The untraditional therapeutic communities and the Municipal Free Medical Care Program in Amsterdam had more German clients than Dutch (Hesser 1979; Koda 1975).

The "Deutscher Hilfsverein," a special center for social assistance to Germans in Amsterdam underwent drastic changes. For many years it had primarily helped tourists who had run out of money, elderly who wanted to return to their native country, and so on (Hesser 1983). Now they were confronted with a totally different group: youth tourists. In 1973 the center registered about 40 German heroin addicts among its clientele. In following years the number increased each year, reaching its peak at almost 800 in 1984.

Since the Netherlands went its own way in following a policy of decriminalization of cannabis use, it has been internationally criticized. Neighboring countries, West-Germany in particular, complained about the "lenient" Dutch drug policy, which was said to lead to an increase of drug abuse in surrounding countries. For example in January 1975 the state government of Northrhine-Westfalia requested that the Netherlands follow a more repressive policy towards cannabis, "...since it had been proven that these drugs meant the gateway to hard drugs". ${ }^{2}$ The substantial number of German heroin users in particular gave Amsterdam its reputation of being the "Drug Mecca".

For more than a decade, news about the Dutch drug policy in the German media concentrated on German addicts in Amsterdam, mostly to illustrate the failure of a so-called tolerant policy. This media-hype reached its peak in 1984, when the city council decided to start an experimental heroin-on-prescription program for extremely problematic users. Along with the news about "Free Heroin" and the increasing number of German drug deaths in Amsterdam, the city's reputation changed into "Endstation für Fixer" (last stop for drug users). "Behind the border they hope to find paradise. What a terrible misunderstanding. They drive to Amsterdam to die!" (Bach 1984). Often the situation of German heroin users in Amsterdam was presented as an illustration of inhumane liberalism and capitulation of Dutch drug policy (Goos 1979). However, young Germans seldom started their heroin career in Amsterdam. According to Hesser (1979), they "... not only carried their drug problem from Germany, but also problems with the Germans legal authorities".

On the other side of the border, in the Netherlands, irritation about 
German drug policy reached its peak in the mid-1980s. In 1975, a 26year-old Dutch man, who supposedly sold hashish to Germans in the Netherlands, was lured over the border by a German undercover agent. He was arrested and sent to prison. Prior to that incident Dutch citizens had been arrested in Germany for selling illicit drugs to Germans in the Netherlands, but now the first case was documented, where German police had been active in the Netherlands without the permission of the Dutch authorities (Volkskrant July 30, 1976). In the following years, several cases led to furor in the Dutch parliament and to diplomatic friction (Eikenaar 1986; Kaplan 1984; Rüter 1988). In addition, Dutch officials perceived the growing presence of the many German heroin users in Amsterdam as a direct result of the repressive drug policy in Germany, where methadone programs were completely taboo and treatment was almost exclusively restricted to inpatient therapeutic communities. German officials attributed this heroin tourism to the "lenient" and "liberal" Dutch drug policy. Within this context, German heroin users became the target of comprehensive political activism (Wimmer 1990).

\section{Towards a new policy}

During the 1970s, among professionals from service agencies there was a growing consensus about the necessity of minimizing access of foreign drug users to treatment facilities in the Netherlands. Foreign heroin users, as a general rule, were not allowed to participate in methadone programs and inpatient treatment programs, partly because of the fear that such services would encourage additional heroin tourists to come to Amsterdam, but also for financial reasons (who would pay the treatment in a drug free therapeutic community?). When in treatment, foreigners primarily participated in methadone programs run by a general practitioner, or they lived in one of the religious drug free communities (e.g., Jesus People).

During the following years, the local drug policy became more structured and coordinated (Leuw 1984). This had an effect on the treatment facilities for foreign heroin users. Because some of the Christian communities had closed, it became even more difficult for them to find treatment in Dutch drug free therapeutic communities. However, a number of general practitioners continued to prescribe methadone to a substantial number of foreigners. In fact, the means available to obtain methadone increased.

The Drug Department introduced its methadone-by-bus program at the end of the 1970s, mainly for Surinamese users and prostitutes (Vasseur 
1990). Methadone-by-bus was not intended as the first step towards a drug free life, but rather its primary objective was to reduce the risks associated with illicit drug use. Since heroin-using street prostitutes ran many health risks, foreign female users constituted a significant portion of the first generation of bus clients.

Although the City Council was aware of the phenomenon of heroin tourism, it did not implement a specific policy with regard to this particular segment of the heroin-using population in Amsterdam. This changed in 1984. The City Council decided that the public health orientation (e.g., low threshold methadone programs) and the repressive approach (tackling nuisance from street dealing and other drug-related crimes) should be integrated into a two-track policy. With regard to foreign heroin users, two specific goals were defined as part of a "policy of discouragement": to reduce their number and to decrease drug-related crimes. In order to realize these goals, methadone programs were supposed to "sharpen" their intake criteria for foreign users and the police should intensify their activities targeting foreign criminal users. In addition, officials visited a number of neighboring countries in order to explain the new policy to their counterparts and the media, thus hoping that foreign users would refrain from coming to Amsterdam.

The policy of discouragement was not a new invention. To some extent it had already been implemented by treatment facilities, but not as a consequence of official policy. Treatment staff had expressed some concern about the increasing numbers of foreign addicts. City officials had participated in a conference "Drugs over the Border", where German and Dutch experts extensively discussed the problems of German heroin tourists in Amsterdam (Goos 1979). After several years of discussion, in 1978 the City Council decided to financially support the "Deutscher Hilfsverein" - which had now changed its name to the Amsterdam Ecumenical Center (AMOC). Because the organization did extensive outreach work, it had a good reputation among German heroin users in Amsterdam. Also, it had built up a wide network of contacts with the legal authorities and treatment facilities in their native country. Many German heroin users in Amsterdam had a hard time surviving in the city and wanted to return to Germany. Because AMOC assisted German addicts in their attempts to return to their native country, the Amsterdam City Council decided to subsidize this agency.

The initiation of a new official policy with regard to foreign drug users in 1984 was based on a number of assumptions. First, Amsterdam was supposed to work as a magnet for foreign heroin users: they would come to the city because of its liberal climate, low drug prices and easily ac- 
cessible methadone programs. Second, it was assumed that foreign heroin users were responsible for a large part of the most inconvenient and annoying petty crime (e.g., shoplifting, theft of car-radios and bikes). Third, it was expected that a "tougher" legal approach would decrease the number of heroin tourists (Drugsbeleid 1985).

\section{An epidemiological field study}

Along with the introduction of the two-track policy, the City Council decided to implement a three-year drug research program. A field study among the so-called heroin tourists was a first priority, which clearly illustrates that the local authorities perceived the presence of foreign heroin users in Amsterdam as a serious problem. During April and July of 1985 and 1986 we interviewed four samples of approximately 100 foreign daily opiate users. ${ }^{3}$ Our study was guided by four main questions: (1) What is the size of the drug-using population and which are its main sub-categories? (2) Which factors explain why foreign users come to and possibly remain in Amsterdam? (3) How do they generate their income? (4) What are the effects of the policy of discouragement?

Very often studies among frequent heroin users relate to captive samples (e.g., inpatient treatment, prisoners, probation clientele, methadone patients). Consequently, the degree to which these samples are representative is often questionable. Apart from this general problem, in our case we had to assume that the target population was predominantly hidden and that heroin tourists were strongly under-represented in most of the captive samples ${ }^{4}$ Heroin tourists belong to a specific kind of hidden population; we introduced the concept of "floating population" to describe this particular group of people (Kaplan et al. 1990). Floating populations are characterized by their socio-geographic mobility. ${ }^{5}$ Most often, hidden populations are studied with a qualitative research orientation, e.g., ethnographic methods. In the drug field, ethnographers tend to concentrate on the most visible segments of the drug market. ${ }^{6}$ Therefore, from an epidemiological point of view the representativeness of findings is frequently questionable. ${ }^{7}$ Snowball sampling is a common method in qualitative studies, but methodological problems are often ignored and remain unsolved (Morrison 1988). In many studies, snowball sampling means not much more than recruiting new interviewees by referrals; i.e., with the assistance of those who have been interviewed already. A first methodological problem is: Where to start with the process of sampling? It has been suggested that chains of referral be initiated within as many different subgroups of the target population as possible (Biernacki 1986; 
Biernacki and Waldorf 1981).

The major methodological problems and possible solutions at this "zero stage" in snowball sampling have been extensively discussed by Watters and Biernacki (1989). First the districts in which to conduct the research must be defined (initial mapping). Second, extensive ethnographic mapping is necessary to uncover and analyze the social organization of target groups within the selected district. Third, an initial target plan for each district must be developed. Fourth, it is usually necessary to revise the target plans once in the field in order to meet social conditions and participation rates. During the last step, the preliminary findings shape research questions and instruments. This particular strategy was also applied in our study on heroin tourism. ${ }^{8}$ We decided not to initiate snowballs in methadone programs and the like. Instead first contacts were initiated at private addresses, in public buildings, cafes, in the streets, and so on. ${ }^{9}$ This could only be done by experienced field workers, who were not only familiar with specific districts, but who were also well-known to specific subcultures.

The next problem is: How to build up chains of referral systematically? In her study "Life in the Working-Class Family", Rubin (1976) applied the snowball technique. In order to limit the bias inherent to referrals, she asked the female interviewees to refer her to "the most distant connection" in the network instead of her closest friend. The Rubin method motivated us to look for a strategy that would help us to systematically avoid selection bias after the "zero stage".

In our study we introduced the concept of "randomized chain referrals". ${ }^{10}$ Respondents were asked to nominate the other heroin tourists known to them, with a minimum of five and a maximum of 25 names or nicknames. This was strictly confidential and respondents were not supposed to let us keep their list of nominees at the end of the interview. ${ }^{11}$ From this list we randomly selected the next respondent and asked the interviewee to assist us in finding that person. Although respondents were usually very cooperative in finding the selected nominee, it sometimes took us several days and nights of "hanging around" before this next respondent in the snowball chain was found.

This selection procedure resulted in rather heterogenous samples. The snowball sampling with randomized chain referral brought us in contact with types of users who had remained unknown to methadone programs and field workers (e.g., Italian housewives) and most would probably never have been reached with traditional snowball sampling procedures. Although this appears to be one of the great advantages of our method and suggests a substantial improvement in representativeness, we cannot 
claim that our respondents represent a fully random selection of the target population.

We used a multilingual structured questionnaire. Interviews lasted approximately one hour. Respondents were paid 25 Dutch guilders. ${ }^{12}$ With regard to reliability of the self-report data we found significant consistencies between scores on different variables (e.g., criminal career, illicit drug use). ${ }^{13}$

\section{Findings}

Among the 382 respondents we found 34 nationalities; $88 \%$ came from West-European countries. West-Germany, Italy, the United Kingdom and Spain were represented most frequently. One-third of the respondents were female. The largest nationality group, the Germans, consisted of $40 \%$ females. Ages ranged from 16 through 46 years, with an average of 27.4 years. Despite the dominant depiction of adolescents in the media (e.g., young heroin prostitutes), daily opiate use was found not to be a juvenile problem; minors actually were a rarity with the age cohort late 20 s/early 30 s most strongly represented.

Most respondents were (primarily) raised by their natural parents and only $4 \%$ grew up with their grandparents, in foster families or in institutions. All socio-economic classes were represented. About $40 \%$ reported lower class, one-quarter lower/middle class, and one-third upper/middle or upper class as their background. These percentages did not vary significantly between the four samples.

Although the respondents in the field study lived or stayed throughout the city, the highest concentration was found in downtown Amsterdam. Other concentrations were found in neighborhoods with lower quality housing and in renovation areas. ${ }^{14}$ Only one-quarter of the respondents said they were legally registered in Amsterdam. As far as respondents who had a place to stay were concerned, there was a wide variety in the quality of their housing. Some lived in clean and "bourgeois" apartments, while others stayed in dirty places without electricity, gas or water. Less than one-third had their own permanent address in Amsterdam; one out of ten was homeless.

In general, surveys do not allow us to reliably estimate the prevalence of frequent heroin use. ${ }^{15}$ Several other methods can be applied to estimate opiate use in a city. ${ }^{16}$ In our study, the number of heroin tourists per month was estimated with a capture-recapture technique and through extrapolation from the percentage of respondents participating in the Municipal Methadone Program. ${ }^{17}$ The best approximate estimate of the 
size of the population was 1,500 heroin tourists per month during the summer of 1985 and slightly higher in 1986. Although Germans made up the largest category (one-third), their number was much lower than assumed by policy makers. ${ }^{18}$ Italians constituted the second largest category; users from the United Kingdom were the third largest category. A secondary analysis of treatment and police data, together with mobility indicators from our field study, indicated that the number of heroin tourists decreased to approximately 800 per month during winter.

Respondents appeared to live rather isolated from the local population. Westermeyer (1982) came to the same conclusion with regard to western opiate users in Asia. For the majority of our respondents, other heroin users (mainly other foreigners) were the primary group of reference. Only a small category primarily lived in a world of non-users. ${ }^{19}$

Analysis of the snowball chains showed that nationality was an important variable in structuring the population of foreign users. Most respondents primarily lived within rather closed "scenes", basically limited to users from the same country and/or sharing their language. German users referred to other Germans; Austrians and Swiss - sharing German as their native tongue - were part of these snowballs. Italians also built a relatively separate group, although we found some overlap with users from other Latino countries (Spain, Portugal, Latin America). The Anglo population (UK, USA, Australia, New Zealand, South Africa) showed the strongest overlap with smaller "scenes" (i.e., Ireland, Scandinavia), although some others seem to be more restricted to one nationality (i.e., Yugoslavia, Greece). German female prostitutes appeared to be one of the most isolated groups within the population. ${ }^{20}$

Many respondents had a long history of illicit drug use; only $3 \%$ had a heroin career shorter than one year and one-third used heroin for the first time ten or more years ago. Apart from opiates, almost all respondents had been using cannabis and cocaine. Many also used LSD, amphetamines and pills (barbiturates, tranquilizers, and so on). The majority referred to themselves as heroin addicts, but only seldom had they been using heroin continuously. About one-third had had inpatient treatment. Half of the respondents had, at least once, kicked their habit voluntarily and did not do hard drugs, methadone or pills for a shorter or longer period; about one-quarter stayed "clean" for six months or more.

Approximately three out of four respondents were intravenous users. Application techniques correlated with nationality. Intravenous use was most dominant among Italians (94\%) and Germans (90\%). However, most respondents who used their first heroin in Amsterdam were non-intravenous users and preferred to chase the dragon ("to chinese"). 
The way respondents administer heroin correlated with the place where they used the drug for the first time. Experimenting in Italy and West Germany predominantly took place within a needle-oriented environment, whereas during initiation in Amsterdam other techniques (nasal, oral) were primarily learned. Only a minority of the respondents did not use drugs other than opiates. About half of the respondents reported cocaine use within the last 24 hours. The same was true for cannabis and more than one-quarter drank alcohol. Within the last seven days three-quarters of the respondents had used cocaine.

The data on recent drug use were analyzed for the combination: opiates (including methadone), cocaine, alcohol and pills: $20 \%$ had used three or four different drug types within the last 24 hours; $55 \%$ of the respondents used at least three of the four different drugs within the last seven days. ${ }^{21}$ These findings indicate that among daily opiate users in Western Europe, poly-drug use is highly prevalent and that "pure heroin addiction" is very rare.

\section{A push-pull model}

Heroin users in Amsterdam show a high level of mobility. Many spend more time in neighborhoods other than where they reside. They also frequently change apartments, and move to other parts of the country. A small segment is homeless for a longer period (Korf and Hoogenhout 1990). A considerable proportion of the interviewed heroin tourists had been living in Amsterdam for quite a while. Among the interviewed heroin tourists one-third were "short-term visitors" (maximum of 90 days), almost two-thirds were "settlers" (three months or longer for a minimum of four days per week) and a small percentage were "swingers" (they visited Amsterdam more than six times per year).

The presence of foreign users in Amsterdam has been explained by the relatively low drug prices and the availability of methadone programs. Our data do not support such theories. It is indeed true that there were no methadone programs in Germany at the time of our study, and that heroin and cocaine were usually more expensive in Germany than in Amsterdam (although prices in Frankfurt and Amsterdam were not significantly different). However, users from Italy made up the second largest group, in spite of the fact that heroin and cocaine were cheaper in Italy than in Amsterdam and methadone programs were available in most parts of Italy. Another reason to question the importance of low drug prices is that a significant price decrease for heroin and cocaine in most European countries between 1985 and 1986 did not reduce the in- 
flux of new drug tourists into Amsterdam.

In order to come to terms with the motivations of heroin tourists for coming to Amsterdam, a push-pull model has been constructed. Push factors relate to the reasons why they leave their own country, such as unemployment; unavailability of methadone; poor-quality heroin; and legal problems. The pull factors that theoretically could attract heroin tourists to Amsterdam include: job market, availability of methadone; high-quality heroin which is cheap and easy to find; relaxed atmosphere; and friends. Three categories of answers were given to the question "Why did you come to Amsterdam the last time?": (1) Liberal climate for drugs users; (2) Work and living; and (3) Legal and political problems.

With regard to the more liberal climate for drugs users, respondents mentioned the (supposedly) less severe harassment in Amsterdam as the main reason. In the words of a local police officer: "The whole lifestyle is different here, easier. They feel better here, life is more bearable. In Germany you are far more isolated as a user. It's the German mentality: if you don't behave as you should, you will be expelled."

Respondents who gave work and living as the main reason for their coming to Amsterdam were unemployed in their own country and came to find work in Amsterdam; others came to visit relatives or to join their partner. A female Italian user explained: "I came here about three years ago with my boyfriend. We wanted to earn a lot of money by working hard. I have always worked abroad. I wanted to work the whole year, also in wintertime, but this is not possible at home. There are no tourists in Sardinia. In Amsterdam we found work in a pizzeria."

The majority of the respondents who mentioned legal or political problems ran away from their country because they either, had to go to court, were on probation, had to go to prison or mandatory treatment; others were political refugees (i.e., from Iran, Chile). Legal problems were most frequently mentioned by the German users and least frequently by the Italians. A German user ( 30 years old) told the following story: "Since I was 15 law enforcement has been after me. They started "caring" for me before I even used heroin. Got caught with some hash. Every time they had their reasons: the probation officer who wanted to talk to me once a week, the therapeutic communities, prison, psychiatric hospital. They were always after me. They arrested me to force me to provide information about my dealer. He is an asshole and can be put in prison for a decade. But he could kill me, so I keep my mouth. Why don't they leave me alone, all I do is use drugs. I work for my money, do some drugbizz, was a prostitute. Why do they treat me as a criminal when I never steal 
or something. I did not come to Amsterdam to use drugs, definitely not, but I had no choice. I just want to live my own life."

Table 1 shows the results of our study. We classified the responses by whether the (push or pull) factor was drug-specific (e.g., price and purity of drugs) or non-drug-specific (e.g., employment). The push and pull factors have also been compared over time. That is, the responses regarding the reasons for the first visit to Amsterdam are compared with those of the last visit.

Table 1. Push and pull factors by first and last time in Amsterdam

\begin{tabular}{lcc}
\hline & $\begin{array}{c}\text { First Time } \\
(285)^{*}\end{array}$ & $\begin{array}{c}\text { Last Time } \\
(240)^{* *}\end{array}$ \\
\hline Pull Factors & $74 \%$ & $44 \%$ \\
* Drug-Specific & $22 \%$ & $32 \%$ \\
* Non-Specific & $52 \%$ & $12 \%$ \\
Push Factors & $10 \%$ & $24 \%$ \\
* Drug-Specific & $8 \%$ & $21 \%$ \\
* Non-Specific & $2 \%$ & $3 \%$ \\
Non-Specific Push and/or Pull & $17 \%$ & $32 \%$ \\
Total & $100 \%$ & $100 \%$ \\
\hline
\end{tabular}

*: These questions were only asked of the last three samples.

**: Forty-five respondents were interviewed after their first visit to Amsterdam.

Most of the reasons for visiting Amsterdam appeared to be not drugspecific: examples given were student visits and holidays with parents. Often the reported reasons could not be clearly categorized as either pull or push factors: examples include unemployment in their own country and hoping to find a job in Amsterdam. Whereas tourism and the general atmosphere in Amsterdam were important non drug-specific factors at the first visit, they played an insignificant role at the last visit. Work and housing gradually became more important. Among the reasons for the first visit, one-third could be categorized as drug-specific factors; among the reasons provided for the last visit, the importance of drug-specific factors increased to approximately $50 \%$ (i.e., $32 \%$ designated as pull factors; $21 \%$ designated as push factors). Drug-specific pull factors increased slightly (from $22 \%$ to $32 \%$ ); however, drug-specific push factors increased more strongly (from $8 \%$ to $21 \%$ ). A general conclusion is that the importance of non-drug-related factors decreases during the drug career, but they still remain important reasons for drug users to come to Amsterdam.

In summary, in our field study among heroin tourists, data concerning several drug-specific variables were collected and analyzed. The magnet 
effect (lower drug prices, methadone programs) often pointed out by politicians and the media could not explain trends in heroin tourism. Moreover, trends in heroin tourism often correlated positively with trends in general youth tourism: for example, the increase in Italian heroin tourists parallelled the substantial increase of Italian youth tourism in general. ${ }^{22}$ The respondents apparently were rather fond of travelling. They had often visited not only Amsterdam, but also other European metropoles (Paris, Barcelona, Berlin, Frankfurt, Rome). Almost onequarter, for example, had lived in London for at least one period of more than three months. While Italian users seem to reflect a general trend and to be part of the growing number of "youth tourists" from this country (non-drug-specific pull factor), German users left their country mainly because of legal problems (drug-specific push factor). A closer look at legal problems indicates that this pull factor might be even more important than Table 1 suggests. Before they came to Amsterdam the last time, $51 \%$ of the Germans had legal problems in their own country (problems with the police; were on probation; had to go to court, had to go to prison and/or into mandatory treatment), significantly more than the other respondents $(38 \%)$.

\section{Drug use and economic behavior}

The money spent on living (rent, food, clothes, etc.) during the last seven days preceding the interview varied strongly. While some users had a high standard of living, spending up to several thousands of guilders per week, others had hardly anything to eat. More than one-third of the respondents did not spend more than 100 guilders in the last seven days, while some could afford a luxurious lifestyle (expensive apartment, trendy clothes, Mercedes); the median was almost 200 Dutch guilders. The average amount of money spent on drugs (including alcohol, pills, methadone) in the last seven days far exceeded the amount of money spent on other living expenses. About one-quarter of the respondents did not spend more than 250 guilders on drugs during the last week; the median was slightly over 500 Dutch guilders.

Respondents were also asked how they had generated their income during the last seven days. We presented them with nine categories: work; sex business; welfare/unemployment; parents and relatives; drug business; pills and methadone; other illegal activities; and other legal activities. The source of income which generated the most money is defined as the primary source, others as secondary sources.

The drug business was the most important source of income. Four out 
of ten generated their primary income from steering, touting, copping and selling drugs and pills. Two-thirds earned at least some money this way. About half of the respondents received money from their parents, relatives or partner. Ten percent lived primarily off their partner and five percent off their parents or relatives. More than a quarter survived primarily (or secondarily) through work-generated income, other legal activities (street music, street theater, selling handmade jewellery, and so on) or welfare/unemployment. One-quarter of the respondents was supported by the sex business. For $18 \%$ of the respondents, prostitution or work in topless bars, floor and peep shows meant the main source of income. For $11 \%$ of the respondents, property crime was the main source of income and for another $15 \%$ these "other illegal activities" were a secondary source.

These findings do confirm that daily opiate use is strongly related to criminal behavior. The majority of the criminal activities, however, are to be categorized as "victimless crimes" (drug business and sex business). We found only one-quarter of the interviewees had committed crimes with victims (mainly property crimes) within the last week. As far as female users were concerned, they almost exclusively committed crimes without victims, in the sex business in particular (primary source for $40 \%$ of the females versus $9 \%$ of the males). Male users were mainly involved in earning money through drugs, but they also committed far more crimes with victims than females.

The economic behavior of daily opiate users is thus strongly dependent on gender. In addition, we found that users who were arrested some time before and/or after the beginning of the heroin career, and who also used alcohol frequently, were more likely to be involved in property crime. Respondents who (also) had been arrested for crimes other than violations of drug laws before they started using heroin reported property crimes as a source of income during the past seven days almost three times more than those who had not been arrested at all before their first heroin use. Users who had been in methadone treatment showed the opposite pattern. Respondents who did not participate in a methadone program were twice as likely to report property crimes than methadone clients.

During the field study, the official drug policy in Amsterdam with regard to heroin tourists was primarily directed towards reducing drug-related property crimes. A growing number of police officers were on the streets, where they kept the "scene" moving (Verbraeck 1988). The proportion of heroin tourists in the methadone program decreased. Our findings do not only suggest that a lower level drug dealing became more 


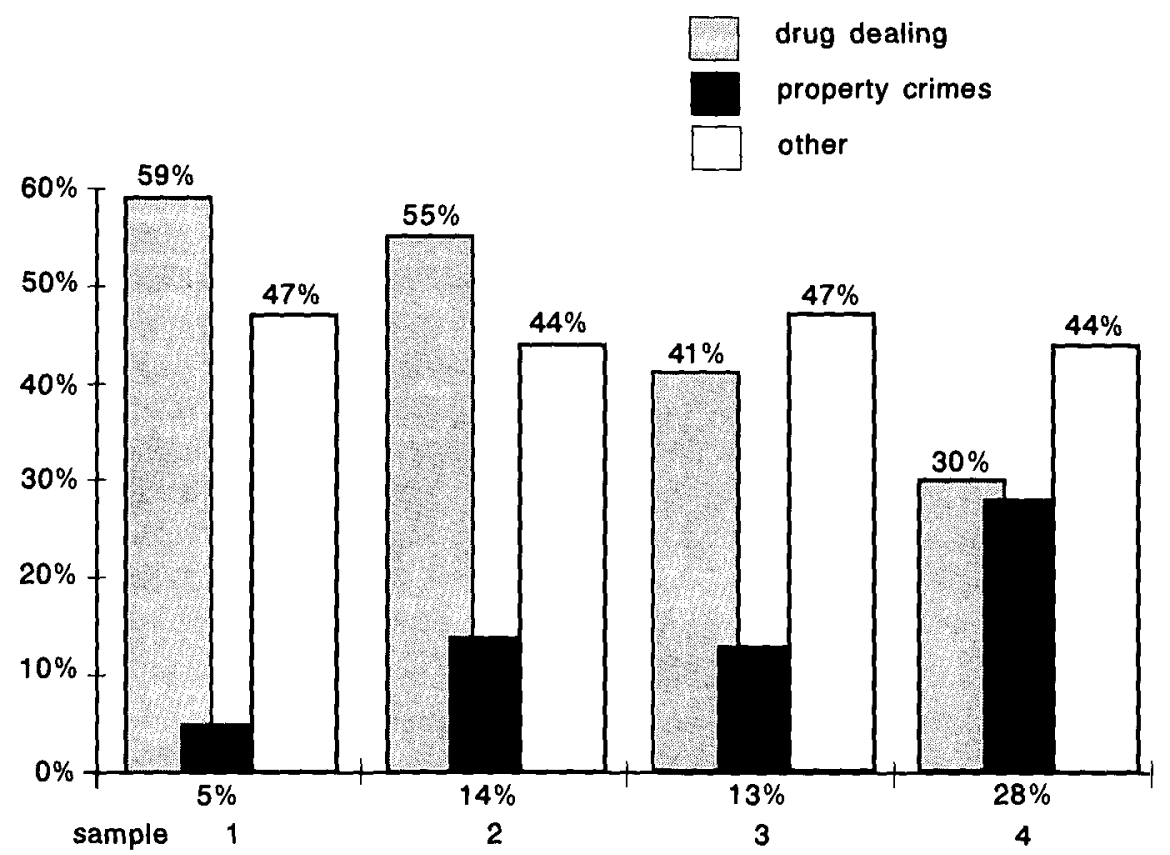

Fig. 1. Trends in main sources of income among male respondents.

dispersed throughout the city, but also that a decreasing proportion of the foreign users earned money in this branch. We did not find any significant change in economic behavior among females. ${ }^{23}$ However, as a result of increased police activity, several of the users who were formerly involved in drug dealing now shifted to property crimes. As a matter of fact, the percentage of male respondents generating income from the drug business decreased by half from the first to the fourth sample. The figures for property crime showed the opposite trend: the proportion of male respondents who primarily lived from "other illegal activities" was far higher at the peak of the tourist season (July) than at the beginning (April), but in the long run an increase could be clearly observed (Fig. 1). Although we have only collected data from two successive years, the findings are not consistent with the popular assumption that an intensified law enforcement policy leads to a decrease of drug-related property crimes. ${ }^{24}$ These findings were supported by later field studies in Amsterdam (Van Gemert 1988; Verbraeck 1988), showing that more police on the streets changes the structures of the drug market, but not necessarily reduces the number of dealers and users. 


\section{Recent developments}

In recent years reducing drug-related nuisance has become a major target of the Amsterdam drug policy. Much attention is paid to the prevention of social gatherings of heroin users and street dealers. Increased police patrol is one technique, renovation projects in order to improve the quality of housing in problem areas is yet another technique. Consequently, a lower concentration of dealers and users can be found in the most problematic streets. The increasing repression also had some important, and partly predictable, unintended side effects: users and dealers fled to other parts of the city as well as to other parts of the country (Verbraeck 1990). In particular, towns near the German border (Arnhem, Heerlen) have complained about increasing nuisance due to German heroin users. The so-called "ant smugglers" who used to buy small amounts of heroin and cocaine in Amsterdam apparently shifted to other cities, preferably closer to their home town. These users are very different from their counterparts in Amsterdam. In general they are not pushed out of their country because of legal problems, but they are predominantly small-scale dealers who come to buy drugs which are cheaper and of better quality than in their home town (Grapendaal and Aidala 1991). ${ }^{25}$ There are still German heroin users who come to the capital, stay for a short time, buy drugs and go back home, but the majority stays longer. Some have been living in Amsterdam for many years and often feel more Dutch than German.

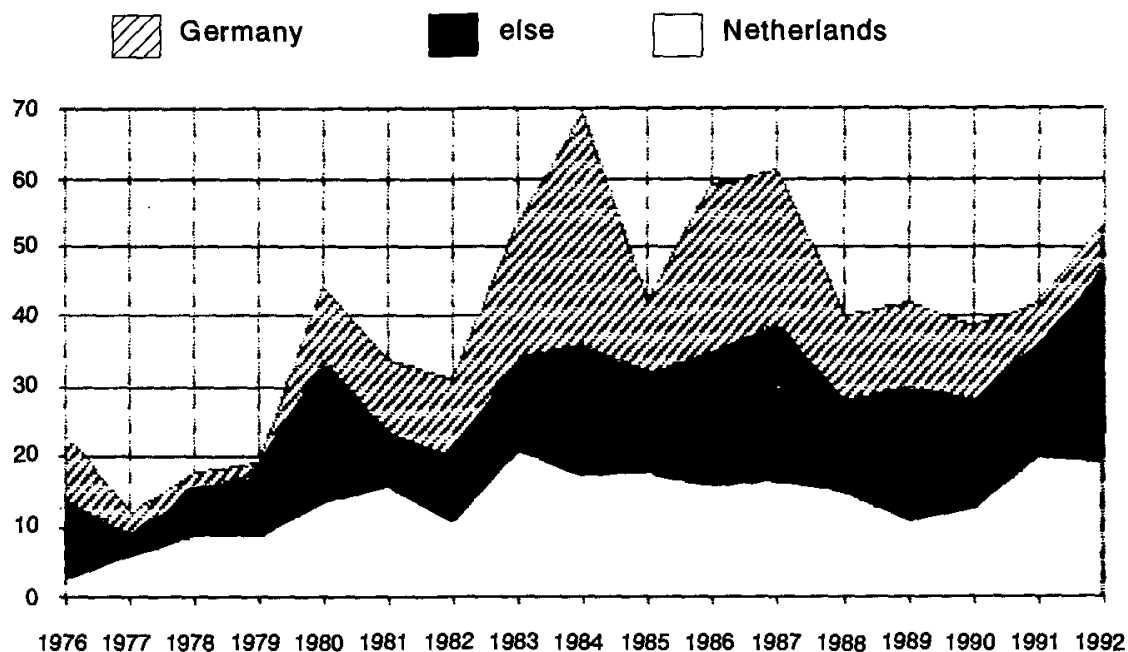

Fig. 2. Heroindeaths in Amsterdam by country of birth (1976-1992). 
Local authorities in Amsterdam claim that the number of German heroin users has decreased (Buning 1990). A significant decrease of German drug deaths seems to support this conclusion (Fig. 2). Some years ago more German than Dutch heroin users died in Amsterdam. In recent years, the number of German drug deaths has decreased. This trend could be an indication of a general decrease in the number of German heroin tourists in Amsterdam. However, there are several intervening variables. ${ }^{26}$ Firstly, most of the Germans who died did so within the first two weeks after their arrival (Cobelens et al. 1990). This means that "overdose" figures primarily relate to particular segments of heroin tourists, more so than to the population as a whole. Secondly, in recent years, more attention has been paid to the prevention of "overdose". Since the mid-1980s leaflets with instructions for foreign users of how to avoid a lethal overdose and how to help those who are in trouble ("keep them awake", "call an ambulance", "don't be afraid of the police") are distributed in youth hostels and other relevant locations. Also, ambulance personnel started using Narcan, an opiate antagonist; most probably this has saved lives. Thirdly, assuming that media news about suicides stimulates others to commit suicide, the local authorities stopped informing the media about every individual drug death. Instead of reporting every individual case, the number of drug deaths was reported only once a year. ${ }^{27}$ Fourthly, the purity of heroin in Germany has improved in recent years; differences in purity between Germany and the Netherlands have been presented as a major reason for the high number of German drug deaths in Amsterdam (Cobelens et al. 1990). Whereas the number of German drug deaths in the Netherlands has decreased, there has been a tremendous increase in drug fatalities in Germany (up to 1,463 in 1990). ${ }^{28}$

At the same time, the number of foreign arrestees and methadone clients has declined. But again, we are confronted with some complications when trying to interpret this. As mentioned before, the policy of discouragement was directed towards limiting the possibilities of foreigners to enter methadone treatment. Furthermore, the number of arrests is also consistent with the increased intensity of police activities. (Special police projects were carried out in downtown Amsterdam during the summer of 1986 and 1987 (Verbraeck 1990) and later implemented in a decentralized way in other neighborhoods.)

An additional factor confounds our attempts to make sense out of these different indicators: While the number of foreign drug deaths, methadone clients and arrestees has decreased, the number of German heroin addicts among the AMOC clientele has remained rather stable (approximately 
700 per year). Although drug policy is changing in Germany (methadone is no longer completely taboo; needle exchange programs were started in several cities), the push factors mentioned earlier still continue to exist. The AMOC annual reports indicate that German heroin users continue to run away from their country, mostly because of legal problems.

It seems that heroin tourists from Germany can roughly be divided into two categories: "swingers" who come to buy drugs in the Netherlands and others who run away from a problematic situation. For the first category, Dutch cities just across the border (Arnhem and Heerlen) are closer than German cities (Frankfurt am Main; Hamburg) where they can also buy heroin and cocaine relatively cheaply and of good quality.

Amsterdam is further away and it has become more difficult to buy drugs in the streets. ${ }^{29}$ Consequently, this kind of "ant smuggling" has shifted from Amsterdam to cities closer to the Dutch-German border. The second category does not come for quick transactions, but with the intention of staying in the Netherlands. These people apparently still prefer Amsterdam. Only a few German heroin users live in Arnhem and Heerlen; the same is true for Rotterdam and the other large cities.

Thus, German drug refugees still come to Amsterdam. According to the Municipal Health Organization, their physical condition keeps deteriorating: they often need inpatient treatment in a general hospital, many are seropositive and a growing number has AIDS (PPP 1989). It is probable that German heroin users in Amsterdam are a strongly selective subsample of the total population of heroin users in Germany. Many have legal problems in their own country, but only a few hundred of an estimated total of 100,000 German users come to stay in Amsterdam. Life in Amsterdam has become increasingly problematic, e.g., it is more difficult to participate in methadone programs (in particular those administered by general practitioners), their physical condition has become worse and the number of AIDS patients among them has grown (AMOC 1990). In a sense, their unfavorable situation in Amsterdam has evolved into a push factor itself: they seem more motivated to return to their home country.

Since December 1987 a special Repatriation Project has been funded by the German government. This project, in close cooperation with AMOC, has returned a few hundred German heroin users to their home country, e.g., to general hospitals, for inpatient drug-free treatment, or to their parents. This project symbolizes a shift in the political arena. Instead of blaming each other for their "wrong" drug policy, cooperation and mutual respect is growing. On World Drug Day, in June 1988, Professor Süssmuth (1989), then German Minister of Youth, Family, Women 
and Health, stated: "With its policy of discouragement towards foreign drug users Amsterdam lost its reputation of being the "Drug Mecca" some time ago."

Another explanation applies to the Italian heroin tourists in Amsterdam. According to the Municipal Health Organization their physical condition is significantly better and repatriation is much easier to realize (PPP 1989). They have fewer legal problems and methadone programs are not unusual in Italy. Moreover, most of the Italian heroin tourists in Amsterdam are "short stayers". Data from methadone programs, needle exchange programs and police arrests indicate a continuing growth of Italian heroin tourists (Buning 1990; Reijneveld 1991). This finding is consistent with the conclusions from our field study in 1986. Due to the higher level of inflation in Italy it has become more attractive to them to spend a holiday in the Netherlands. This tourism was strongly stimulated by Dutch tourist campaigns and travel agencies in Italy. In the last decade the number of Italian tourists in the Netherlands has increased from 105,000 in 1980 to 230,000 in 1989 (Heering 1990). Apparently, drug tourism can be a side effect of general tourism; this is particularly the case when the younger generations are involved.

\section{General outlook}

Heroin tourists were defined as foreigners who used opiates for at least six days per week. The users in our study had many things in common, but also showed significant differences. In fact, the term "heroin tourist" can be quite misleading. First of all, it was not always appropriate to define our respondents as "tourists". Some had been living in Amsterdam for a decade or more. Second and more importantly, many interviewees did not come to Amsterdam only because of heroin. If we defined everybody who takes drugs and travels as a drug tourist, then not many people would be excluded from our definition. We would have to define a large proportion of the Swedes taking the ferry to Denmark or Germany as alcohol tourists, many young people visiting Amsterdam as hash tourists, simply because they drink alcohol on the Swedish ferry or smoke hash in an Amsterdam coffee shop. If we restrict ourselves to heroin users, many travel rather frequently, not only to other countries, but also within their own country. A heroin user who lives in a town near Rotterdam will sometimes go to that city and buy heroin. However, he or she could also go to Rotterdam to do shopping or go to a concert. Consequently, most heroin users should be defined heroin tourists. Clearly, such a definition does not make much sense. I will not propose any alternative here; I just 
want to point out that labeling a person as an heroin tourist implicitly carries the risk of forgetting that his or her heroin use not always dominates daily life, but may be but one of many other characteristics.

In his novel "In the Dutch Mountains" Nooteboom (1984) pointed to something that strikes the eye of many visitors. "Dutch people do not merely meet; they confront each other. They bore their luminous eyes into another person's and weigh his soul. There are no hiding places. Not even their homes can be described as such. They leave their curtains open and regard this as a virtue." Illicit drug use is rather visible in Amsterdam. The same is true for prostitution and other social phenomena. This visibility easily leads to the conclusion that things are worse in the Netherlands. However, simply because in other countries the problems may not be as visible, it does not mean they do not exist. ${ }^{30}$

In general the reputation of Amsterdam's drug policy abroad has changed. It has gained respect for its public health approach: low-threshold methadone programs, syringe exchange, and so on. While the city of Amsterdam expands such harm reduction facilities, it does not like foreign users in its programs. There are some indications that the policy of discouragement has resulted in a smaller number of German heroin users in the city. On the other hand, they still come and stay in Amsterdam. This will most likely continue as long as the German drug policy is dominated by the paradigm of drug-free inpatient treatment and continues to be rather reluctant to implement methadone programs (Gerlach and Schneider 1991; Schneider 1989). This creates a major conflict in Dutch drug policy: harm reduction implies methadone for foreigners, whereas methadone programs are perceived as a stimulus for foreign users to come and stay in the Netherlands. It is undoubtedly far easier to decide that heroin tourists should be kept out of the domain of drug programs at the political (abstract) level than "down in the trenches". For doctors, nurses and social workers confronted with unsafe sex and unsafe use practices and other health problems it is not always possible to refrain from doing what they consider to be in the best interest of prevention and treatment.

Even when push factors in other countries would decrease significantly, it does not seem plausible that heroin tourism would completely disappear. As shown for the Italian subgroup, to some extent heroin users are not very different from "normal tourists". They like to travel and visit cities which are beloved by young people, e.g., London, Paris, Berlin, Barcelona and Rome. Consequently, heroin tourism is unavoidably part of general youth tourism and exists in all larger cities in Western Europe. 


\section{References}

Adler, P.A.: Wheeling and Dealing. An Ethnography of an Upper-Level Drug Dealing and Smuggling Community. New York: Columbia University Press, 1985

AMOC: Jahresbericht/Jaarverslag 1989. Amsterdam: AMOC, 1990

Avico, U. and Mariani, F.: Diffusione di Oppiacei e altre Psicodroghe e Profili degli Assuntori tra $i$ Giovanni della Leva Militare 1982. Rome: Istituto Superiore di Sanità, 1983

Baanders, A.: De Hollandse Aanpak. Assen, the Netherlands: Van Gorcum, 1989

Bach, K.: Sie fahren nach Amsterdam um zu sterben. Das Neue 45, November 5, 1984

Biernacki, P.: Pathways from Heroin Addiction; Recovery without Treatment. Philadelphia: Temple University Press, 1986

Biernacki, P. and Waldorf, D.: Snowball sampling: problems and techniques of chain referral sampling. Sociological Methods and Research 10:141-163, 1981

Brinkman, N.: Over Dood en Dosis. Een Literatuuronderzoek naar Sterfte onder Heroinegebruikers. Utrecht: NcGv-reeks 80, 1985

Buning, E.C.: Het Drugprobleem in Cijfers. Deel IV. Amsterdam: Municipal Health Service, 1990

Clayton, R.R. and Voss, H.L.: Young Men and Drugs in Manhattan: A Causal Analysis. Rockville, MD: NIDA (Research Monograph 39), 1981

Cobelens, F.G.J., Schrader, P.C. and Sluijs, Th.A.: Acute Dood na Druggebruik in Amsterdam. Amsterda m: Municipal Health Service, 1990

Cohen, P.D.A.: Cocaine Use in Non-Deviant Subcultures. Amsterdam: University of Amsterdam, Institute of Social Geography, 1990

Cuskey, W., Klein, A.W. and Krasner, W.: Drug-Trip Abroad: American Drug Refugees in Amsterdam and London. Philadelphia: University of Pennsylvania Press, 1972

De Kort, M. and Korf, D.J.: The development of drug trade and drug control in the Netherlands; a historical perspective. Crime, Law and Social Change 17:123-144, 1992

Drugsbeleid: Problemen, Taken en Doelstellingen. Amsterdam: Bureau Voorlichting van de Gemeente Amsterdam, 1985

Eikenaar, A.: Hoe Nederlandse drugshandelaars in de val worden gelokt. De Tijd, November 8, pp 8-11, 1986

Gerlach, R. and Schneider, W.: Abstinence and acceptance? A commentary on the problematic relationship between the German abstinence paradigm, low threshold oriented drug work, and methadone. Australian Drug and Alcohol Review 3, 1991

Glaser, B. and Strauss, A.: The Discovery of Grounded Theory: Strategies for Qualitative Research. Chicago: Aldline, 1967

Goos, C.: Drogen über die Grenze. Zur Drogensituation in den Niederlanden und der Bundesrepublik Deutschland. Probleme deutscher und niederländischer Drogenabhangiger im Nachbarland, pp 3-5. Arbeitsgemeinschaft für Jugendhilfe, 1979

Grapendaal, M. and Aidala, R.: Duits Drugtoerisme in Arnhem. The Hague: Ministery of Justice (WOCD), 1991

Hartnoll, R., Lewis, R., Mitcheson, M. and Bryer, S.: Estimating the prevalence of opioid dependence. The Lancet, January 26, 1985

Heering, A.: De Italianen komen! Intermediair 26(15):21-29, 1990

Hesser, K.-E.H.: Deutsche Jugendliche mit Drogenproblemen in Amsterdam. In: Drogen über die Grenze. Zur Drogensituation in den Niederlanden und der Bundesrepublik Deutschland. Probleme deutscher und niederländischer Drogenabhängiger im Nachbarland, pp 103-107. Arbeitsgemeinschaft für Jugendhilfe, 1979

Hesser, K.-E.H.: 100 Jahre Deutscher Hilfsverein in Amsterdam. In: Hundert Jahre Deutscher Hilfsverein. Amsterdam: AMOC/DHV, 1983

Holleran, A.: Gluurders in Amsterdam. Clique 1:11-15, 1990 
Johnson, B.D. et al.: Taking Care of Business. The Economics of Crime by Heroin Abusers. Lexington, MA: Lexington Books, 1985

Kaplan, C.D.: The une asy consensus: Prohibition and experimentalist expectancies behind the International Narcotics Control System. Tijdschrift voor Criminologie 26(2):89-109, 1984

Kaplan, C.D., Korf, D.J., Van Gelder, P. and Sijtsma, J.H.: Floating Drug-Using Populations in Europe: Comparative Reflections with the Americas. Proceedings of the Community Epidemiology Work Group. Rockville, MD: NIDA, 1990

Koda: Inventarisatie Rapport van de Projectgroep Buitenlanders. Amsterdam: Kontinu Overleg Drugs Amsterdam, 1975

Korf, D.J.: Heroine Toerisme II. Amsterdam: University of Amsterdam, Institute of Social Geography, 1987

Korf, D.J. and De Kort, M.: Drugshandel en Drugsbestrijding. Amsterdam: Bonger Institute of Criminology, 1990

Korf, D.J. and Hoogenhout, H.P.H.: Thuis op Straat. Amsterdam: GGZ-reeks, 1989

Korf, D.J. and Hoogenhout, H.P.H.: Zoden aan de Dijk. Amsterdam: University of Amsterdam, Institute of Social Geography, 1990

Korf, D.J., Mann, R, and Van Aalderen H.: Drugs op het Platteland. Assen, the Netherlands: Van Gorcum, 1989

Korf, D.J., Van Aalderen, H., Hoogenhout, H.P.H. and Sandwijk, J.P.: Gooise Geneugten. Amsterdam: SPCP, 1990

Leuw, E.: Drugsgebruik in het Vondelpark 1972. Tijdschrift voor Criminologie 15:202-218, 1973

Leuw, E.: Door schade en schande. De geschiedenis van drugshulpverlening als sociaal beleid. Tijdschrift voor Criminologie 28(2):128-136, 1984

Morrison, V.L.: Observation and snowballing: Useful tools for research into illicit drug use? Social Pharmacology 2(3):247-271, 1988

Musterd, S. and Kersloot, J.M.: Environmental Quality and the Perception of Drugs in Neighbourhoods in Amsterdam. Paper presented at the 16th ICAA Conference, May 30June 5, Lausanne, 1987

Nooteboom, C.: In the Dutch Mountains. Baton Rouge, LA: Louisiana State University Press, 1984

PPP: Passanten en Prostituées. Jaarverslag over 1988, evaluatie en onderzoek. Amsterdam: Municipal Health Service, 1989

Plomp, H.N. and Van Oers, M.L.: Roken, Alcohol- en Drugsgebruik onder Jongeren in het Nederlandse Euregiogebied. Amsterdam: Free Reformed University, Institute of Social Medicine, 1989

Preble, E. and Miller, T.: Methadone, wine and welfare. In: Weppner, R.S. (Ed.) Street Ethnography, pp 229-248. Beverley Hills: Sage Publications, 1977

Reijneveld, S.A.: Methadonverstrekking in Amsterdam in 1990. Amsterdam: Municipal Health Service, Epidoc, 1991

Rubin, L.: Worlds of Pain. Life in the Working-Class Family. New York: Basis Books, 1976

Rüter, C.F.: Die strafrechtliche Drogenbekämpfung in den Niederlanden. Ein Königreich für Aussteiger? Zeitschrift für die gesamte Strafrechtswissenschaft 100(2):385-404, 1988

Schneider, W.: Das deutsche Abstinenzparadigma am Scheideweg. Drogalkohol 13:104-116, 1989

Skarabis, H. and Patzak, M.: Die Berliner Heroinscene. Eine epidemiologische Untersuchung. Weinheim: Beltz Verlag, 1981

Sterk, C.E.: Living the Life. Prostitutes and their Health. Rotterdam: Erasmus University, 1990 (Dissertation). 
Süssmuth, R.: Amsterdam längst kein "Drogen-Mekka" mehr. Bonn: Pressedienst des Bundesministers für Jugend, Familie, Frauen und Gesundheit, 1989

Ten Have, P.: Jeugdtoerisme als Amsterdams probleem. Maandblad voor Geestelijke Volksgezondheid 28(9):375-386, 1973

Van Gemert, F.: Mazen en netwerken. Amsterdam: University of Amsterdam, Institute of Social Geography, 1988

Vasseur, P.: The Amsterdam Approach of the Drug problem. Paper presented at the European Conference on Drug Addictions, Barcelona, January 24-26, 1990

Verbraeck, H.T.: De Staart van de Zeedijk. Amsterdam: University of Amsterdam, Institute of Social Geography, 1988

Verbraeck, H.T.: The German bridge: A street hookers' strip in the Amsterdam Red Light District. In: Lambert, E.Y. (Ed.) The Collection and Interpretation of Data from Hidden Populations, pp 146-155. Rockville, MD: NIDA (Research Monograph 98), 1990

Watters, J.K. and Biernacki, P.: Targeted sampling: Options for the study of hidden populations. Social Problems 36(4):416-430, 1989

Werkgroep Verdovende Middelen: Achtergronden en Risico's van Druggebruik. Rapport van de Werkgroep Verdovende Middelen. The Hague: Staatsuitgeverij, 1972

Westermeyer, J.: Poppies, Pipes and People. Opium and its Use in Laos. Berkeley: University of California Press, 1982

Wiebel, W.W.: Identifying and Gaining Access to Hidden Populations. In: Lambert, E.Y. (Ed.) The Collection and Interpretation of Data from Hidden Populations, pp 4-11. Rockville, MD: NIDA (Research Monograph 98), 1990

Wimmer, F.: Tätigkeitsbericht 1989 Bundesprojekt Rückkehrhilfe. Münster, Germany: Landschaftsverband Westfalen-Lippe, 1990

\section{Endnotes}

1. The city has approximately 700,000 inhabitants. In 1989 almost eight million tourists were registered.

2. Northrhine-Westfalia is the German state (Bundesland) with the highest density of population. It is situated east of the Netherlands (Parool, January 22, 1975).

3. The target population was defined as non-Dutch persons who use opiates at least six days a week. Users from the Dutch Antilles, Surinam and Indonesia were excluded (since they are considered Dutch citizens).

4. According to Wiebel (1990:4) this term refers to "a subset of the general population whose membership is not readily distinguished or enumerated based on existing knowledge and/or sampling capabilities".

5. The mobility may be vertical (e.g. upward and downward social mobility in the drug trade) or horizontal (e.g. homeless).

6. For example, street prostitutes (Sterk 1990) or street dealers (Van Gemert 1988). Such studies can contribute to a better understanding of illicit drug use, lifestyles, networks, and so on, and may be applied to test hypotheses or to generate theories. Adler's exemplary study on upper level drug dealing clearly illustrates that ethnographic studies do not have to be limited to the visible segments of the drug market (Adler 1985).

7. This problem can be illustrated by two American examples. Is it legitimate to generate a developmental model from comparing a street sample of mainly black and Puerto Rican heroin users with a white sample ten years later, as was done in the famous study "Methadone, wine and welfare" (Preble and Miller 1977)? Can the contribution of heroin addicts to property crime in a city or country reliably be estimated from a sample interviewed in a store front in one of the most problematic neighborhoods in New York City (Johnson et al. 1985)? 
8. Dr. Patrick Biernacki, a medical sociologist from San Francisco, was very helpful in finding solutions for the zero stage problem in our study.

9. Next to ethnographic knowledge, the concept of theroretical sampling (Glaser and Strauss 1967) was very helpful to complete the process of mapping. For a more detailed description, see Korf and Van Poppel (1986) and Korf (1987).

10. At a later date, the same procedure was used in a study among frequent hard drug users in an urbanized region (Korf et al. 1990), and homeless youth in the inner city of Amsterdam (Korf and Hoogenhout 1989). In doing the field work for a study among non-deviant cocaine users (Cohen 1990), we applied a slightly different procedure.

11. In practice almost all respondents did give their list to us.

12. This is a virtual necessity if one wants to obtain cooperation and meaningful data from community-based research samples (Wiebel 1990).

13. A panel of $\mathbf{3 8}$ heroin tourists was followed for more than a year and interviewed every three months. Test-retest analysis indicated that they do not remember their exact age of initiation (first use of various drugs) but the mean scores for the whole panel were rather stable. Income and expenditures for drugs and living during the past seven days were measured by two different questionnaires; self-report data appeared to be quite consistent.

14. In a household survey on the perception of the spread of drug use over the city, Musterd and Kersloot (1987) presented some interesting socio-geographical theories to explain why drug use is more prevalent in such parts of a city than in others.

15. There are some exceptions. Avico and Mariani (1983) analyzed urine from a large sample of male Italian recruits; $1.7 \%$ of the urine samples were positive for opiates. Clayton and Voss (1981) conducted an extensive prevalence study in a High Drug Use Area in Harlem (New York City).

16. Skarabis and Patzak (1981) described a number of techniques based on the assumption that most users know each other. Estimates can be generated from statistical computations based on spacial distribution, e.g. the distance between the place users live (density estimates). This kind of method seems more useful for rural than urban areas. Another technique to estimate the prevalence of frequent opiate use is to extrapolate the size of the populations from indirect parameters, e.g. hepatitis and overdoses.

17. This technique stems from ethology and is known as the capture-recapture technique. In order to estimate the number of fishes in a lake, a first sample is caught. The fishes are tagged and put into the lake again. A second sample is caught, including tagged fishes from the first sample. Assuming that both samples are independent, the population size can be estimated $(N=n i * j n / n i j . ~ N=$ population size; $n i=$ size of sample $i ; n j=s i z e$ of sample $\mathrm{j}$; nij $=$ size of both samples $\mathrm{i}$ and $\mathrm{j}$ ). The capture-recapture technique was applied to the drug field by Skarabis and Patzak (1981) in Berlin and by Hartnoll et al. (1985) in London. In our case, the samples were foreign methadone clients in the Municipal Methadone Program and foreigners receiving methadone after arrest at police stations.

18. Their number was thought to be higher because they were greatly over-represented among clients in the methadone programs as well as among arrestees and drug deaths. Apparently, German opiate users have a higher risk of lethal overdose than other subgroups (Cobelens et al. 1990).

19. This finding results from the answers to the question: "Who are the five persons in Amsterdam you know best?" 
20. In later field studies we discovered comparable patterns. Surinamese users were mainly found in snowballs together with other Surinamese. The same was true for white Dutch users in Amsterdam. Although there was somewhat more overlap between the different ethnic groups in the local population of daily opiate users, we found that female prostitutes were rather isolated and seldom found in snowballs with non-prostitutes. Male prostitutes appeared to be more integrated in other segments of the heroin using population (Korf and Hoogenhout 1990).

21. The most prevalent combinations were: opiates and cocaine, but no alcohol or pills; opiates, but no cocaine, alcohol or pills; opiates and alcohol, but no cocaine or pills; opiates and cocaine and alcohol, but no pills.

22. Every year about 350,000 to 400,000 of those tourists ( $15-34$ years old) visit the Dutch capital. Between 1980 and 1986 the number of Italian tourists in youth hotels and youth hostels in Amsterdam doubled.

23. Prostitution remained the most important source of income. Police activities apparently did not substantially affect the number of female street prostitutes. Where did they have an affect? Women had to leave their working area in the Red Light District and move to a more dangerous public location (Verbraeck 1990).

24. In a later field study among local daily opiate users we found that those living from drug business, blacks in particular, were more frequently arrested than those living from property crimes (Korf and Hoogenhout 1990).

25. A similar phenomenon was found among Dutch users in rural areas (Korf et al. 1989; Korf et al. 1990)

26. Estimates on such a parameter are not very reliable (Brinkman 1985). Changes in purity, police arrests and (lack of) methadone treatment appear to correlate with mortality (Korf 1990).

27. This seems a trivial change in policy. Although it is not possible to estimate the proportion of suicides among drug deaths, suicide certainly plays a role (Cobelens, Schrader and Sluijs 1990).

28. (Badische Zeitung, January 4, 1991). This number does not include statistics from the former German Democratic Republic. Consequently, the number is related to a population which is approximately five times larger than in the Netherlands. As a comparative indication: in cities with 2-3 times more citizens than Amsterdam much more heroin deaths were registered (135 in Berlin and 128 in Hamburg, mainly Germans; versus 13 Dutch heroin deaths in Amsterdam).

29. A comparable trend was found in other field studies. Heroin users in rural areas often bought small dosages of heroin in their home town, and slightly larger dosages in larger towns in the neighborhood. For some grams they would travel 50 miles or more. However, they would seldom go to Amsterdam (Korf et al. 1990). In a region closer to the Dutch capital, we found a larger proportion of users who also bought smaller dosages of heroin in Amsterdam. Public transport facilities appeared to be important: users from towns with good public transportation connections with Amsterdam would buy heroin there more often than those from towns with better connections to the largest town in the region (Korf et al. 1990)

30. For example, in a school survey conducted in a Dutch-German region, it was found that a small group of German students had been offered illicit drugs while in the Netherlands; however, the same survey also showed that several Dutch students had the same experience in Germany (Plomp and Van Oers 1989). 


\title{
VIII. SNACKS, SEX AND SMACK \\ THE ECOLOGY OF THE DRUG TRADE IN THE INNER CITY OF AMSTERDAM
}

\author{
Frank van Gemert and Hans Verbraeck
}

\section{Introduction}

Law enforcement officials, custom agents, academic researchers or people who like to use drugs - in short, people with a more than a verage interest in illegal drugs - tend to strain their ears when hearing the magic word "Amsterdam". Amsterdam, and in particular the old center of the town, is viewed by many as a "dope fiend's paradise". In spite of fierce efforts by the City Council to change the city image, the center of Amsterdam is still known as an area where it is easy to buy illegal drugs. This image is only partially correct; many Amsterdam drug users now simply buy their drugs at their dealer around the corner and no longer go downtown for drugs. Besides, for the somewhat adept drug user it is equally easy to obtain illegal drugs in other Dutch, European and American cities. Yet, for a considerable length of time now, drug dealing has been closely intertwined with the daily reality of the old town center of Amsterdam.

In this Chapter we provide an ethnographic account of drug dealing in downtown Amsterdam from 1970, zeroing in on two streets: the Zeedijk and the Damstraat. It is our purpose to disentangle the modus vivendi in this complex habitat. From our chronological description it will become evident how drug dealing has left a mark on this section of town. We provide the context for understanding the nuisance resulting from the drug trade. In addition to discussing the national and international drug conjuncture, we focus attention on local factors; specifically, we argue that the same informal codes which have characterized the tolerant nature of the neighborhood have also provided the seeds for drug-related nuisance and problems in this area.

In addition to published scholarly and journalistic sources, we rely primarily upon our own data: fieldwork experiences and many conversations with drug users, drug dealers and local residents. The bulk of our fieldwork was done in the second half of the 1980s (Van Gemert 1985, 1987, 1988; Verbraeck 1988). A map of the central Amsterdam area is provided to complement our ethnographic account (Fig. 1). 


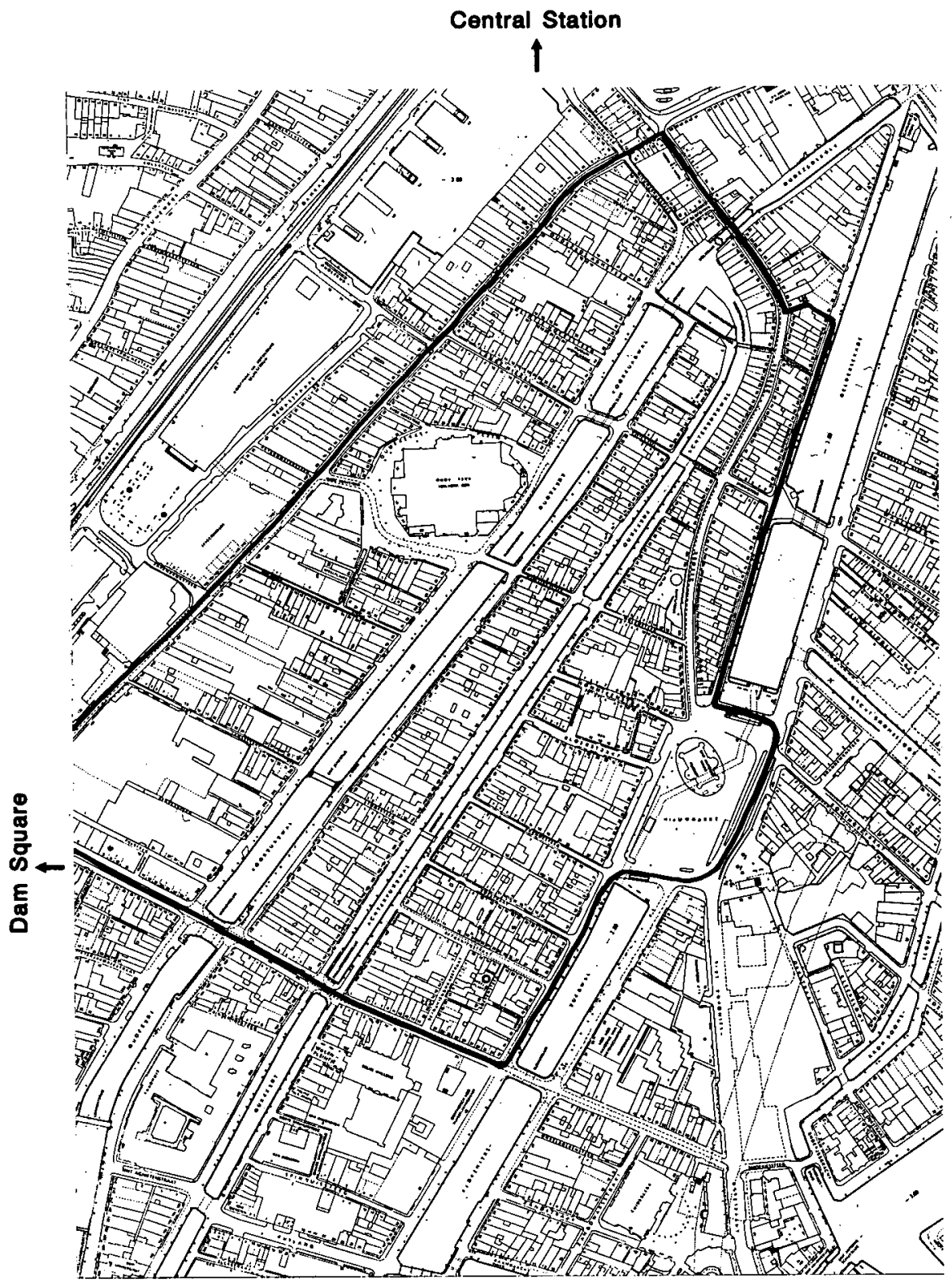

Fig. 1. Map of the central area of Amsterdam ("drugs and prostitution area" within the solid line, scale 1:5000). Reproduced by courtesy of the "Dienst Openbare Werken Amsterdam". 


\section{The history of the old city}

The history of the Amsterdam city center dates back into the Middle Ages. Amsterdam became wealthy through overseas trade. All activities in earlier centuries were closely linked to shipping and trade. The Zeedijk, at present still the most infamous copping street of Europe, was then directly connected to the Amsterdam IJ harbor where the entire sailing world appeared to set foot ashore. A network of narrow streets and alleys, intersected by canals, emerged. Because of its busy harbor, the old town center soon became populated with bars and prostitutes. Still, throughout the centuries this old town center remained a residential area with many small shops and businesses. These small neighborhood stores continue to exist. Residents came from all possible directions. Many population groups exiled from other areas settled there and foreign merchants and sailors also permanently established themselves in Amsterdam. Part of this last category was made up of Chinese who successfully introduced the Chinese food culture to the city during the Depression. The Chinese established their own permanent community in several blocks within the center of town. Not only did they bring a new culinary experience, they simultaneously introduced the smoking of opium to Dutch society. In the Binnenbantammerstraat, between the restaurants and shops, a few opium dens emerged. Unlike the United States, after the introduction of opium legislation (Musto 1973), such opium dens were initially tolerated and were not harassed or abolished.

What exactly triggered the demise of the neighborhood is not clear. In any case, in the course of the 20th century, the Amsterdam harbor continuously became less important and the Second World War gave a serious blow to the neighborhood. Before the war, the Nieuwmarkt neighborhood was $40 \%$ Jewish. In 1942, a section of this neighborhood was made into a "Judenviertel" by the occupying forces and afterwards many Jews were deported. Following the Second World War, the city developed a plan to demolish the deserted and dilapidated streets and to establish a commercial center. However, local residents had different plans; they wanted to keep the neighborhood essentially residential. For about 30 years, city and residents were pre-occupied with the issue of the destination of the neighborhood. Ultimately, the wishes of the residents were realized (Van Breenen et al. 1987; Koster 1987).

The heart of a western city tends to consist of modern business buildings or, conversely, is characterized by large older buildings, reflecting a rich history. Unlike New York or Paris, Amsterdam does not have millions of residents and, thus, the old center of the city resembles in no 
way a major world capital. No enormous buildings, old or new, but a few canals and a maze of streets and alleys packed with houses, seldom counting more than three floors. In the old town center, one finds the grocer and the used book store next to the cafe and the snackbar. Around the corner, there may be a gambling hall and, within a stone's throw, sparsely clad women seated behind the windows, "Hi honey, how about it?" It is in this area, an area which more closely resembles a village rather than a metropolis, where the drug trade, eventually known far across national borders, began to develop.

Initially it was primarily sailors who sought their entertainment in this neighborhood; however, students, intellectuals, artists, jazz musicians and homosexuals gradually began to frequent the area. Consequently, the customers of the opium dens began to change. In addition to the customers who had been coming there for decades (in the Chinese community opium is a common old-age provision), members of the above-mentioned groups also began to experiment with opium. This development, beginning in the 1950s, continued into the next decade. Of course, youths all over the world began to use a variety of drugs during the 1960s (Cohen 1975; Perry 1985). Speed, cannabis, hallucinogens and cocaine now became part of the scene. In the Binnenbantammerstraat, a growing number of users waited daily until a Chinese resident would emerge willing to sell opium for ten guilders per gram.

"I remember the sound of the dice from the gambling house, tens of Chinese standing in the door opening. And myself waiting for the opium den at number 16. Or in front of the den across the street..... The grandfathers were addicted themselves. Very striking types.

It was quite an art to get the drugs, badgering, asking, it did not just happen..... We called him Pepper and Salt because of his hair. From a worn billfold he would get the packet. Was wearing a silk, quilted robe (Verhey 1985:27)."

In the winter of 1971-1972 it became increasingly difficult to obtain opium (Stoute 1985). The production of opium was halted in Turkey, and more and more opium from the Golden Triangle was transformed into heroin (Fromberg et al. 1976).

In the summer of 1972 , there was suddenly an increase in the supply of heroin for sale in Amsterdam, which had been very seldom the case in the late sixties. Young tourists, among them a remarkable number of Americans, easily spent their money on the dirt cheap horse $(\$ 10-\$ 20$ per gram). At that time, drug enforcement agents had other priorities, among 
other things cannabis and opium. Heroin was thus sold very publicly and without any interference in the city, among other places in a few cafes at the Nieuwmarkt. Financial interests appeared non-existent; in the summer of 1972 horse was freely shared and distributed.

The honeymoon, during which the Amsterdam scene became acquainted with the ridiculously cheap heroin, lasted only one year. The police became interested in this particular drug (in 1971 only 50 grams of horse was confiscated; in 1973 this was 23 kilos) and the bars at the Nieuwmarkt where heroin was sold were closed, one by one. The price of heroin increased, the purity decreased, and more and more organized Chinese criminal groups got involved in the trade and imported ever-increasing amounts.

An illustration of the typical criminal group member is provided by Verhey (1985:27). "Hard flashy fellows from Singapore, guys who don't use themselves, golden toothpick in the mouth, pushy."

In the downtown area, the manner of doing drug business changed in order to spread the risks. The Chinese bosses were looking for intermediaries and they found what they were looking for in the young Surinamese immigrants, who came to the Netherlands in large numbers in the second half of the 1970s. They provided an important retail market and belonged to a category who smoked heroin and cocaine by heating a dose on aluminum foil and sucking up the smoke through a straw. From this point in time, the Zeedijk plays a crucial role in the drug trade; in a later stage, the Damstraat also began to emerge as an important area for the drug business.

\section{Drug dealing in the inner city}

Gradually, then, illegal drug dealing became more common in the inner city. Although the illegal drug business maintained an uneasy and tense relationship with the respectable order, it managed to become firmly entrenched in two streets: the Zeedijk and the Damstraat. On the Zeedijk, drug dealing began to overshadow everything else; on the Damstraat, drug dealing took place in the middle of other functions.

\subsection{The Zeedijk}

\subsubsection{Heroin cafes}

Young Surinamese visited the inner city and the South American street corner culture was centered around the bars and nightlife in the Nieuw- 
markt area. They frequented the cafes on the Zeedijk where heroin was sold from behind the counter. These cafes were soon referred to as "heroin cafes". Using and dealing became a daily routine for the immigrants. The sale from the bars at the head of the Zeedijk was left undisturbed in the mid 1970s. By 1978, there were seven heroin cafes in the Zeedijk area, when the police initiated the first actions against these cafes. For a brief period, the Surinamese dealers and their customers were chased away from the Zeedijk. They came adrift, taking over a Surinamese social service agency which was consequently closed, forcing them to move through the city from one cafe to the next. At the local level, the Zeedijk lost its prominent drug trade position. During the time that the Surinamese dealers and their customers moved through the city, drugs were sold more and more from private homes. Only a small group of users, consisting primarily of Surinamese users, was not able to find a steady address for buying drugs. After a while, this group returned to the Zeedijk. The number of cafes where dealing took place rapidly increased to about 30 establishments in the entire street by 1981. Now Chinese intermediaries and Surinamese were fighting for dominance on the Zeedijk. Before the Chinese intermediaries completely disappeared from the retail trade, the street was split up: the Surinamese dealt in one section of the Zeedijk (from the head to the Stormsteeg) and the Chinese in another (from the Stormsteeg to the Nieuwmarkt).

The heroin cafes were usually Surinamese family businesses. One person, the head of the enterprise, was in charge of buying the drugs, while about every six months new sales people were hired to replace the old ones. Dealing from such establishments was conducted with a maximum concern for safety. Outside, people on the lookout warned those inside by pounding on the rain pipes whenever they saw potential trouble. Because only a little dope was kept in the house and because often there were hidden food elevators and secret exits, it was virtually impossible for the police to find contraband. This allowed such establishments to remain virtually impregnable vestiges.

Ordinary citizens began to avoid this street because of its sinister atmosphere. Those passers-by who were lost, were invariably "vacuumcleaned" on the Zeedijk: robbed of money, cameras, and jewelry. Meanwhile, the police obtained authority to close those cafes where dealing took place; however, this measure had a limited effect since an evicted dealer was easily able to find another location to continue his business. Property owners realized that there was only one type of renter left on the Zeedijk - the drug dealer with a large amount of money. A rent of 1,200 guilders (some $\$ 600$; half of that amount would be considered high 
under normal circumstances) was paid without any problem for a simple apartment; if it were not for the drug money, such a high rent would not have been affordable. It was not until the city gained control over the distribution of housing and began to systematically purchase the properties that such retail locations disappeared. Drug dealing increasingly began to take place in the streets; and the system of Surinamese familyrun heroin cafes collapsed.

In that period, the bulk of the heroin in Amsterdam came from the Golden Triangle, but by the end of the 1970s another type of heroin was introduced into the local market place. At a high level in the heroin trade a war was fought between Chinese dealers from Singapore and Chinese dealers from Hong Kong. Afterwards, a second connection increased in importance; Turkish organized crime started to import increasing amounts of very potent horse from Pakistan. In contrast to earlier years, heroin was transported primarily over land with cities in Middle Europe gaining increased importance as distribution centers. Amsterdam retreated somewhat to the background of the drug distribution scene. At the same time, low-threshold methadone maintenance programs were implemented in Amsterdam and several other Dutch cities. Users applied for these programs in large numbers. Although many had already experimented with other drugs, the introduction of methadone programs resulted in the increased importance of cocaine and other psychopharmaceutical drugs in the inner city. In addition, alcohol received a more dominant position on the menu of the user.

\subsubsection{Street trade}

The strategy of street dealing was quite different from the strategy used in the heroin cafes. Some street dealers operated individually and protected their safety merely through a few places on the street where they hid their goods. They approached potential customers themselves. Other dealers worked on a larger scale; they decided to spread the risk and hired assistants - several people who sold drugs, one person who kept his drug supplies and another who safeguarded his money. They also hired "messenger boys" who were continuously on the lookout for potential customers, whom they sent to a dealer or his agent in exchange for drugs or money. Occasionally a person was hired as a lookout. As compensation he would receive drugs, provided he did his job well. The dealer himself simply observed the trading without any visible involvement.

Although the Zeedijk was seriously decaying, Amsterdam residents 
continued to reside there and a part of the neighborhood infrastructure remained intact. The butcher, the fishmonger, the grocer, the "normal" cafes remained, as did the Chinese restaurants and shops. In the early 1980 s, the city in conjunction with the business community developed a plan to restore the century-old buildings for use by new shops, businesses and residents. As a result, in the second half of the 1980s, there were several buildings in scaffolds and the area was buzzing with construction and renovation activity.

Along with the economic restoration projects the police were also given more legal power to intervene in drug-related activities. The city took several administrative emergency measures primarily geared towards dealing with the problems on the Zeedijk. A "no knives" ordinance was implemented in 1981. Other local ordinances authorized the police to prohibit individuals or groups from assembling (1984) or from entering the area for a certain time period (1983). Furthermore, the police expanded its surveillance significantly. A special police team was established, the "local unit", which focused exclusively on street dealing; additional police officers and undercover agents began to patrol the Zeedijk area. Mounted police and police officers with dogs appeared. In 1985 a special Zeedijk team was established and in 1987 (the year of our most intensive fieldwork in the area) no fewer than six police officers were on patrol 24 hours a day on the Zeedijk - a street no more than 500 feet long! The battle between the scene and the police was grim and sometimes resulted in chaotic scenes:

"The corner of the Zeedijk and the. Molensteeg is crowded, here are at least $\mathbf{5 0}$ users and dealers. A police van drives by. The first time it passes by, a part of the group simply stays. When they do not obey the request to move, one of the officers gets out with a German shepherd dog. A peculiar parade then develops: a big wave of users and dealers who quickly make a few more deals, behind them the police officer with the dog and finally the van with the barred windows. When the van passes by for the second time, the corner area begins to fill up again. This catand-mouse game is repeated three more times before the users and dealers finally retreat to the Nieuwmarkt."

Although the reader would perhaps expect differently after reading the foregoing account, the battle on the Zeedijk is not over yet. Even as this is written, a lively drug trade continues; one can hear people advertising their merchandise while scanning things like "big and small brown" (referring to consumer doses of heroin of $\$ 20$ and $\$ 10$ ) and "big and small 
white" (doses of cocaine at the same prices). The dealers who stay around in the neighborhood continuously adjust their strategies. Presently, anybody passing through the Zeedijk area will see a very conspicuous, public and drab tip of the iceberg of heroin dealing and heroin using Amsterdam: a continuously shrinking, yet unceasingly problematic remaining group of street junkies and dealers continue their daily presence in the inner city.

\subsection{The Damstraat}

\subsubsection{Street dealers, house dealers and messenger boys}

In contrast to the Zeedijk which has always been a noisy "party" street, the Damstraat is characterized more as a shopping street. Beginning at Dam square, the street provides an important pedestrian connection to the Stopera (city hall and opera under one roof). Many pedestrians, in particular tourists, are "sucked into" this street, either by design or by coincidence.

Even in the 1970s visitors bought their hash from street dealers in the Damstraat. These dealers earned gold during the vacation periods. They approached every potential buyer muttering the words "hash, hash". Several restaurant and bar managers realized that they could attract more customers by allowing people to "smoke" in their establishment. Not surprisingly, drug dealers also started to hang out in these places. Trying to prevent all drug dealing required enormous effort by the management of these establishments. After a while it became clear that some businesses had made a virtue of necessity. No longer did they resist cannabis dealing; instead, they began to actively participate in it.

This introduced a novel phenomenon: coffee shops where one could buy hash. Around 1980 there were only about four such coffee shops, however this number has expanded explosively since then. The growth has been so tremendous that presently, for many Amsterdam locals, the first thing that comes to mind with the word "coffee shop" is marihuana, not coffee.

The users preferred to buy in a quiet coffee shop, where one did not need to be on the constant look out for the police. Furthermore, they soon realized that the chance of buying furniture polish or other fake hash was considerably smaller in a coffee shop than on the streets.

In these establishments, the management usually appointed one person who was the only person authorized to sell hash and weed. As a rule, the management took care of the drug supply. Particularly in the early days 
of the coffee shop, this "house dealer" was presumed to conduct business with the utmost caution. However, once it was realized that dealing in these places was left virtually undisturbed, more publicity became the rule. One advertised in the local paper and the coffee shops were easily recognizable by the large marihuana leaves on the windows. Selling no longer occurred in secret. It used to be typical that a customer would discretely ask for the house dealer and then proceed to buy inconspicuously a small packet from this house dealer, who "just happened to be there". At present, customers simply walk up to the counter and ask what is for sale. Either they are shown the different types or they are referred to the "menu" which is clearly visible hanging on the wall.

In November 1987, when a few of the coffee shops experienced taxrelated trouble and it was announced that strict measures would be taken against public advertising of the hash business, a shock reverberated throughout the world of the coffee shops. The marihuana leaves were removed from the windows or hidden behind stickers, but soon it was business as usual when there was absolutely no evidence of a mass persecution.

By the mid 1980s, hash was only seldom sold on the streets. The street dealers lost the competition with the house dealers in the coffee shops. Thus, those people who used to deal in hash on the streets were forced to start selling other drugs or to stop street dealing completely. This resulted in a separation of the drugs market.

"Two dealers who for years on end had only sold hash, disappeared from the streets and started to concentrate on growing "Netherweed". Both of these men presently supply several Amsterdam coffee shops with this drug. Thus, although they turned their backs on street dealing, they have remained faithful to their line of business."

While the hash trade continued from the coffee shops, the dealing in hard drugs flourished on the streets. It remained primarily the tourists who provided the market for these drugs. Due to the changed nature of their merchandise, the dealers were now guilty of more serious offenses than before. Moreover, one was no longer limited to selling one type of drug. The successful dealer had to be able to supply several drugs at short notice. As a result, the street dealers began to work with messenger boys, who operated basically in the same fashion as their counterparts on the Zeedijk.

Only the more reckless street dealers remained active. The newcomers were also willing to take greater risks, resulting in a changed composi- 
tion of this group. Initially it was mostly Dutch hash smokers who tried to sell their beloved "Libanon, Afghan or Marok", but later there was a growing number of addicts who also attempted to get rid of horse and coke. Most of them, however, had empty pockets and hoped to find customers as messenger boys. This group included an increasing number of foreign people. "Ripping off" increased and street dealing developed a bad reputation. The street was no longer "respectable" for dealing in hard drugs. Although Dutch users still buy their horse and coke mainly on the Zeedijk or from private addresses, buyers in the Damstraat are usually, at most, only two handshakes away from a person who can supply a considerable dose of any desired drug.

\subsubsection{Pill trade}

During the summer of 1985 as the newly established Zeedijk police team began to enforce the law in a more stringent fashion, several Dutch users moved to the Damstraat. Near the bridge at the Oudezijds Achterburgwal, a meeting place was established for predominantly older heroin users. Typically, passers-by felt pity for them and there was virtually no initial objection to their increasingly conspicuous presence. Gradually, more "sick" users came to this meeting point. There was always somebody among those present who was willing to sell a few methadon pills. Starting in the summer of 1986 , this bridge was commonly referred to as the "Pill Bridge". More and more people were attracted by the pill dealing. Not only "sick" addicts came here, but also a growing number of dealers took advantage of this readily available market. Dependent upon the presence of the law, they praised their merchandise in loud or subdued voices: "Metha", or "Rooie Knol" - a Dutch version of the sleeping pill called Rohypnol. Such transactions took place on the streets with little effort to conceal business. The pills were counted out in the hand of the buyer who paid in cash. In this manner, every addict who received methadone in pill form could thus sell his own dose. As soon as they were rid of their pills, the addicts would no longer hang around at the bridge, rather they would disappear in the direction of a horse dealer at the Zeedijk. Often the person who had sold methadone earlier would get in trouble himself a few days later and rush to the bridge to take his turn buying methadone pills. This short-term planning and the small profit margins resulted in a relatively low status of those involved in selling pills. Among those involved in the drug scene were the pill sellers; one does not speak of "pill dealers" - a term which provides a certain amount of status - but rather of "pill sellers". Pill sellers were not afraid to be 
picked up by the police; it involved only minor violations and they would be released very quickly again. Consequently, for a number of years, this trade was very visible in the Damstraat. More recently, however, it seems that the selling of pills has moved somewhat underground as a result of renewed intensive police intervention.

\subsection{The Zeedijk and the Damstraat: Drug monoculture vs transitional zone}

The shopkeepers who refused to leave the Zeedijk were forced to accept the conspicuous presence of the illegal drug business. The visitors of the street were nearly always involved with drugs. If one were to refuse them as customers, many of the shops would no longer have been profitable. Many shopkeepers compensated for their loss in revenue by fencing stolen goods or by subletting their building. Slowly but surely the respectable order on the Zeedijk disappeared in the monoculture of drug dealing.

On the other hand, the Damstraat continues to serve functions other than illegal drug dealing; it provides a transitional zone between the dominant culture and the culture of drug dealing. In this street, young tourists are customers of both shops, restaurants, bars and drug dealers. Snackbars, headshops, $t$-shirt shops, cafes and coffee shops are legitimate enterprises, however, they do profit from the appeal of the drug culture. This transitional zone has the advantage that the drug user is able to obtain illegal drugs without being stigmatized. After all, both (legitimate) shopping and buying (illegal) drugs are plausible activities in this area. This explains why novice users or users from out of town are mainly found in this street.

\subsubsection{Neighborhood nuisance}

By the early 1970 s, Amsterdam had become a mecca for students, tourists and dropouts; the National Monument at the Dam square became a popular gathering place for hash-smoking "hippies". In 1971, members of the Royal Dutch Navy, upon their own initiative, and with a great show of force, attempted to remove these hippies from the square. Without a doubt, this action was an unambiguous expression of disapproval of the non-conformism of these so-called "dam sleepers". Although this action took place in the inner city, it was neither initiated nor supported by the local residents. At that time, there were virtually no feelings of nuisance caused by drug using or drug dealing in the neigh- 
borhood. A great deal of time passed before the tolerant attitude of the neighborhood was transformed into protest.

"A restaurant manager in the Zeedijk area scrubbed his sidewalk every day during the 1970s. A few times a day he stood in front of his door with a baseball bat and on a regular basis he used this weapon to refuse admittance to members of the scene. It was the consensus of the other people in the neighborhood that this was going too far and he encountered a wall of misunderstanding."

\subsection{The Zeedijk}

Initially, the nuisance associated with the heroin cafes remained limited. Throughout the 1970 s, occasional police actions against such establishments were not the results of local complaints, but were mainly inspired by the fact that the Dutch Opium Act contained severe penalties for heroin, the main drug on the Zeedijk at that time.

Local complaints and protests gained momentum, however, when the scene - after making many detours through the city - returned to the Zeedijk and drug dealing on the street increased substantially. In earlier days, local business made money from the rough sailors (sex and booze), but now it was mostly the dealers who profited from the daily visitors to the Zeedijk. The revival of the heroin trade mainly harmed the residents of the northern section of the Zeedijk. They felt that the boundaries of tolerance had been crossed and they organized themselves in the Crisis Committee Zeedijk. However, the Zeedijk residents who lived closer to the Nieuwmarkt were not yet ready for mobilization into action (see next paragraph). In the Fall of 1981, the Crisis Committee Zeedijk distributed posters with a cynical text. Some time later, these angry locals occupied the council chamber in City Hall during a city council meeting; in protest, they threw fake heroin (detergent) and needles all over the place.

The number of businesses selling drugs grew and now virtually all residents had some unpleasant experience with the drug scene. A drug monoculture developed. The shopkeepers lost most of their income and street robbery occurred frequently. The problem at the head of the Zeedijk now became a problem for a large part of the neighborhood, thus causing solidarity to grow. A neighborhood committee, called "The Old Town", was organized. This committee included several leftist academicians and functioned as a tolerant mouth-piece for the neighborhood; for example, the distribution of heroin was proposed as a possible solution. Taking up the national discussion concerning this, they explicitly asked 
for government distribution of heroin. In the view of the neighborhood, the users were sick. Voices also argued in favor of creating "sanctuaries" for users: carefully selected places where people could use hard drugs without interference by the police.

Distribution of heroin never became a reality. Yet, an important point is that local policy was not aimed only at maintaining public order; there was also much concern with the well-being of addicts. With explicit approval of the neighborhood, treatment and assistance played an important role in the approach to the drug problem.

When the economic restoration plan Zeedijk began to take shape and most of the drug distribution locations were closed, numerous buildings were targeted for extensive restoration work. The street acquired a desolate character, which not in the least affected the drug street trade.

In 1984, the "junkboat" (a sanctuary for addicts) was closed, resulting in a growing presence of addicts on the Zeedijk. It was at this moment that the neighborhood, for the very first time, initiated plans to use force against the scene. City Hall responded by instructing the newly established police team to rid the Zeedijk area of addicts. The addicts dispersed throughout the inner city, but when it became obvious that the police action was only a temporary effort, the scene returned to the Zeedijk. Meanwhile, the viewpoints hardened and the addicts became criminals in the eyes of many local residents.

\subsection{The Damstraat}

During the same period, the shopkeepers in the Damstraat complained bitterly about the decay of their street. During the many meetings of the association of shopkeepers and at neighborhood meetings (where often the police were also represented) it became obvious that public confidence in official measures had been reduced to nil. Trying to get rid of shabbily dressed junkies in front of one's windows had become a daily routine.

"On May 21 1985, angry neighborhood residents hung posters with pictures of needles all over City Hall. The text, "Amsterdam's got 'it" used by the city to emphasize the appeal of the city, changed to "Amsterdam has had it".

"In September 1985, the residents of the Damstraat protest, somewhat playfully, against the presence of a group of junkies. They retrieve old bicycle wrecks from the canals and use these to barricade the bench on 
the Pill Bridge. However, by the next day, the now quite popular cry of "Metha, methadon" can be heard all over again."

It was not only the junkies who gave the inner city a bad name. The "ball ball" game (a variant of the three card game), duping hundreds of ignorant passers-by, was also a thorn in the side of the neighborhood. Characters involved in this game were considerably more capable in defending themselves than the junkies. Some shopkeepers were prepared to chase addicts away; however, upsetting the gambling criminals was an entirely different story. Before any steps against the "ball ball" game were taken, cries of distress were heard repeatedly in the national newspapers.

"The "ball ball" game is very often played in front of a particular cafe in the Damstraat. The gamblers do not honor the barkeeper's request to move to another spot. In early June 1986, two large flower boxes appear in front of the business. The game is now played somewhere else. Very soon it becomes apparent that wire-netting has to be installed over the boxes, as passers-by express their appreciation by taking the plants."

In November 1986, city government provided a permit to place a fritter stand on the Pill Bridge, precisely on the spot where the junkies tended to sit. Mysteriously, at the same time, a person appeared whose job consisted of trying to get rid of the addicts. This person was also of questionable reputation; and initially it was not clear who paid his salary. Very soon, however, it became apparent that a number of neighborhood shopkeepers had been reaching into their wallets to pay this person. Although the "bouncer" had no legal authority, he threatened with violence and, occasionally, he suited his action to his word. The simple result was that the pill family moved less than one hundred meters to the next bridge.

When it became clear that other shopkeepers now ended up with junkies in front of their door, it was decided to hire a few more "dumb muscle men". In February 1987, following the example of the fritter stand, a candy stand was set up on the bridge over the Oudezijds Voorburgwal - the bridge that functioned as a meeting place for addicts. In March 1987, a few muscle men appeared; thus, the junkies moved to the bridge over the Kloveniersburgwal - their last station for now. Meanwhile, one thing was becoming very clear: the addicts would not disappear, but only move to another spot. Although in November 1987, a hamburger stand was placed here, this third bridge has remained the place 
where pills are sold.

These developments received extra attention in the summer of 1987 due to citizen disapproval of a wave of publications concerning Rohypnol, a sleeping pill sold daily on the Pill Bridge. It was claimed that the most horrible crimes had been committed under the influence of this drug; soccer vandals, allegedly, had also discovered it. Temporarily it seemed as if a new criminal drug problem presented itself in the Netherlands which resulted in deliberations in parliament to take this product out of circulation. However, because this pill is not essentially different from other benzodiazepines, one soon realized that this would only be a spurious solution to the problem.

"For several days in the Spring of 1987, a few neighborhood residents collected the wrappings of the pills sold on the bridge.

Because the names of the users were printed on the boxes, it could be determined, without question, that the pills came from the drug-assistance programs."

Paralleling developments on the Zeedijk, all residents and shopkeepers of the Damstraat were now convinced of the gravity of the situation. At this moment, for the first time, actions were not only possible; they were also supported by the entire inner city. At different meetings the neighborhood vocalized its demands, and the city agreed to implement the "Summer Plan". The Summer Plan (implemented between April and September of 1987 in downtown Amsterdam) involved an increased police presence on the streets and more enforcement against illegal drug trade. The priority of police drug policy was to maintain public order. The catand-mouse game became more grim and thus the "dealers guild" more alert.

"Details of the appearance of the undercover police officers made it possible to determine their identity irrefutably. Because undercover officers never patrolled on a bike, it appeared a smart move to start using bicycles. However, service bicycles in perfect condition are very conspicuous in the city center, even with an undercover police officer instead of an officer in uniform. That is why the dealers easily recognized these officers. After a while, they started to use older bikes."

After the 1987 summer period, the police force was reduced to its former size and according to many, the situation remained essentially the same, except, perhaps, that the junkies had become more mobile. They 
now covered a larger territory; those who were formerly only active on the Zeedijk were now also found in the Damstraat.

In October 1988, the neighborhood once again expressed its displeasure with the city. It was said that, although police were willing to act, their hands were tied. Consequently, an administrative solution to the problem was demanded. The tolerant position had now definitely disappeared; the neighborhood committee, "The Old Town", rejected its former position and turned forcefully against drug use and trade in the area. A large number of area residents and shopkeepers assembled and a long parade, armed with banners, went directly to City Hall. En route, the group was joined by several classes of school children, a group from a nursing home and a delegation from the Chinese business community.

"Between familiar faces of shopkeepers, bar managers and women from the neighborhood, I also saw one which amazed me tremendously, "German Hans", a hash and coke dealer and a more-than-average user, walked with a sign saying "We don't take it anymore". Later I heard that he had opened a coffee shop close to the Nieuwmarkt."

On foot, the parade progressed to City Hall to a city council meeting which had the drug problem on its agenda. Once in the council chamber, the parties involved expressed their discontent until everything became so disorderly that the meeting was adjourned.

Two weeks later, the neighborhood once again felt the need to emphasize its demands. During rush hour one evening, a blockade of burning car tires was set up at the Prins Hendrikkade. There were no further incidents, but traffic was completely stalled for two hours.

Thus, public feelings of nuisance increased and the government apparently was not able to respond efficiently and effectively to this problem. It is commonly assumed that public annoyance is a direct result of drug use and drug dealing. To a degree this is true; however, one cannot help wondering how it was possible for the drug trade to become so firmly entrenched in the city center in the first place. It is our hypothesis that local behavior codes provided an important and fertile ground for the drug trade, which is why the neighborhood needs to take some responsibility for its own problems.

\section{Codes, crime and crisis}

It may be argued that the proverbial Amsterdam tolerance originated in its central downtown area. A number of free spirits played a vital part 
in this process.

"In the middle of this century, Bet van Beeren was the queen of the Zeedijk. In cafe "Het Mandje" which she managed, everybody was welcome, not in the least homosexuals of both sexes. If intimate scenes threatened to be witnessed by the wrong eyes, Bet gave a warning. Even before the spoilsport entered, everybody was informed."

"Zwarte Joop" was born in the neighborhood and his career started with the illegal showing of pornographic movies in a small theater. In the 1970 s and 1980s, this self-made man owned a sex and gambling empire at the Walls. He himself established a security service to ensure a smooth visit for those who entered his business. Virtually everybody, including the police, overlooked the occasional use of violence.

"About eight men were stationed at each bridge and everybody who dealt (drugs) was beaten up. Everybody who was black and out on the street after two o'clock was thrown into the canal. Once this group pursued a Surinamese who had knifed a Swede, all the way to the Oudekerksplein, like a kind of posse, and then proceeded to break his nose with a baseball bat. The next day, police chief Nicaise paid a visit to Joop to ask if he could lay off a little" (Middelburg 1988:162).

"Joop died on July 13, 1986. His empire was about to collapse due to large tax debts and in December 1983, a large part of his nightclub was reduced to ashes because of a revenge-motivated arson."

Although both their activities went against respectable order, both Zwarte Joop and Bet van Beeren were celebrated people in the neighborhood. Both were bending the rules, but not only to their own benefit. Many bars attracted extra customers since the city center allowed homosexuals the opportunity to move around freely, and safety in the neighborhood was more important for local residents than the fact that the police did not have the monopoly on the use of force.

People who elsewhere would have been damned, taunted, or barred, thus found a supportive environment for their practices in the inner city of Amsterdam. That is why this area, for a long time, housed a colorful collection of non-conformists who, attracted by the tolerant climate, live in a symbiotic relationship with the other locals residents. How may we explain this? Are the rules different in this area? We have already shown that it is possible to break the law without violating the codes of the neighborhood. The opposite, however, is also possible. 
"In early September 1986 , a souvenir shop on the Zeedijk and a barbershop a few streets away were vandalized and occupied by neighborhood residents. This was a protest against the sale of drug paraphernalia from these premises (needles for $\$ 1.25$; a quarter of a lemon, indispensable to dissolve Pakistan heroin, and pieces of tin-foil, both for $\$ 0.50)$ )..... The barber relented and gave up the sale of drug paraphernalia; however, the legal sale of needles from the souvenir shop was only briefly interrupted by the neighborhood action and continues until this day. In this manner, the manager of this shop has isolated himself permanently from the rest of the neighborhood."

What is considered right or wrong by the neighborhood and what has been described by law as such are not necessarily one and the same. In addition to this substantive difference, legal codes tend to have unambiguous boundaries, while neighborhood codes know more gradual distinctions. The already-mentioned "ball ball" game is a case in point.

"As early as 1980 a few Yugoslavs played the "ball ball" game at the Walls and near the Oudemanhuispoort. The gambling game drew attention, but was only occasionally played in the summer. In 1985, a few Moroccan boys show up in the Damstraat who introduced the game again. They made good money, but they were not able to deal with unhappy losers."

"Therefore they came to an agreement with several Dutch criminals who participated in the game and who, if necessary, used force to protect the profits. Because of the profits and the limited resistance encountered, the players became reckless and more and more unsavory situations developed: traffic jams, fights and arrogant behavior with the large amounts of money."

In 1988, the police received permission to deal more harshly with the participants. The game is no longer played in Amsterdam. In principle, there was little resistance to this illegal gambling game; however, as it began to occur on a large scale and began to dominate the street, considerable opposition developed. As opposed to those who had introduced it, the newcomers used the game in an excessive fashion, thus offending residents of the neighborhood.

What do the codes of the inner city entail? What is allowed and what is not? We may distinguish three criteria. First, it is important that there is not an unacceptable amount of neighborhood nuisance and disturbance associated with the activity. Second, the situation is affected by whether 
there are recognizable victims. It is no coincidence that "permissible" deviant behavior primarily centers around "crimes without victims": gambling, drugs, sex, fencing. A third criterion is that it has to involve activities that can also be carried out by non-offenders. Thus, the nature of the violations does not result in the stigmatization of the offender and the social removal of the offender from the non-offenders. Fencing, in particular, is closely intertwined with the everyday realities of the inner city, and many cannot stop themselves from taking advantage of stolen goods.

"In a downtown cafe, virtually every day drug addicts come by to offer stolen goods for sale. To prevent confusion, the names of the two "salesmen", both named Peter, received an addition referring to their specialty: Peter "Bike" and Peter "Book"."

That dealing in soft drugs also takes place within the reach of the ordinary citizen becomes apparent from the following reflections by a bar manager:

"All day I tried to keep the street dealers out. I had become a thief from my own wallet. On the street everything was sold, the police did nothing. And I kept on trying to keep my business clean. Frequently, Germans came in and asked for 20 grams or an ounce, but also a pound or a kilo! Then I decided to get a house dealer..."

"Snitches" are very unpopular here. Most people are reluctant to report violations, particularly if they themselves were not victimized. This reluctance to report occurs mainly because of the frequent interchangeability of offender, victim, and witness roles: the next time they might be the offender and need to count on the discretion of others. Snitching is not likely to result in violent sanctions. Although the Amsterdam criminal milieu does know liquidations: lethal revenge would be considered definitely inappropriate by all parties at this particular level of interaction.

All of these factors make it extraordinarily difficult to catch an offender. Initially, the inner city had its own regulatory system, ensuring that things prohibited by law did not cause any nuisance to the neighborhood. Both the individual and the neighborhood profited from these law violations. When the neighborhood began to resist because of the nuisance mainly caused by drugs, this symbiotic relationship was transformed into parasitism. Nowadays it is still acceptable that a person slips into the role of an illegal or semi-illegal profit seeker every once in a 
while, but the interests of the individual and the neighborhood no longer coincide. Among the many cafes in the city center, several are doing very poorly. When a dealer becomes a good customer of a cafe and one then discovers later what the nature of his profession is, it is very hard to get rid of him. Bartenders are "convinced" by a big tip and many employees are bought with a sample of hash or coke. Different from the earlier days, when this kind of thing took place outside the reach of the police and appeared beneficial to the neighborhood, these law violations seem to have mostly negative consequences for this community. Still, most area residents do not want to be a traitor and it remains very difficult for the police to arrest offenders. Moreover, the form in which the current parasitism manifests itself has changed and this suggests that, perhaps, there is an even more subtle and closer interconnection between the legitimate and illegitimate domains than before.

"At the corner of the Lange Niezel it was very dark for years because the building was empty. In front of the door, addicted prostitutes hung around 24 hours a day. Many residents breathed a sigh of relief when they heard that a big snackbar would be established there. From the start, however, it became obvious that this business would be a meeting place for whores and their customers, their addicted boyfriends and numerous users and dealers. It goes without saying that they represented the biggest market for the fast food."

"The stands that were placed on the bridges in the Damstraat found their customers among the very population that was to be removed from this particular area. The fritters and the sweets from the candy stand fit perfectly in the daily menu of the junkies hanging around in this street. A foreign drug expert sincerely inquired whether these stands were put there to accommodate the scene."

"Whenever possible I walk by McDonalds, for their straws are the best to chase the dragon", a Surinamese user stated.

\section{Conclusion}

For centuries, the Amsterdam inner city has been a tough neighborhood. In addition to the fast food culture, prostitution and gambling, drug dealing also has become firmly entrenched in this area. We have described the development of the drug business in two Amsterdam inner city streets from 1970 to the present. 
On the Zeedijk, heroin dealing initially took place in the cafes and continued on the street after the police intervened. The family structure that existed in the cafes was replaced by individual dealers and dealers with assistants. During the second half of the 1980 s the police began to act with increasing force against the drug trade and the dealers had to hire a growing number of helpers to practice their profession efficiently.

In the Damstraat, from the early 1970s, hash had been offered to young tourists. When the sale of cannabis was transferred to the coffee shops, the street business took on another character. Hard drugs were now for sale and dealers also began using helpers. In this street, during the second half of the $1980 \mathrm{~s}$, a lively pill trade developed involving a large number of users who took turns as buyers or sellers.

Up until the early 1980s, virtually no nuisance was caused by drugs in downtown Amsterdam. This changed, however, when a clearly recognizable group of addicts (a group which incidentally continued to get smaller in size) became increasingly conspicuous outside the Zeedijk. Protests from the neighborhood were initially quite playful and not well organized. Gradually, however, neighborhood actions became better organized, more extensive and harsher. Local authorities responded with extended police powers, more police patrol, and an economic restoration plan for the affected Zeedijk area.

Because of these developments, the inner city of Amsterdam is no longer a dope fiend's paradise for the street scene. Present users increasingly view the normalization policy of Dutch government as a tight strait-jacket; this notwithstanding the easily available needles and methadone. The efforts of city government have caused a number of the dealers and users to continue their daily business somewhere else. Yet, until the present day, there remain many people in downtown Amsterdam who earn their money from drug dealing. They are easily recognizable (also by the non-initiated out-of-towner) and they determine for a significant part the image of the city center.

The persistent nuisance associated with drug use and dealing in illegal drugs is only partly a result of the local, national and international drug conjuncture. The ambiguous attitude among many with regard to petty illegal and semi-illegal advantages were (and continue to be) a fertile ground for illegal behavior. In the past, the excesses of this flexible moral stayed within acceptable boundaries and formed an essential component of the tolerant climate of the inner city. The individual could benefit without being too costly for society; the community profited from the illegal drug trade. Gradually, this symbiosis changed into parasitism because individuals began to pursue personal profit with little or no con- 
cern for the resulting problems within the neighborhood. Through this process, the benefits of drug-related activities are increasingly overshadowed by the resulting nuisance and disturbance of the local habitat.

\section{References}

Cohen, H.: Drugs, Druggebruikers en Drugs-scene. Alphen a/d Rijn: Samson, 1975

Fromberg, E., Kalkhoven, S., Haverkamp, G., Steegers, J. and De Jong, T.: Stichting Kontakt Sentra, Verslag over 1975 en 1976. Amsterdam, 1976

Koster, L.: Wandelaars in de Nieuwmarktbuurt; een Onderzoek naar de Invloed van de Harddrugsscene op het Wonen in een Oude Binnenstadsbuurt. Amsterdam: Instituut voor Sociale Geografie, Universiteit van Amsterdam, 1987

Middelburg, B.: De Mafia in Amsterdam. Amsterdam: de Arbeiderspers, 1988

Musto, D.F.: The American Disease; Origins of Narcotic Control. New Haven: Yale University Press, 1973

Perry, Ch.: The Haight Ashbury, a History. New York: Vintage Books, 1985

Stoute, R.: Uit het Achterland. Amsterdam: de Arbeiderspers, 1985

Van Breenen, K., Dijkstra, H., Van Erkel, F., Jeager, E., De Jong, J., Mulder, C., Rekers, A. and Verwaaijen, J.: De Zeedijk, Nieuw Elan Oude Problemen; Samenwerking tussen Gemeente en Bedrijfsleven als Wondermiddel. Amsterdam: Studiegroep Stedelijke Revitalisering, Instituut voor Sociale Geografie, Universiteit van Amsterdam, 1987

Van Gemert, F.: Pushen, Rippen en Versnijden; Dealers in de Amsterdamse Binnenstad. Doctoraal scriptie. Amsterdam: Antropologisch Sociologisch Centrum, Universiteit van Amsterdam, 1985

Van Gemert, F.: Pallina, Pallina (Ball, Ball). La Strada 11(15):4-7, 1987

Van Gemert, F.: Mazen en Netwerken; de Invloed van Beleid op de Drugshandel in twee Straten in de Amsterdamse Binnenstad. Amsterdam: Instituut voor Sociale Geografie, Universiteit van Amsterdam, 1988

Verbraeck, H.: De Staart van de Zeedijk; een Bliksemonderzoek naar enkele Effecten van het Zomerplan 1987 in het Wallengebied. Amsterdam: Instituut voor Sociale Geografie, Universiteit van Amsterdam, 1988

Verhey, E.: De Binnenbantammerstraat. Vrij Nederland 14-11-1985, pp 2-25, 1985 